\section{orin}

OAK RIDGE NATIONAL LABORATORY
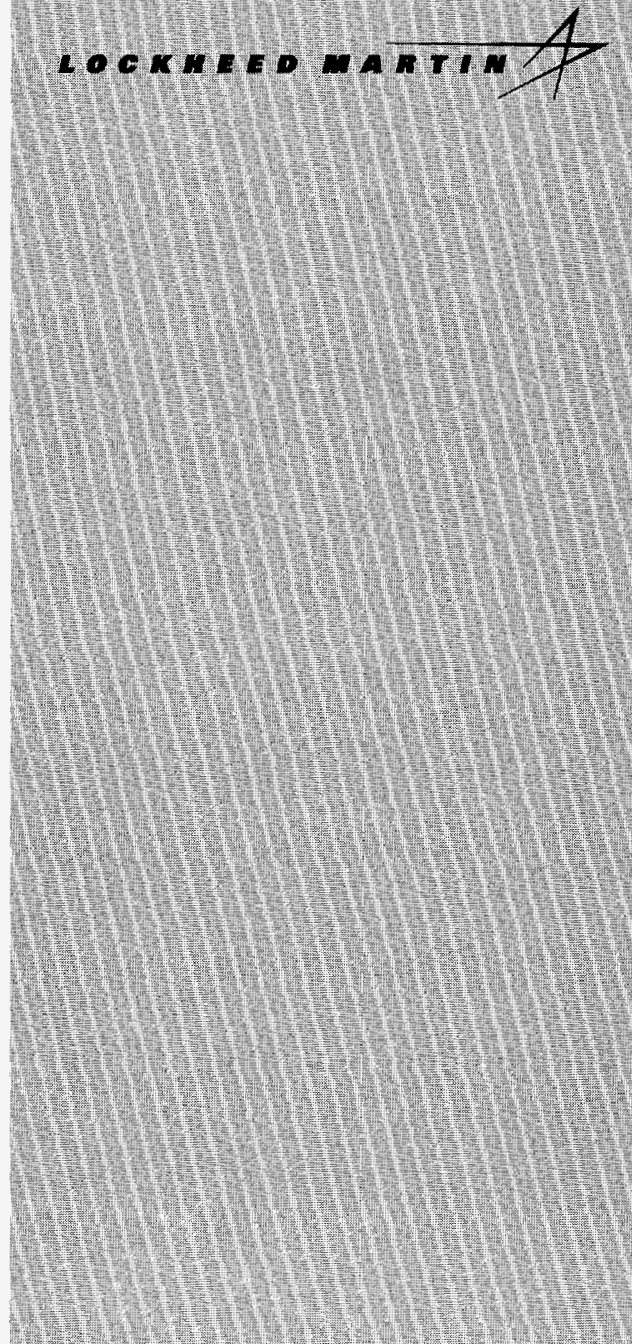

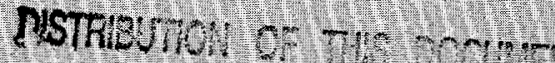

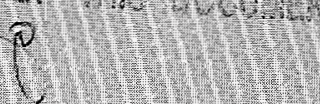

MANAGED AND OPERATED BY LOCKHEED WARTIN ENERGY RESEARCH CORPORATON FOR THE UNTED STATES DEPARTMENT OF ENEROY
LIGHTWEIGHT COMPOSITE

FINAL REPORT

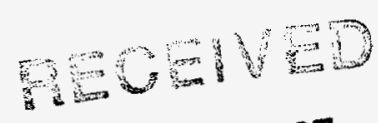

\section{FIGHTING COVER \\ PROTOTYPE DEVELOPMENT PROGRAM}

FINAL REPORT

$$
\text { OSTI }
$$$$
\text { JAN } 29 \text { 1937 }
$$
JAN 29 1397

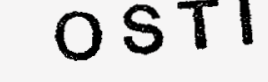




\section{DISCLAIMER}

This report was prepared as an account of work sponsored by an agency of the United States Government. Neither the United States Government nor any agency thereof, nor any of their employees, makes any warranty, express or implied, or assumes any legal liability or responsibility for the accuracy, completeness, or usefulness of any information, apparatus, product, or process disclosed, or represents that its use would not infringe privately owned rights. Reference herein to any specific commercial product, process, or service by trade name, trademark, manufacturer, or otherwise, does not necessarily constitute or imply its endorsement, recommendation, or favoring by the United States Government or any agency thereof. The views and opinions of authors expressed herein do not necessarily state or reflect those of the United States Government or any agency thereof. 


\section{DISCLAIMER}

This report was prepared as an account of work sponsored by an agency of the United States Government. Neither the United States Government nor any agency thereof, nor any of their employees, make any warranty, express or implied, or assumes any legal liability or responsibility for the accuracy, completeness, or usefulness of any information, apparatus, product, or process disclosed, or represents that its use would not infringe privately owned rights. Reference herein to any specific commercial product, process, or service by trade name, trademark, manufacturer, or otherwise does not necessarily constitute or imply its endorsement, recommendation, or favoring by the United States Government or any agency thereof. The views and opinions of authors expressed herein do not necessarily state or reflect those of the United States Government or any agency thereof. 


\section{DISCLAIMER}

Portions of this document may be illegible in electronic image products. Images are produced from the best available original document. 
Engineering Technology Division

\title{
LIGHTWEIGHT COMPOSITE FIGHTING COVER PROTOTYPE DEVELOPMENT PROGRAM
}

FINAL REPORT

\author{
G. E. Wrenn, Jr. \\ B. J. Frame \\ R. C. Gwaltney \\ M. A. Akerman
}

Date Published - July 1996

\author{
h \\ Oak Ridge National Laboratory
Oak Ridge, Tennessee 37831-8048 \\ Managed by \\ LOCKHEED MARTIN \\ ENERGY RESEARCH CORPORATION \\ for the \\ U.S. DEPARTMENT OF ENERGY \\ under contract DE-AC05-96OR22464
}


This page left blank intentionally 


\section{TABLE OF CONTENTS}

LIST OF FIGURES $\ldots \ldots \ldots \ldots \ldots \ldots \ldots \ldots \ldots \ldots \ldots \ldots \ldots \ldots \ldots$

ABSTRACT $\ldots \ldots \ldots \ldots \ldots \ldots \ldots \ldots \ldots \ldots \ldots \ldots \ldots \ldots \ldots \ldots \ldots \ldots \ldots \ldots \ldots$

1. INTRODUCTION $\ldots \ldots \ldots \ldots \ldots \ldots \ldots \ldots \ldots \ldots \ldots \ldots \ldots \ldots \ldots \ldots \ldots$

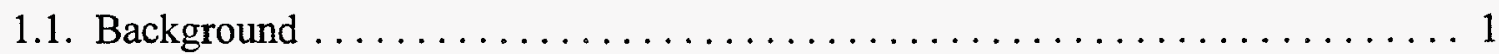

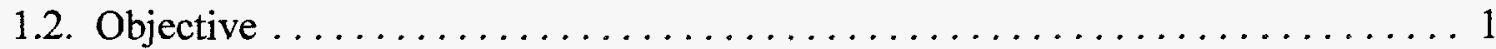

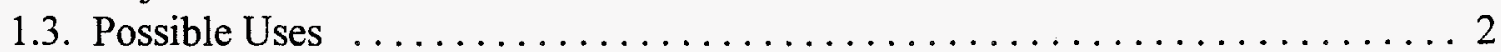

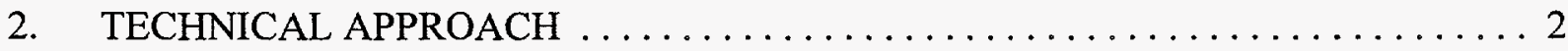

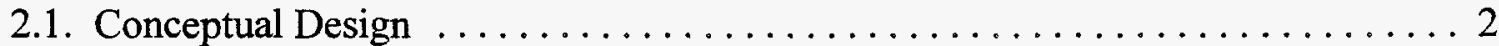

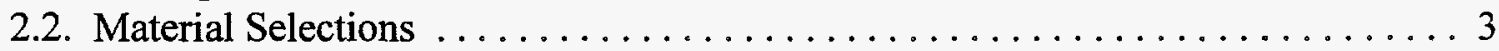

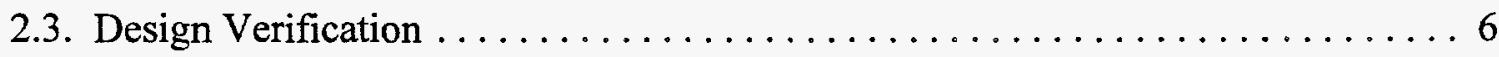

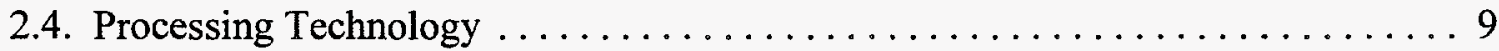

3. ENGINEERING PROTOTYPES $\ldots \ldots \ldots \ldots \ldots \ldots \ldots \ldots \ldots \ldots \ldots \ldots \ldots \ldots$

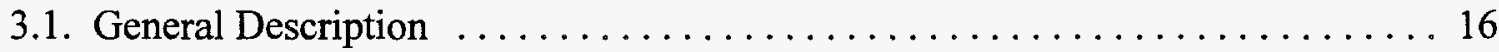

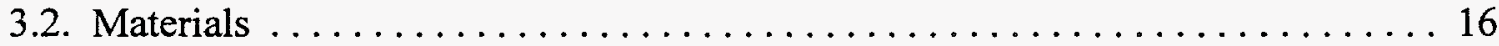

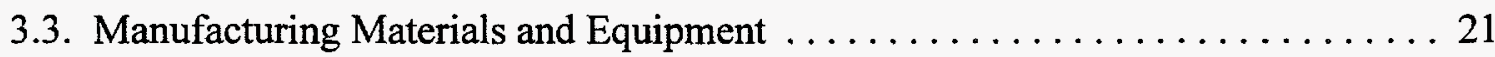

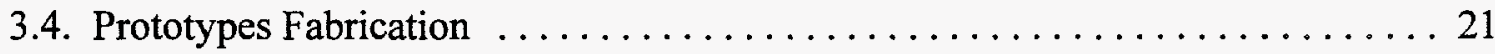

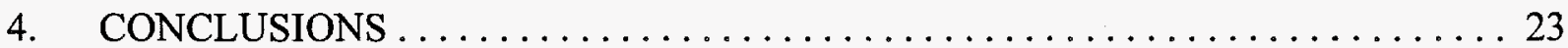

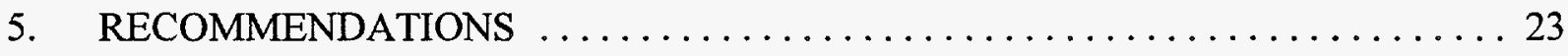

6. ACKNOWLEDGMENTS $\ldots \ldots \ldots \ldots \ldots \ldots \ldots \ldots \ldots \ldots \ldots \ldots \ldots \ldots \ldots \ldots$

Appendix A - Finite Element Analysis of Lightweight Composite Fighting Cover . . . . . A-1

Appendix B - Technical Data for Lightweight Composite Fighting Cover Materials ..... B-1 
This page left blank intentionally 


\section{LIST OF FIGURES}

Figure 1. Conceptual Design for Lightweight Composite Fighting Covers $\ldots \ldots \ldots \ldots \ldots 5$

Figure 2. Design Verification Bending Test Specimens $\ldots \ldots \ldots \ldots \ldots \ldots \ldots \ldots$

Figure 3. Design Verification Static Load Test Panel $\ldots \ldots \ldots \ldots \ldots \ldots \ldots \ldots$

Figure 4. Composite Panel Layup Materials $\ldots \ldots \ldots \ldots \ldots \ldots \ldots \ldots \ldots \ldots \ldots \ldots \ldots \ldots \ldots \ldots$

Figure 5. Composite Panel Stack Assembly $\ldots \ldots \ldots \ldots \ldots \ldots \ldots \ldots \ldots \ldots \ldots \ldots$

Figure 6. Composite Fighting Cover and Folding Cover Panel Section $\ldots \ldots \ldots \ldots 15$

Figure 7. Lightweight Composite Fighting Cover $\ldots \ldots \ldots \ldots \ldots \ldots \ldots \ldots \ldots$

Figure 8. Folding Lightweight Composite Fighting Cover $\ldots \ldots \ldots \ldots \ldots \ldots \ldots$

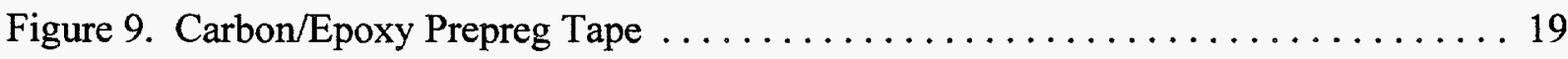


This page left blank intentionally 


\begin{abstract}
The U.S. Army Field Assistance Science and Technology Program requested Oak Ridge National Laboratory (ORNL) to demonstrate the use of lightweight composite materials in construction of overhead covers for reinforced infantry fighting positions. In recent years, ORNL researchers have designed and tested several concepts for lightweight ballistic protection structures, and they have developed numerous prototype composite structures for military and civilian applications. In the current program, composite panel designs and materials are tested and optimized to meet anticipated static and dynamic load conditions for the overhead cover structure. Ten prototype composite covers were built at ORNL for use in Army field tests. Each composite cover has a nominal surface area of $12 \mathrm{ft}^{2}$ and a nominal weight of $8 \mathrm{lb}$. Four of the prototypes are made with folding sections to improve their handling characteristics. The composite covers exhibit equivalent performance in Army field tests to covers made with conventional materials that weigh four times as much.
\end{abstract}




\section{INTRODUCTION}

\subsection{Background}

Oak Ridge National Laboratory (ORNL) recently developed several lightweight composite fighting cover concepts for the United States Army Field Assistance Science and Technology (FAST) Program. The ORNL concepts incorporate design elements for minimizing total weight of the fighting cover structure, while providing ballistic protection against grenade fragments and direct fire from small-caliber weapons. At the request of FAST, ORNL provided plans for development of a very lightweight fighting cover concept that would have high load-bearing and blast capability, but would offer little ballistic protection when used alone. This plan also provided the opportunity for demonstrating lightweight composite cover concepts, including the manufacture of up to ten prototype covers for the Army.

\subsection{Objective}

ORNL has undertaken the mission to develop and demonstrate composite cover concepts that minimize overall weight of the cover structure and offer high static and dynamic load-bearing capabilities. Prototype development and demonstration activities are performed under an interagency work agreement between the Army (Number 93-4D116) and the Department of Energy (Number 1644-C002-A1). The prototype composite covers utilize technologies and expertise developed previously by ORNL in other lightweight multilayer ballistic shielding programs and in composite materials fabrication programs sponsored by the Department of Defense, the Department of Energy, and other federal agencies.

ORNL proposed several options to enhance the structural performance of Army fighting covers:

(1) Build a honeycomb-core panel that has graphite/epoxy veneers and carrying straps bonded to outside surfaces. The composite panel provides little or no ballistic protection, but it is able to withstand high static and dynamic loads with minimum weight.

(2) Divide the structural panel into three sections that are connected with hinges. This enhancement allows the composite cover to be folded for easier transportation by infantry personnel, and offers additional ballistic protection while folded.

(3) Panels described in Option 1 and Option 2 may be slipped into a ballistic nylon envelope that contains additional ballistic protection layers made from polyethylene (Spectra) or aramid (Kevlar or Nomex) fiber materials.

At the direction of the Army, inherent ballistic protection features are not included in the ORNL prototype demonstration. The demonstration is limited to minimizing the weight of the basic fighting cover structure. ORNL is to provide ten prototype composite covers that are designed to withstand high static and dynamic loads, using the lightweight graphite/epoxy composite concept (Option 1). Hinged sections (Option 2) are to be included on four of the ten panels. 


\subsection{Possible Uses}

Composite covers are being considered for use in reinforcing infantry fighting positions. Dirt berms (or sandbags) are built up around the sides of a fighting position. The cover is placed over the fighting position, with two ends supported by the berms. Dirt (or sandbags) is piled on top of the cover to a depth of about two feet. The prepared position offers protection against shrapnel from near-miss artillery barrages, and is designed to withstand the a direct hit from a light mortar round without collapsing. Overall weight of the fighting cover should be no more than $35 \mathrm{lb}$.

The composite cover must suffer no degradation of its structural integrity from exposure to an outdoor environment. The most damaging conditions are caused by tropical environments, which expose the cover to heat and moisture for extended periods of time. In the past, the Army has used logs or plywood reinforced with wooden beams as fighting position covers. Tropical environments degrade the structural integrity of these wooden structures in only a few weeks. Furthermore the plywood covers, which must be used in areas without available timber, are not able to withstand a light mortar direct hit without collapsing.

The Army has conducted field tests to evaluate the performance of fighting covers in simulated battlefield conditions. Two parallel rows of sandbags are set up 24-30 in. apart. The fighting cover is placed on top of the sandbags, then covered over its entire surface with sandbags to a height of 24 in. The fighting cover is evaluated for a period of 30 days to determine if there is any deflection in addition to the initial deflection that occurred during loading. At the end of 30 days, ballistic tests are performed. An artillery barrage may be fired in the vicinity of the fighting position to produce near-miss shrapnel. Following the barrage, a charge containing $2 \mathrm{lb}$. of high explosive is set off on top of the sandbag-covered fighting cover to simulate a direct hit from a light mortar round. The direct force of this explosion is dampened by the 24-in. layer of sandbags, however a distributed dynamic load is still transmitted to the fighting cover. The cover is expected to deflect from the over pressure pulse and return to its normal position.

\section{TECHNICAL APPROACH}

\subsection{Conceptual Design}

ORNL has developed several ballistic protection concepts that are based on multiple-layer shields with significant internal spacing between selected layers. These designs offer inherent structural rigidity, as well as improved ballistic protection at reduced weight in comparison to either bulk materials or material laminates with no spacing. The ballistic protection features constitute the major source of weight in the ORNL shield concepts. Development of a composite cover that has no inherent ballistic protection allows ORNL researchers to focus on the lightweight structural characteristics of the multiple-layer spaced-shielding designs. 
Performance tests for composite covers, as conducted in Army field exercises, can be reduced to equivalent worst-case static and dynamic load requirements for the evaluation of materials options and structural design details. The static load requirement is represented by the weight per unit area of sandbags or wet soil placed on top of the cover.

\section{Static Load on Composite Panel}

Wet soil or sand $-110 \mathrm{lb} . / \mathrm{ft} .^{3}, 2 \mathrm{ft}$. depth

Total load on panel $\left(12 \mathrm{ft}^{2}\right)=2640 \mathrm{lb}$.

Unsupported load on panel $\left(7.5 \mathrm{ft}^{2}\right)=1650 \mathrm{lb}$.

Unit Area Static Load $=1.53 \mathrm{lb} . /$ in. $^{2}$

The dynamic load requirement is based on the over pressure pulse that is transmitted to the composite cover structure, through the 24-in. layer of soil from an explosive charge. The over pressure is related to the intensity of the blast and the distance from the explosion to the surface upon which the over pressure pulse is applied. The relationship is described by the following formula:

$$
\begin{aligned}
& \mathrm{P}^{3}=\mathrm{L}^{3} / \mathrm{W} \\
& \quad \text { in which } \\
& \mathrm{P} \text { is over pressure } \\
& \mathrm{L} \text { is distance from the blast } \\
& \mathrm{W} \text { is weight of explosive }
\end{aligned}
$$

The soil mass provides considerable attenuation of blast effects, as compared to a blast in air.

Dynamic Load on Composite Panel

Explosive Charge - $2 \mathrm{lb}$. C4, $2 \mathrm{ft}$. from cover

Over pressure (with attenuation through

24 in. of soil) $=25 \mathrm{lb} . / \mathrm{in}^{2}$

Duration of pulse $=2.5 \mathrm{~ms}$

\subsection{Materials Selection}

ORNL has been evaluating materials and lightweight structures for ballistic protection applications for nearly a decade. Ballistic shields incorporating a honeycomb core bonded to various materials as face sheets evolved as the best type of structure to resist over pressure loading from explosive detonations and projectile impingement from shrapnel or direct-fire weapons.

The lightweight composite cover is a sandwich structure that consists of face sheets bonded to a honeycomb core. Polymers incorporating several types of fiber reinforcement have been reviewed for use as face sheets in various ballistic protection fighting cover modifications. Performance characteristics of lightweight composite covers were evaluated using finite element analysis, presented in Appendix 1. The load bearing capability and over pressure resistance of the composite cover are maximized by increasing Young's modulus of the face sheets and increasing the Shear 
modulus of the core section. Carbon fiber reinforcement provides the highest Young's modulus in the face sheet materials. Optimizing the composite cover for minimum deflection and minimum weight drives the design to carbon fiber-reinforced face sheets, as shown in Figure 1.

Anticipated Static and Dynamic Load Deflections for

ORNL Lightweight Composite Fighting Cover - Preliminary Design

\section{Constants}

Bending Deflection

0.01302

Shear Deflection

0.125

Lambda $\left(1-\mathrm{M}^{2}\right)$

0.9

Face Sheet - Carbon/Epoxy Prepreg (65\% fiber fraction)

Three-Ply Laminate - 0 / 90 / 0

Young's Modulus (longitudinal)

$13.0 \mathrm{M} \mathrm{psi}$

Young's Modulus (transverse)

Core - Aluminum Honeycomb

Shear Modulus

$8.0 \mathrm{~K} \mathrm{psi}$

Dimensions

Facing Thickness (3 layers)

0.0156 in.

Section Thickness (core + facing)

0.5156 in.

Span

24 in.

Width

42 in.

Static Deflection

Total Load (1.6 psi)

$1575 \mathrm{lb}$.

Facing Deflection

0.1480 in.

Core Deflection

$0.0273 \mathrm{in}$.

Total Deflection

0.1753 in.

Dynamic Deflection

Total Load (26.6 psi)

$31815 \mathrm{lb}$. (treat as static load)

Facing Deflection

2.9887 in.

Core Deflection

0.5509 in.

Total Deflection

3.5396 in.

Comparing the anticipated static deflections of fighting covers made with various materials options shows the degree of structural rigidity and weight savings that are obtained using carbon fiber reinforcement in the face sheets. Aluminum honeycomb is used as the core material in all options. Cover size is $12 \mathrm{ft}^{2}{ }^{2}$. Cover weight includes edge sealing compound, a low-density epoxy that prevents deformation of open cells at the outside edge of the honeycomb. 
Folding Panel - Open

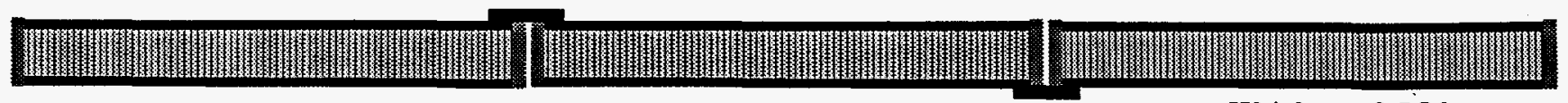

Weight $=8.5 \mathrm{Lb}$

Folding Panel - Closed

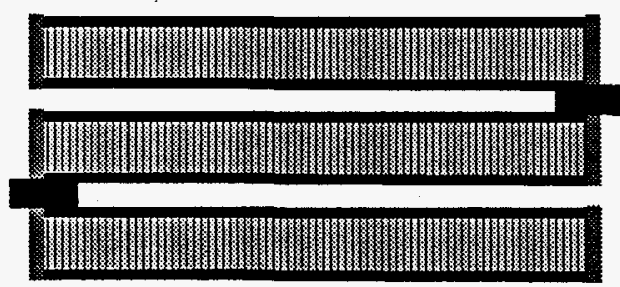

Materials of Construction

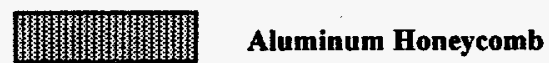

Three-Ply Carbon / Epoxy

Edge Sealing Compound

Rubberized Nylon Hinge

\section{Rigid Panel}

Weight $=7.5 \mathrm{Lb}$

Designed and built for the U.S. Army Forces Command, Fort McPherson, by the U.S. Department of Energy Oak Ridge National Laboratory Engineering Technology Division

Figure 1. Conceptual Design for Lightweight Composite Fighting Covers 


\begin{tabular}{|c|r|r|r|r|r|}
\hline $\begin{array}{c}\text { Face Sheet } \\
\text { Reinforcement }\end{array}$ & $\begin{array}{c}\text { Young's } \\
\text { Modulus }\end{array}$ & \multicolumn{1}{c|}{$\begin{array}{c}\text { Face } \\
\text { Thickness }\end{array}$} & $\begin{array}{c}\text { Core } \\
\text { Height }\end{array}$ & $\begin{array}{c}\text { Static Load } \\
\text { Deflection }\end{array}$ & \multicolumn{1}{c|}{$\begin{array}{c}\text { Cover } \\
\text { Weight }\end{array}$} \\
\hline $\begin{array}{c}\text { Glass } \\
\text { Fiber }\end{array}$ & $2 \mathrm{M} \mathrm{psi}$ & $0.063 \mathrm{in}$. & $1.5 \mathrm{in}$. & $0.59 \mathrm{in}$. & $13.2 \mathrm{lb}$. \\
\hline $\begin{array}{c}\text { Aluminum } \\
\text { Metal }\end{array}$ & $10 \mathrm{M}$ psi & $0.063 \mathrm{in}$. & $1.0 \mathrm{in}$. & $0.58 \mathrm{in}$. & $14.2 \mathrm{lb}$. \\
\hline $\begin{array}{c}\text { Aramid } \\
\text { Fiber }\end{array}$ & $19 \mathrm{M} \mathrm{psi}$ & $0.125 \mathrm{in}$. & $1.0 \mathrm{in}$. & $0.16 \mathrm{in}$. & $13.5 \mathrm{lb}$. \\
\hline $\begin{array}{c}\text { Polyethylene } \\
\text { Fiber }\end{array}$ & $24 \mathrm{M} \mathrm{psi}$ & $0.125 \mathrm{in}$. & $2.0 \mathrm{in}$. & $0.07 \mathrm{in}$. & $11.8 \mathrm{lb}$. \\
\hline $\begin{array}{c}\text { Carbon } \\
\text { Fiber }\end{array}$ & $33 \mathrm{M} \mathrm{psi}$ & $0.016 \mathrm{in}$. & $0.5 \mathrm{in}$. & $0.18 \mathrm{in}$. & $5.5 \mathrm{lb}$. \\
\hline
\end{tabular}

\subsection{Design Verification}

Three-point bending tests were performed on composite panel specimens made with carbon fiber and a core thickness of 0.5 in. Specimens with surface dimensions of 10 -in. by 1 -in. were cut from 12-in. by 4-in. test panels. Each specimen was supported on two 1-in. diameter cylinders spaced 9.2in. apart. Load was applied through a 1 -in. diameter cylinder at mid-span using a hydraulic press. Deflection and load were monitored, along with strain on the tensile surface of the specimen.

Three specimens were of carbon fiber/ 0.5 in. core tested until failure. Failure was determined by evaluating the peak load sustained by each specimen. Failure mode was determined by examining the specimen after testing. The initial specimen suffered local deformation on the compression surface, directly under the mid-span cylinder. A 2-in. long spreader plate was used in the remaining tests.

Bending Test Results

Specimen

Peak Force (lb.)

Bending Moment (lb. in.)

Equiv. Uniform Load (psi)

Deflection (in.)

Deflection (calc.)

Failure Mode

(observed)
A

80

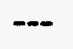

$---$

0.065

0.060

Face

Wrinkle
B

128

230.4

21.7

0.100

0.110

Core

Buckle
C

120

216.0

20.4

0.100

0.090

Core

Buckle 
Quasi-isostatic uniform loads of 20-21 psi were predicted for specimens using equivalent bending moment at mid-span as the basis for calculations. It is interesting to note that both specimens tested with the spreader plate failed by buckling of one or more cell walls at a beam deflection of $0.100 \mathrm{in}$. The adhesive film used to join face layers to the core produced strong bonds that exceeded the shear strength of the core material. Damage to the three specimens is shown in Figure 2.

Based on these results, core thickness for the prototype lightweight composite cover was increased from $0.5 \mathrm{in}$. to $1.0 \mathrm{in}$. to increase the bending stiffness of the composite panel structure. Cell size and wall thickness of the honeycomb were modified to maintain equivalent weight for the core structure. The added section stiffness obtained by increasing the height of the core more than compensated for decreases in the specific stiffness of the materials and ensures that the composite structure will not deflect sufficiently under design loads to initiate failure by buckling of cell walls.

Anticipated Static and Dynamic Load Deflections for ORNL Lightweight Composite Fighting Cover - Final Design

\section{Constants}

Bending Deflection

0.01302

Shear Deflection

0.125

Lambda $\left(1-\mathrm{M}^{2}\right)$

0.9

Face Sheet - Carbon/Epoxy Prepreg (65\% fiber fraction)

Three-Ply Laminate

Young's Modulus (longitudinal)

Young's Modulus (transverse)

$0^{\circ} / 90^{\circ} / 0^{\circ}$

$13.0 \mathrm{M}$ psi

7.0M psi

Core - Aluminum Honeycomb

Shear Modulus (span)

45.0K psi

Shear Modulus (cross)

$1.5 \mathrm{~K}$ psi

Dimensions

Facing Thickness (3 layers)

Section Thickness (core + facing)

Span

Width

0.0156 in.

$1.0156 \mathrm{in}$.

$24 \mathrm{in.}$

36 in.

Static Deflection

Total Load (1.6 psi)

$1320 \mathrm{lb}$.

Facing Deflection

0.1066 in.

Core Deflection

0.0712 in.

Total Deflection

0.1778 in. 


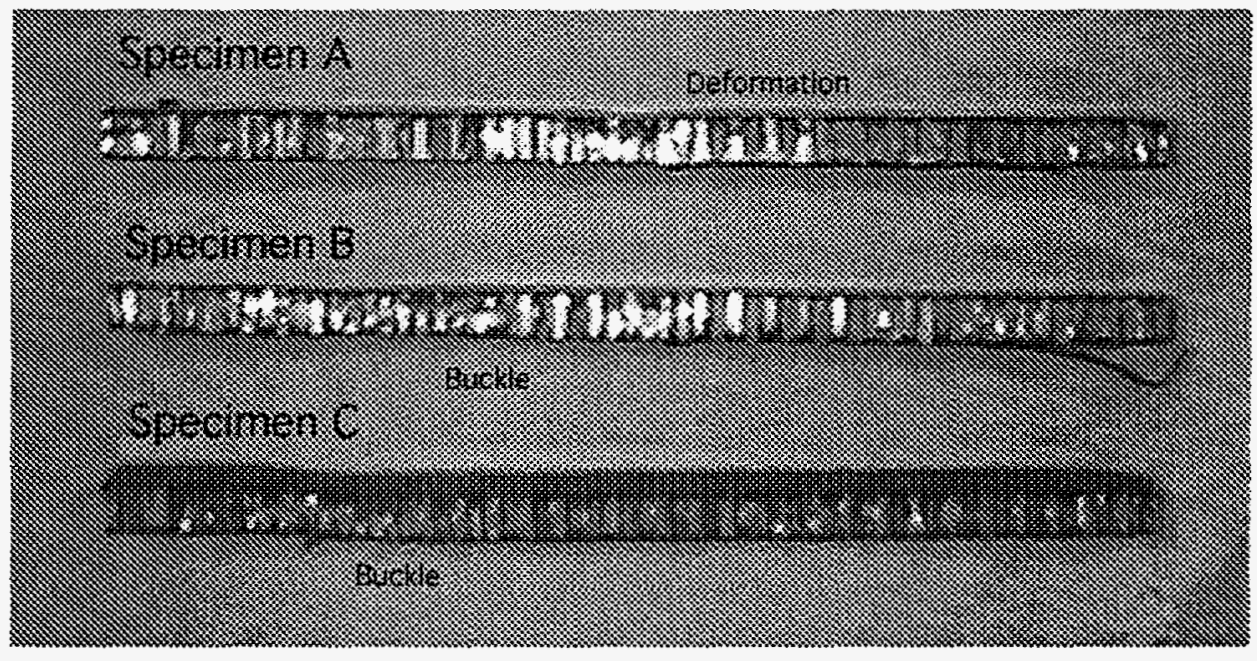

Figure 2. Design Verification Bending Test Specimens 
Anticipated Static and Dynamic Load Deflections for

ORNL Lightweight Composite Fighting Cover - Final Design Continued

Dynamic Deflection

Total Load (26.6 psi)

$22920 \mathrm{lb}$. (treat as static load)

Facing Deflection

$1.4791 \mathrm{in}$.

Core Deflection

$0.0824 \mathrm{in}$.

Total Deflection

$1.5615 \mathrm{in}$

\begin{tabular}{|c|r|r|r|r|r|}
\hline $\begin{array}{c}\text { Face Sheet } \\
\text { Reinforcement }\end{array}$ & $\begin{array}{c}\text { Young's } \\
\text { Modulus }\end{array}$ & $\begin{array}{c}\text { Face } \\
\text { Thickness }\end{array}$ & $\begin{array}{c}\text { Core } \\
\text { Height }\end{array}$ & $\begin{array}{c}\text { Static Load } \\
\text { Deflection }\end{array}$ & $\begin{array}{c}\text { Cover } \\
\text { Weight }\end{array}$ \\
\hline $\begin{array}{c}\text { Carbon } \\
\text { Fiber }\end{array}$ & $33 \mathrm{M} \mathrm{psi}$ & 0.016 in. & $1.0 \mathrm{in}$. & $0.18 \mathrm{in}$. & $7.5 \mathrm{lb}$. \\
\hline
\end{tabular}

A somewhat less rigorous static load test was performed to confirm the predicted behavior of composite panel prototypes. A distributed load of $550 \mathrm{lb}$ was placed on a $12 \mathrm{in}$. by $48 \mathrm{in}$. by 1 in. section of a lightweight folding composite cover, as shown in Figure 3. Beam deflection of 0.5 in. was observed at the midpoint of a 40-in. test span. The test panel is subjected to significantly higher compressive loading at the span supports, since the narrow edge of a $2 \times 6$ lumber beam provides only 18 in. $^{2}$ of loading area at each support, versus an area of $72-144$ in. $^{2}$ for sandbags.

\subsection{Processing Technology}

Lightweight composite fighting covers are made in a six-step manufacturing process, including hinge attachment for folding covers. Face layers of three-ply carbon/epoxy are bonded to a core of aluminum honeycomb to form the basic composite cover structure. After resins in the structure have been cured, edges are trimmed to remove damaged or deformed honeycomb cells. The edges are then sealed with a low-density epoxy compound that fills in open cells to prevent their collapse in use. Individual panels in folding composite covers are then joined together with neoprene-coated nylon fabric hinges. The hinges are attached with an epoxy resin.

Step 1 - Prepreg Layup and Debulking

Carbon/epoxy composite face layers are made by laying up three plies of uniaxial prepreg tape. Ply orientations are $0^{\circ} / 90^{\circ} / 0^{\circ}$, using the long dimension of the panel as the reference axis. Excess air trapped between the plies is removed by applying a vacuum for $30 \mathrm{~min}$. 


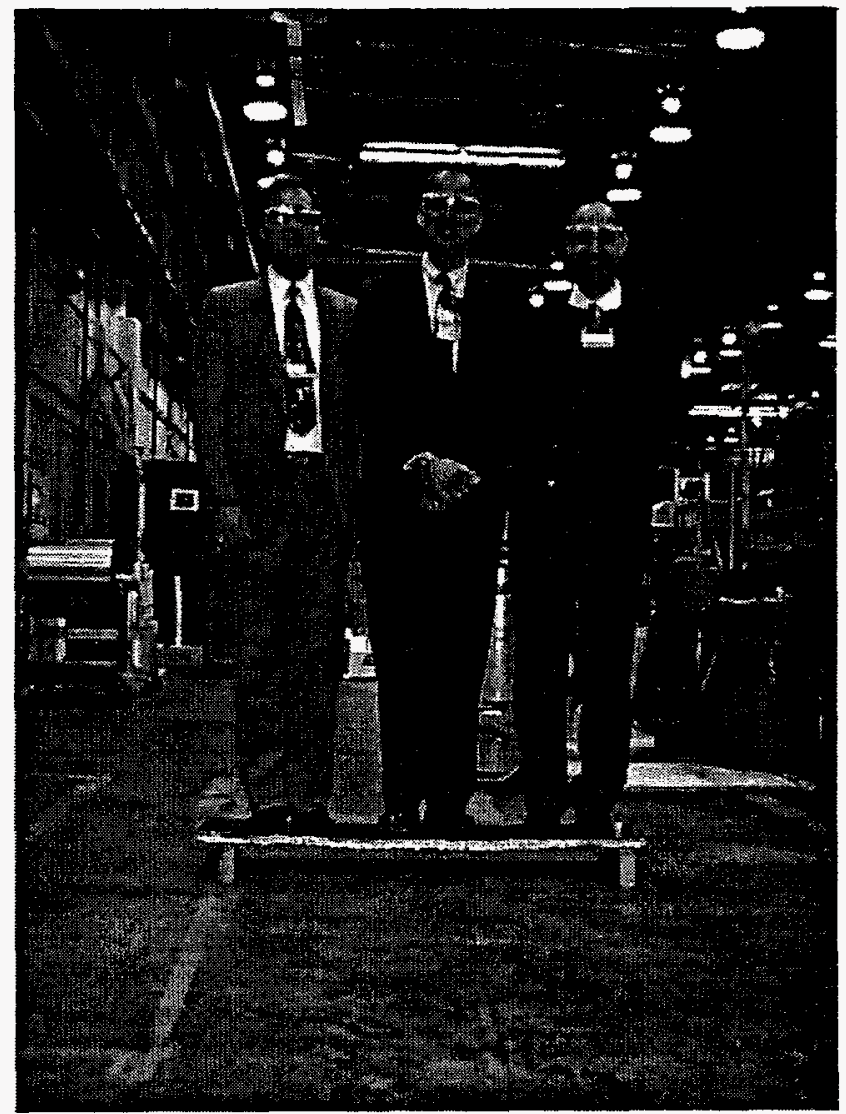

Figure 3. Design Verification Static Load Test Panel 


\section{Step 2 - Composite Structure Stack Assembly}

Composite cover materials are assembled to form a flat panel structure that can be co-cured in one heat treatment. Folding panel section components are shown in Figure 4, along with a base plate and a completed panel. One three-ply facing layer is in the foreground, followed by a sheet of adhesive film that is placed atop the honeycomb core. Aluminum is used as a mold (base plate) for the panel structure. The entire stack assembly is shown schematically in Figure 5. It is built up as follows:
(1) base plate;
(2) release film;
(3) three-ply carbon/epoxy;
(4) adhesive film;
(5) honeycomb panel;
(6) adhesive film;
(7) three-ply carbon/epoxy;
(8) release film;
(9) caul plate;
(10) edge support frame;
(11) cheese cloth breather layer; and
(12) vacuum bag.

Note - It is of critical importance to the structural integrity of the composite cover that honeycomb cells are oriented with longitudinal direction (points) parallel to long dimension of the panel.

Note - The caul plate is required to prevent dimpling and wrinkling of the upper three-ply layer of carbon/epoxy. Air pressure resulting from the application of vacuum during the cure cycle is sufficient to deform the composite material unless it is protected with a caul plate. The plate must be flexible enough to conform to the contours of the base plate or mold.

Note - The edge support frame is required to prevent air pressure from acting on the sidewalls of the honeycomb layer during curing. Without edge support, air pressure deforms the honeycomb cells in the transverse direction. Use of the caul plate, alone, cannot prevent this deformation from occurring. The frame is made from aluminum angle stock 1.25 in. by 1.25 in. by 0.063 in. web. Frame dimensions (length, width, and height) need to be slightly larger than dimensions of the assembled panel components, but not extend below the bottom edge of the base plate. 


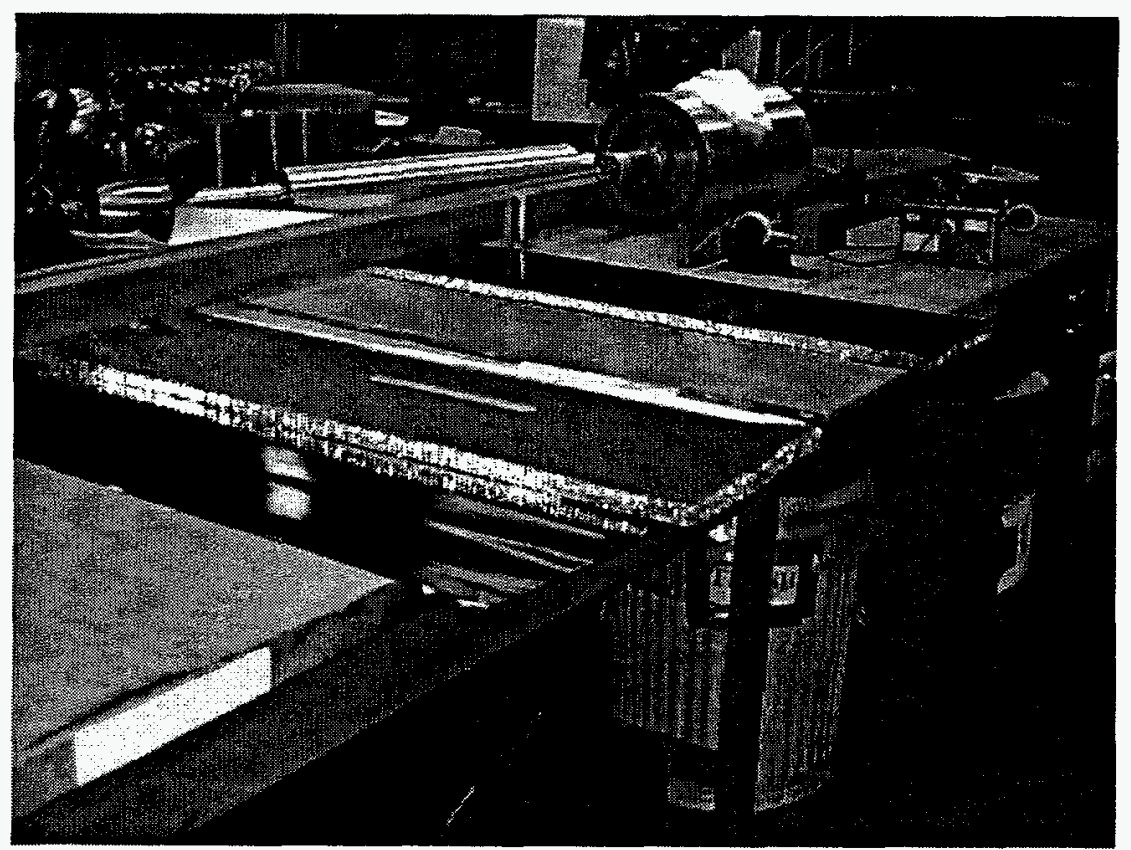

Figure 4. Composite Panel Layup Materials 


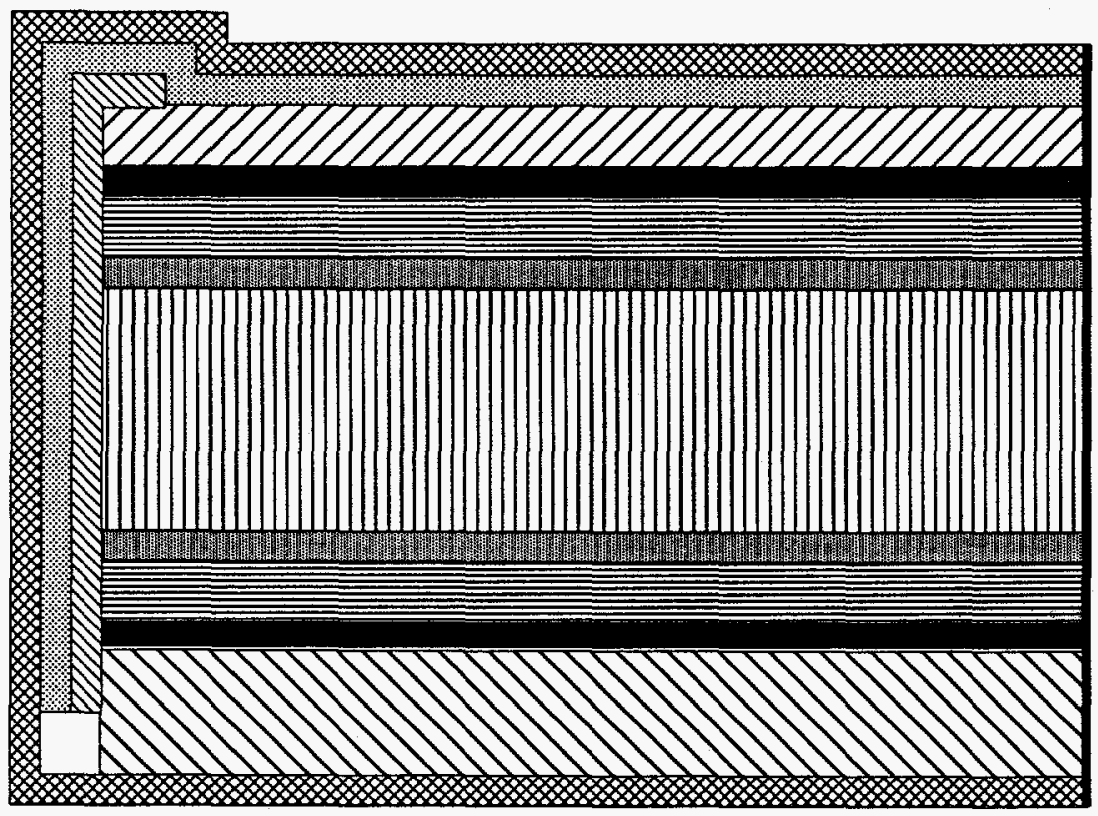

Vacuum Bag

Breather Cloth

Edge Protector

PA caul Plate

|IIII] Honeycomb

Adhesive Film

Carbon/Epoxy

Release Film

DV Base Plate

Figure 5. Composite Panel Stack Assembly 
Step 3 - Vacuum-Assisted Oven Cure

The entire stack assembly, including the mold, is enclosed in a vacuum bag and placed in curing oven that is preheated to $100^{\circ} \mathrm{F}$. Oven temperature is raised from $100^{\circ} \mathrm{F}$ to $250^{\circ} \mathrm{F}$ over a period of 25-35 min., then maintained at temperature for $120 \mathrm{~min}$. Resins in the face layers and adhesive film layers bond the carbon fiber plies to each other and to the honeycomb, assisted by a combination of heat and air pressure. Vacuum is maintained throughout the cure cycle, including cool down from $250^{\circ} \mathrm{F}$ to $100^{\circ} \mathrm{F}$.

\section{Step 4 - Excess Stock Removal}

Honeycomb materials are supplied in oversize sheets to allow removal of damaged or deformed edge cells following attachment to face layers. Composite panels are made with sufficient excess stock on each edge to ensure that all material in the usable portion of the panel contains face sheets bonded to correctly shaped core cells. Trimmed panels for a lightweight composite cover and one section of a folding cover are shown in Figure 6.

Machining experiments were performed to determine optimum cutting speed and feed rates for composite panels made with cores of 1 -in. honeycomb. Cuts are made on a horizontal mill using a 6-in. diameter diamond wheel that is run at $500-600 \mathrm{rpm}$. The travel table on mill must have a working length of at least 54 in. Longitudinal cuts on the composite panel can be made at a feed rate of 1.0-1.5 in/min. Transverse cuts can be made at a feed rate of 0.7-1.0 in./min. Panels are marked near one longitudinal edge before cutting to ensure proper alignment with the composite structure.

Note - Milling bits or toothed saws cannot be used to cut the composite panels. These tools cause unacceptable damage to the carbon/epoxy face layers.

Step 5 - Composite Panel Edge Sealing

Open cells on edges of cut panels are filled in using a low-density potting compound that is designed for use with honeycomb panel structures. The resin has a lower density and a higher compressive strength than most epoxies. Resin is packed into open cells along the edges of each panel using a spatula. The surface of the resin is warmed using a heat gun to reduce its viscosity, then it is smoothed with the spatula. Panels are placed in curing oven that is preheated to $100^{\circ} \mathrm{F}$. Oven temperature is raised from $100^{\circ} \mathrm{F}$ to $250^{\circ} \mathrm{F}$ over a period of $25-35$ min., then maintained at temperature for $120 \mathrm{~min}$. to cure the resin.

Step 6 - Hinge Attachment

Hinges for folding composite cover panels are made from neoprene-coated nylon fabric. The nylon is cut into strips 48 -in. long by 4.5 -in. wide. The rubber surface is cleaned in preparation for bonding by wiping it with a cloth soaked in toluene. A 2-in. wide strip at the edge of a composite panel is prepared by lightly abrading the surface with fine-grained sandpaper. Area adjacent to the strip is masked to prevent abrasion and catch excess adhesive. 


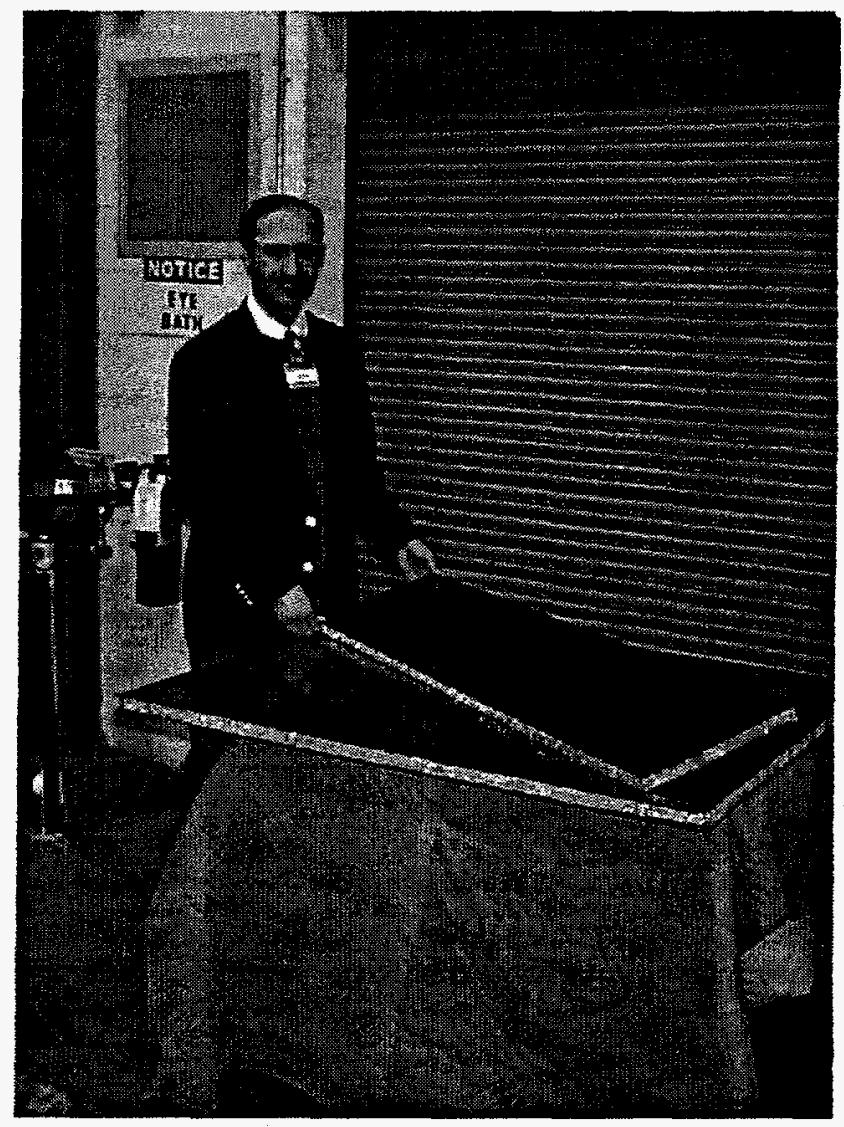

Figure 6. Composite Fighting Cover and Folding Cover Panel Section 
When the surfaces of two panels and one hinge have been prepared, an epoxy paste is spread over the bonding areas of both panels and the hinge. The panels are positioned next to each other, and the hinge is placed on top of both panels. Release film, a strip of sheet metal, and weights are then placed on top of the hinge to help set the adhesive and force excess resin out of the bond area. Masking is removed after one hour. The resin system fully cures at room temperature over a period of seven days, however the panels can be handled after 16-20 hr. Weights are removed at that time, and the panels are placed in a curing oven set at $120^{\circ} \mathrm{F}$ for $2 \mathrm{hr}$. to accelerate the curing cycle for the adhesive.

Note - Nylon fabric with no coating was also tested for use as a hinge. The bonding adhesive soaked into the fabric, causing an unacceptable reduction in its flexibility. Qualitative peel tests were performed on coated and uncoated nylon fabric samples that were bonded to a carbon/epoxy composite surface. Peel characteristics and apparent bond strength were similar for the two hinge materials.

\section{ENGINEERING PROTOTYPES}

\subsection{General Description}

Ten lightweight composite fighting cover prototypes were built by ORNL for the U. S. Army. Surface dimensions of the baseline Army fighting cover are 51 in. by 42 in. The ORNL fighting cover prototypes are built with surface dimensions of $48 \mathrm{in}$. by $36 \mathrm{in}$. The slightly smaller size helps conserve materials and reduce costs for demonstration of the ORNL design concepts without degrading performance of the prototype in field tests.

Two kinds of lightweight composite fighting covers are prototyped, as shown in Figure 7 and Figure 8. The first kind is a single panel with dimensions of 36 in. by 46 in. by 1 in. Six of these panels were built for the Army. The second kind is a folding panel consisting of three sections that are connected with coated fabric hinges. Each section has dimensions of $12 \mathrm{in}$. by 48 in. by 1 in. Four of these panels were built for the Army.

The following discussions provide information on the materials, processes, and types of equipment used to build the lightweight composite fighting cover prototypes.

\subsection{Materials}

(1) Carbon Fiber Prepreg. The carbon/epoxy face sheets are potentially the costliest material in the composite panel. Commercial grade carbon fiber provides adequate strength and stiffness in the face layer, even in the minimum configuration of three-ply construction. Aerospace grades of carbon fiber offer $30-50 \%$ higher strength and stiffness, however the cost of these materials is 300-500\% higher. Cut segments of prepreg tape are shown in Figure 9, along with a spool of carbon fiber tow for comparison. Fiber content of the prepreg is $5.3 \mathrm{oz} . / \mathrm{ft}^{2}$. Resin content is 35 wt.\% Type 8804 epoxy. 


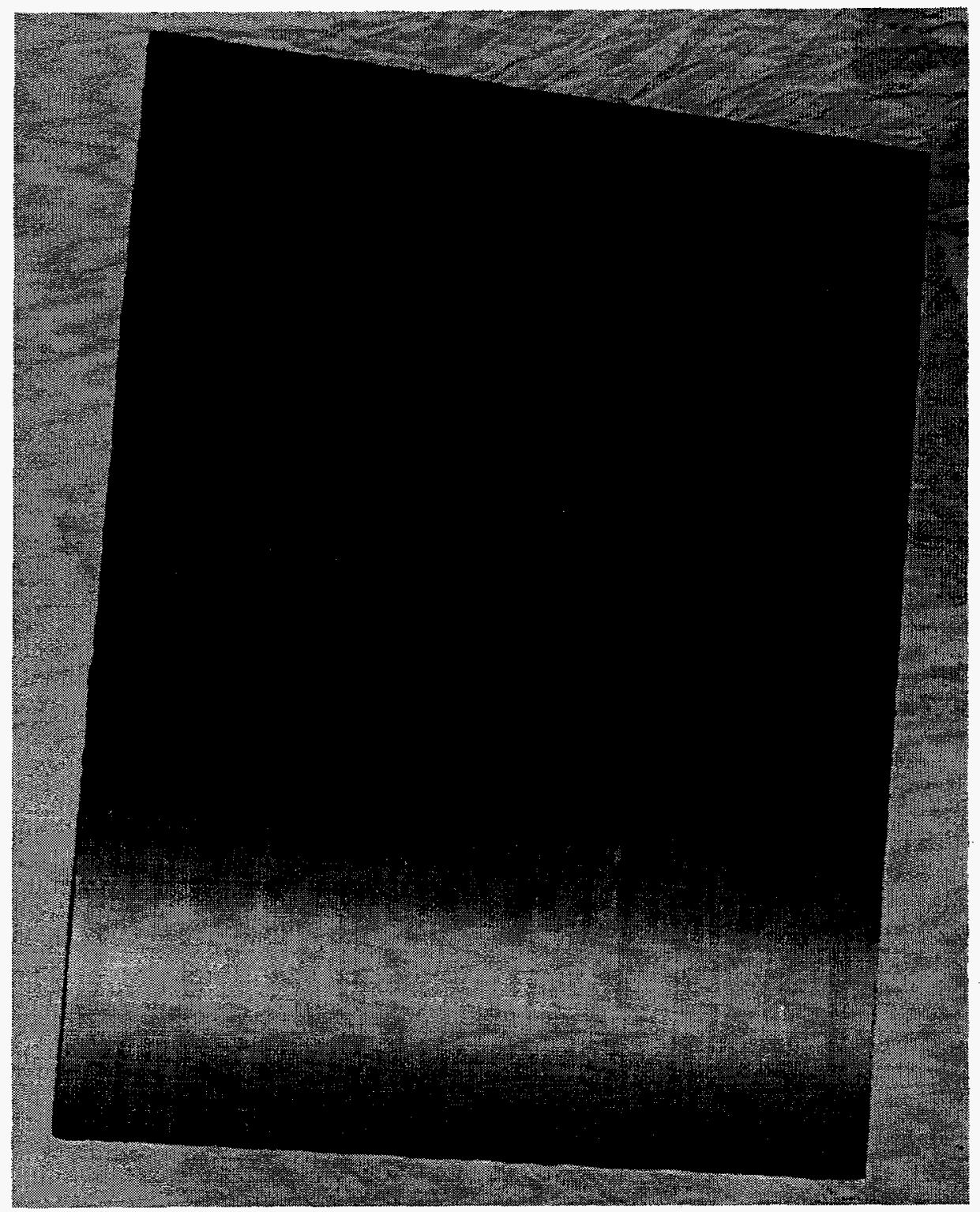

Figure 7. Lightweight Composite Fighting Cover 


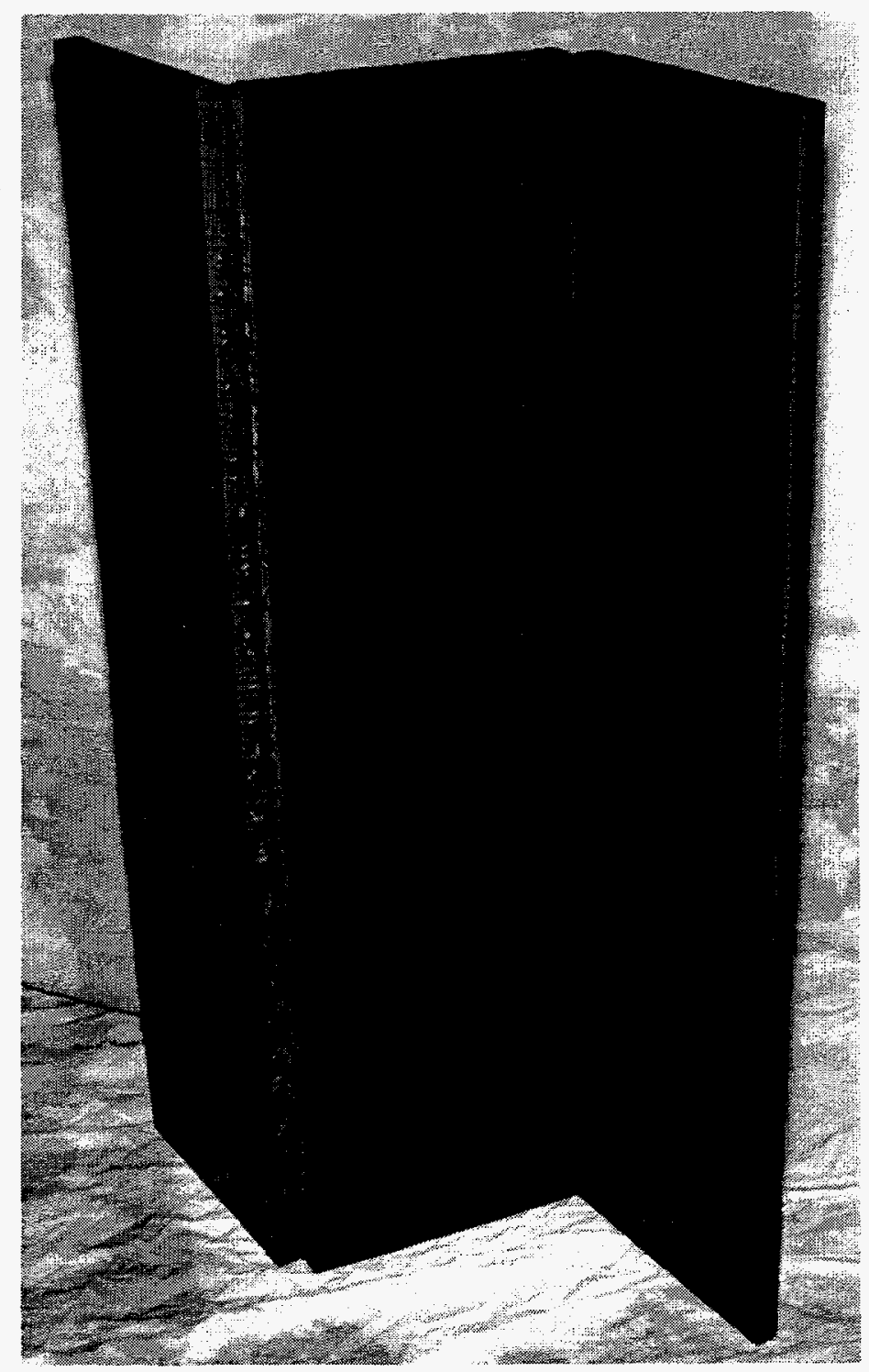

Figure 8. Folding Lightweight Composite Fighting Cover 


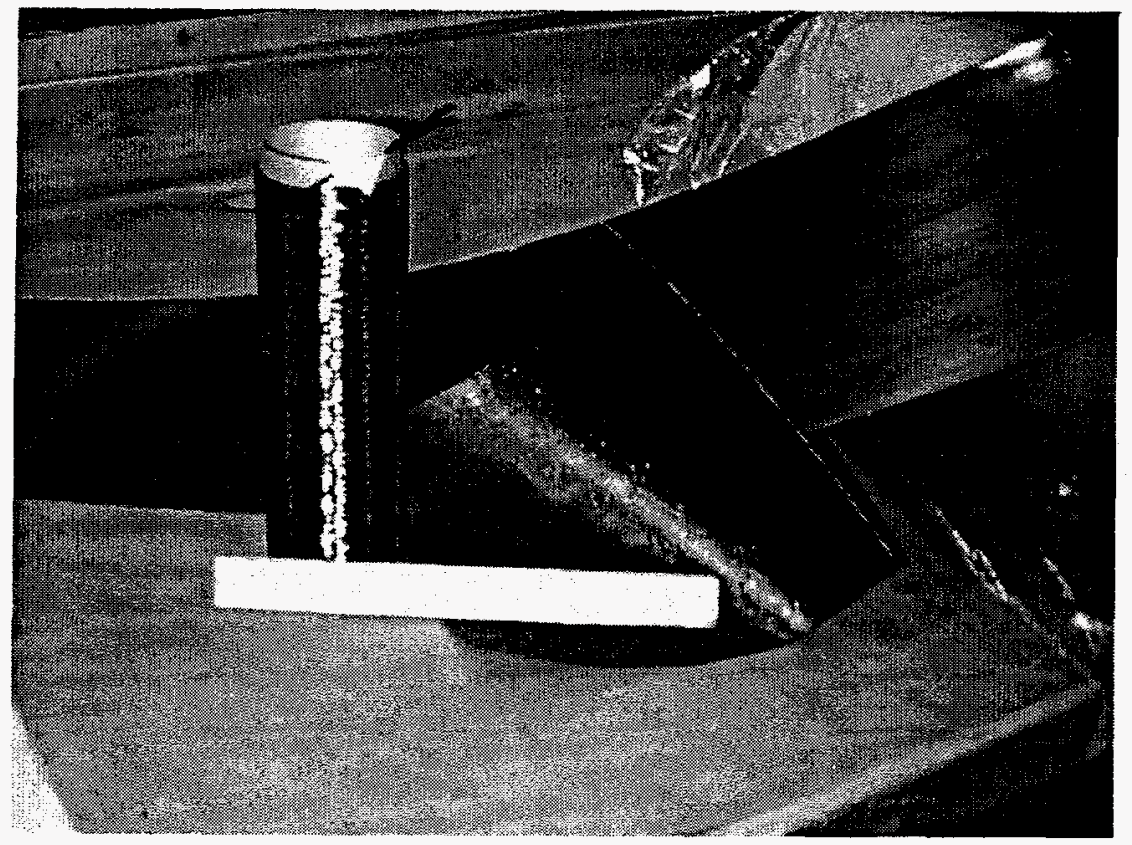

Figure 9. Carbon/Epoxy Prepreg Tape 
(2) Aluminum Honeycomb. Honeycomb structures are available in various polymers, fiberreinforced polymers, and metals. Aluminum provides the most shear strength per unit weight, and it suffers the least environmental degradation. Pre-cut honeycomb sheets are used in the prototypes to facilitate handling in laboratory settings. They still required post-fabrication trimming to obtain final panel dimensions. The honeycomb material used in prototypes is made using aluminum alloy 5052. Cell size is $0.188 \mathrm{in}$. (wall to wall). Foil gauge is $0.0007 \mathrm{in}$. There are no perforations in the foil, as this would seriously degrade its resistance to buckling.

(3) Structural Adhesive Film. Epoxy film adhesive is used to bond face sheets to the honeycomb core. The adhesive must have similar curing characteristics as the resin used in the prepreg material. Several film thicknesses are available. Nominal film thickness of 0.010 in. is used to ensure development of an adequate bonding web between the face sheets and the core.

(4) Edge Sealing Compound. The epoxy compound used to seal exposed edges of the composite panel also serves a structural function. Incomplete honeycomb cells at the edges of a panel are more susceptible to buckling or crushing. The cured resin has sufficient compressive strength to support the panel structure at this location.

(5) Neoprene-Coated Nylon Fabric. Commercial material is used in this application.

(6) Adhesive Paste. This epoxy adhesive is used to develop bonds that will resist the most of the stresses that might cause hinges to peel from panels.

The approximate amounts and small-quantity procurement costs of materials used in each type of composite cover are shown in the following tables. Costs are typical for each type of material used, without regard to the manufacturer. Additional manufacturer technical information about specific materials is provided in Appendix 2.

\section{Materials Used in ORNL Lightweight Composite Fighting Cover}

Size: 36 in. by 46 in. by 1 in.

Component

Carbon Fiber Prepreg

Aluminum Honeycomb

Structural Adhesive Film

Edge Sealing Compound
Commercial Material

Fortafil 3(C)/8804

Plascore 5052

Scotch-Weld AF163-2M

Cyanamid BR-624
Amount per Cover

Weight Cost

$3.66 \mathrm{lb} . \quad \$ 85$

$1.90 \mathrm{lb} . \quad \$ 122$

$1.37 \mathrm{lb} . \quad \$ 65$

$0.46 \mathrm{lb} . \quad \$ 13$

Total $\quad 7.39 \mathrm{lb} . \quad \$ 285$ 
Size: 36 in. by 48 in. by 1 in. (open)

12 in. by 48 in. by 3 in. (closed)

\begin{tabular}{|c|c|c|c|}
\hline \multirow[b]{2}{*}{ Component } & \multirow[b]{2}{*}{ Commercial Material } & \multicolumn{2}{|c|}{ Amount per Cover } \\
\hline & & Weight & Cost \\
\hline Carbon Fiber Prepreg & Fortafil 3(C)/8804 & $3.85 \mathrm{lb}$. & $\$ 89$ \\
\hline Aluminum Honeycomb & Plascore 5052 & $2.00 \mathrm{lb}$. & $\$ 100$ \\
\hline Structural Adhesive Film & Scotch-Weld AF163-2M & $1.44 \mathrm{lb}$. & $\$ 68$ \\
\hline Edge Sealing Compound & Cyanamid BR-624 & $0.76 \mathrm{lb}$ & $\$ 20$ \\
\hline Neoprene-Coated & & & \\
\hline Nylon Fabric & no specification & $0.30 \mathrm{lb}$ & \\
\hline Structural Adhesive Paste & Hysol EA-9330 & $0.08 \mathrm{lb}$ & \\
\hline & Total & $8.43 \mathrm{lb}$. & $\$ 2$ \\
\hline
\end{tabular}

\subsection{Manufacturing Materials and Equipment}

Base Plate Aluminum plate stock (for ease in handling), nominal 0.5 in. thick.

Caul Plate Any suitable metal sheet stock, nominal 0.063 in. gauge.

Edge Support Any suitable metal angle stock, with web lengths of 1.125 in. to 1.1375 in.

Any suitable commercial products can be used for the following manufacturing items, based on the preferences of the fabricator and the availability of resources:

$\begin{array}{lll}\text { Release Film } & \text { Cheese Cloth } & \text { Vacuum Bag Bag Sealer } \\ \text { Vacuum Pump } & \text { Curing Oven } & \text { Horizontal Mill or Water-Jet Cutter }\end{array}$

\subsection{Prototypes Fabrication}

Ten prototype lightweight covers were built using composite manufacturing steps described in the Technical Approach. The six lightweight composite covers each required about eight hours of effort to build and finish. The four folding lightweight composite covers each required about 12 hours of effort to build, finish, and assemble. Approximately $50 \%$ of the total effort expended for each version of the composite cover was expended in trimming excess stock from honeycomb sheets and from cured panels. 


\section{ORNL Lightweight Composite Fighting Cover}

Size: 36 in. by 46 in. by 1 in.

$\begin{array}{clc}\begin{array}{c}\text { Process } \\ \text { Step }\end{array} & \text { Description } & \begin{array}{c}\text { Time } \\ (\mathrm{Hr})\end{array} \\ 1 & \text { Prepreg Layup and Debulking } & 1 \\ 2 & \text { Composite Panel Stack Assembly } & 1 \\ 3 & \text { Vacuum-Assisted Oven Cure } & 1 \\ 4 & \text { Excess Stock Removal } & 4 \\ 5 & \text { Composite Panel Edge Sealing } & 1 \\ & \text { Total } & 8 \\ & & \\ & \text { ORNL Folding Lightweight Composite Fighting Cover }\end{array}$

Size: 36 in. by 48 in. by 1 in. (open)

12 in. by 48 in. by 3 in. (closed)

Process

Step

Description

Time

5

Prepreg Layup and Debulking

Composite Panel Stack Assembly

Vacuum-Assisted Oven Cure

(Hr)

1

2

3

4

5

Excess Stock Removal

Composite Panel Edge Sealing

Hinge Attachment

1
1
1
6
2
1

Total

Fabrication costs of the ten first-of-a-kind prototypes are in the range of $\$ 1000-2000 /$ unit. This cost can be reduced by several routes: (1) The cost basic materials in small-quantity orders is high. In some cases, the minimum order quantity is several times the amount actually needed. Material costs for high-volume production quantities should be $25-30 \%$ less. (2) Existing processes and equipment were adapted to produce prototypes. Labor and materials can be used more efficiently by tailoring manufacturing processes to build the cover structures. For example, the ability to use trimmed versus untrimmed honeycomb material would lower unit cost for this component from $\geq \$ 100$ per cover to $\leq \$ 10$. (3) Final trimming of panel edges is a labor-intensive step. Use of a water-jet cutter would be somewhat faster. Additional testing is also needed to determine if the static and dynamic loads on the cover require perfect cell structure up to the edge or if there is an acceptable zone of imperfect cells near the edge that would allow fabrication with no final edge trimming. 


\section{CONCLUSIONS}

Lightweight fighting covers were designed and built from composite materials. Weighing only eight pounds, the composite covers have structural characteristics that should meet Army needs for static and dynamic loading-bearing capability under battlefield conditions. Design and analysis philosophies for multiple-layer lightweight ballistic shielding concepts are valid for development and evaluation of soldier fighting cover mechanical properties and failure modes.

\section{RECOMMENDATIONS}

Future demonstrations of lightweight composite fighting cover technology should examine methods for minimizing manufacturing costs while maintaining the functional quality of the cover. In addition, research is needed to modify the design of cover structures to maximize their utility in the construction of both in-ground and above-ground protective structures and to evaluate the costs and benefits of enhancing ballistic protection capabilities within the cover structure.

\section{ACKNOWLEDGMENTS}

The authors wish to recognize the important contributions made by the following researchers in the development and prototyping of lightweight soldier fighting covers:

D. Skidmore and R. D. Lomax for developing and demonstrating processing technologies for lightweight covers and serving as lead technologists for building prototypes;

R. L. Battiste and T. D. Godwin for instrumenting composite specimens and performing flexure tests; and

C. L. Knaff and R. W. Starr for support in building prototype covers for the Army. 
APPENDIX A. FINITE ELEMENT ANALYSIS OF LIGHTWEIGHT SOLDIER FIGHTING COVER 


\section{Fighting Cover}
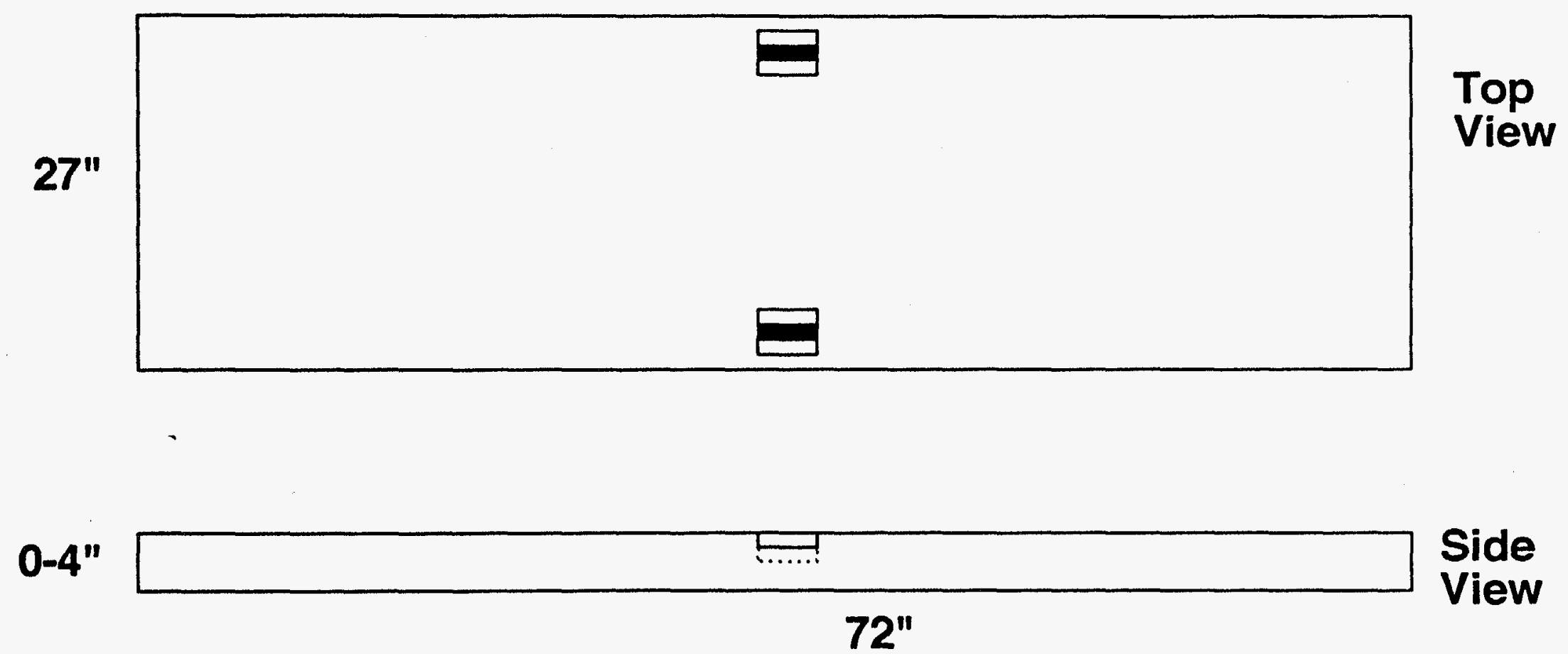

This design was selected for further evaluation. Parts of this design are the subject of a patent application filed with US Patent Office Nov. 12, 1992. 

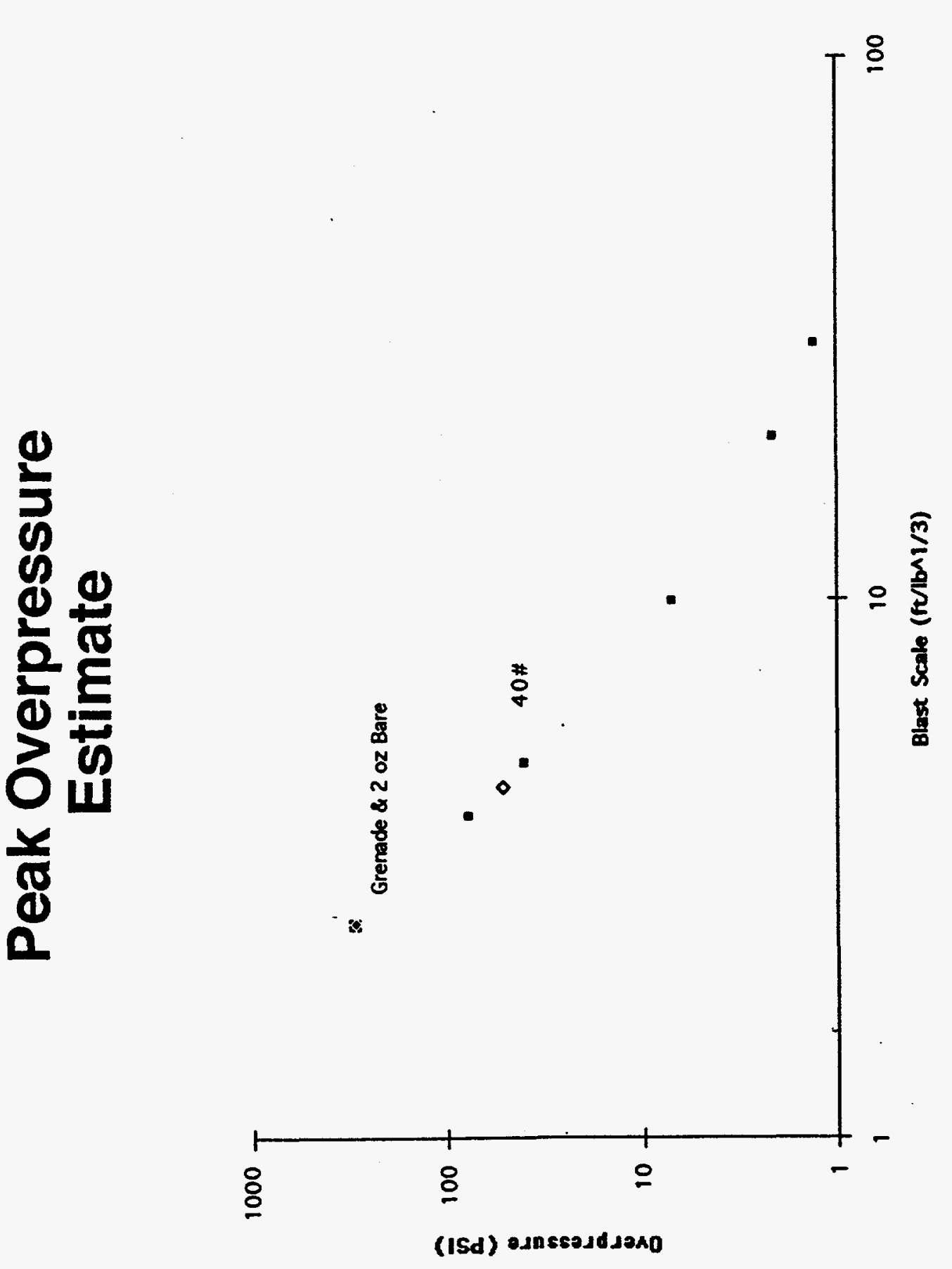

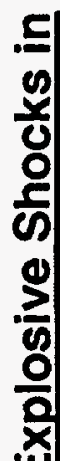

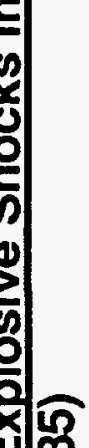

யळ

Eᄐ ㅇํㅇ ชั

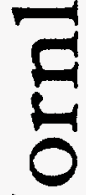
잉

통 क 둥 웅 ;든 웡 憅

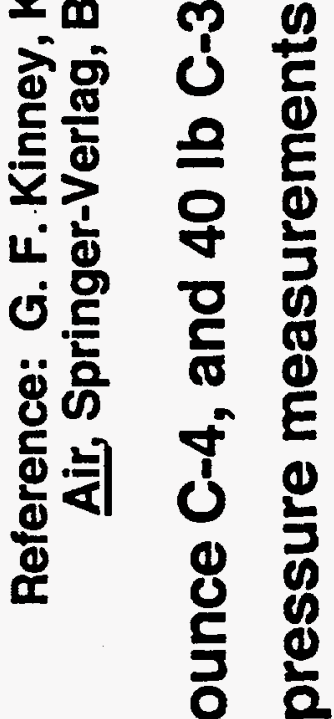
人 2 产 $\frac{0}{0} \frac{1}{0}$

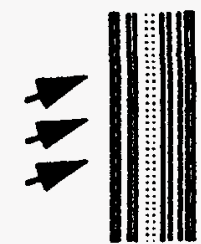




\section{Material Data and Calculations Fighting Cover - 3 Layer Model}

G10 Fiberglass/Aluminum Honeycomb Construction

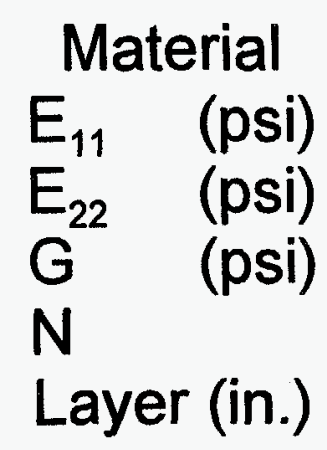

Static Load Conditions Bending Stress Deflection

Dynamic Load Conditions

Face Bending Stress

Core Shear Stress

Face Dimpling Stress

Face Wrinkling Stress

Deflection (psi)

(psi)

(psi)

(psi)

(in.)
Glass (G10)

$2.2 \mathrm{M}$

$2.7 \mathrm{M}$

$1.2 \mathrm{M}$

0.13

0.063
Honeycomb

$60.0 \mathrm{~K}$ $60.0 \mathrm{~K}$ $6.5 \mathrm{~K}$ 0.001 1.5
$16.4 \mathrm{~K}$

0.587

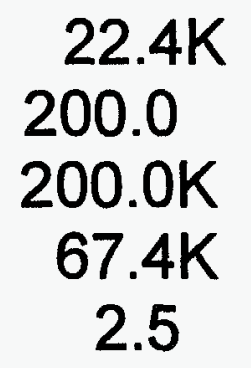




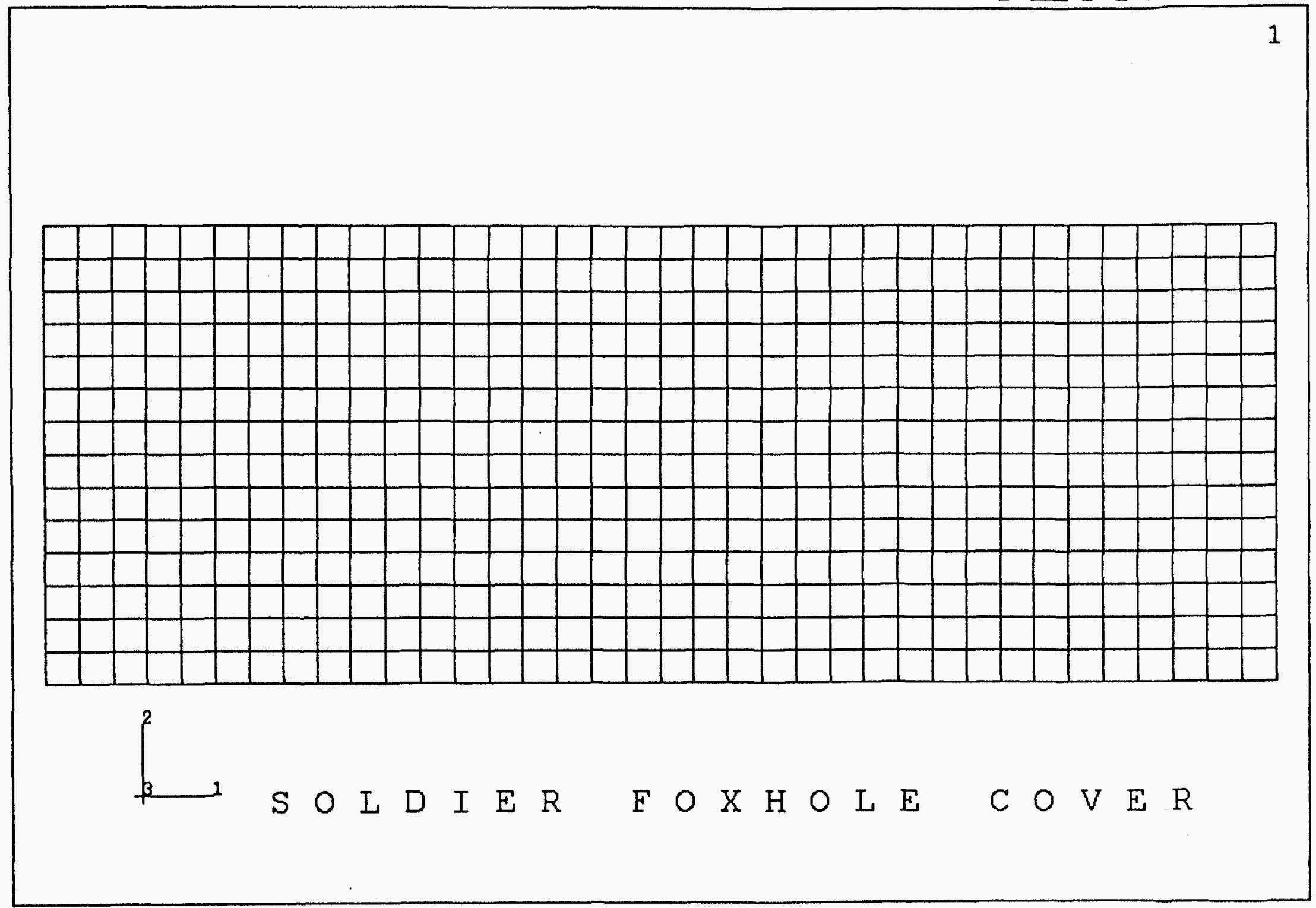

Finite Element Model of The Soldier Foxhole Cover With 3 Layers, The Two Outer Layers are 1/16" G-10 With The Middle Layer Being $11 / 2^{n}$ Honeycomb. 


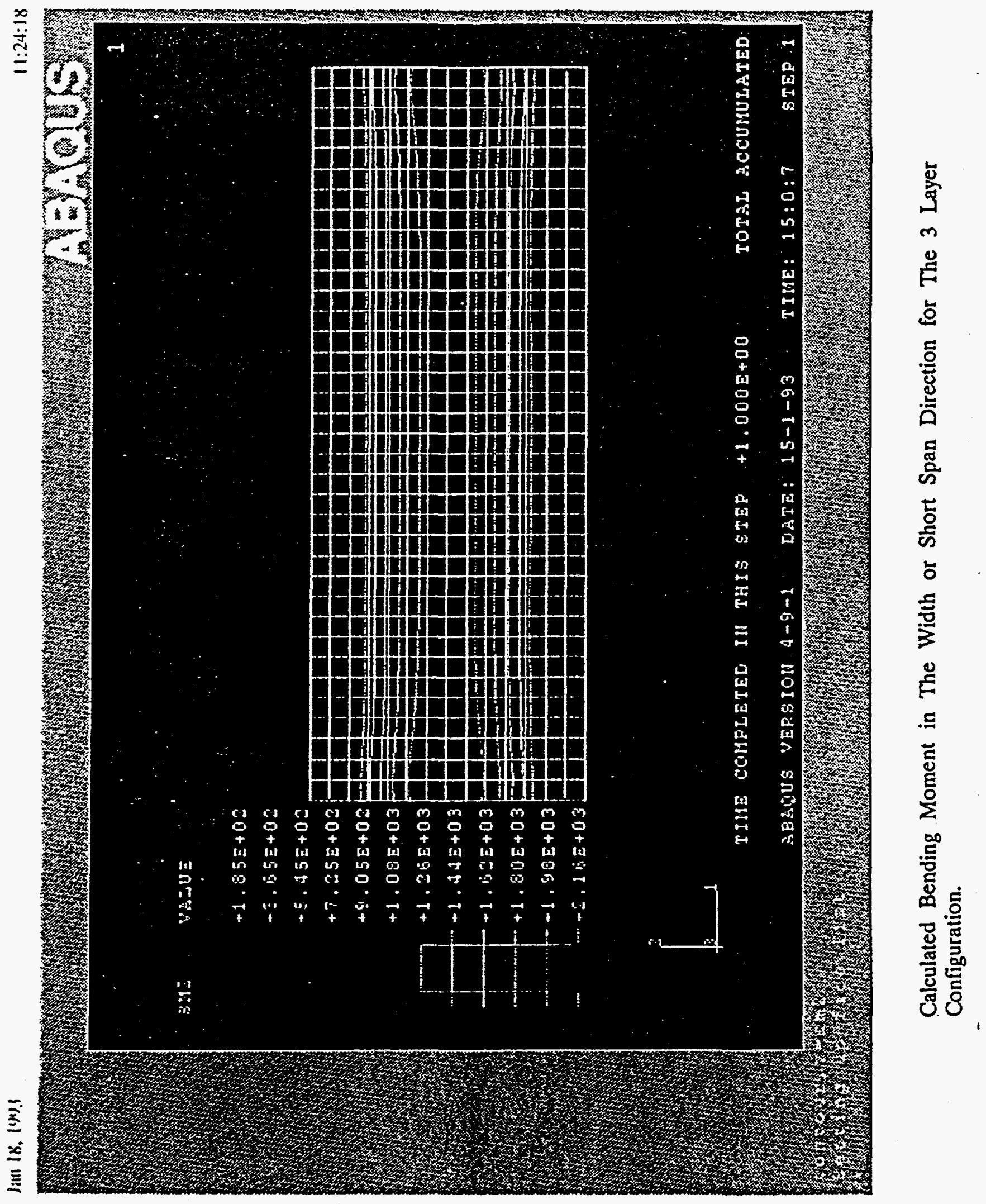




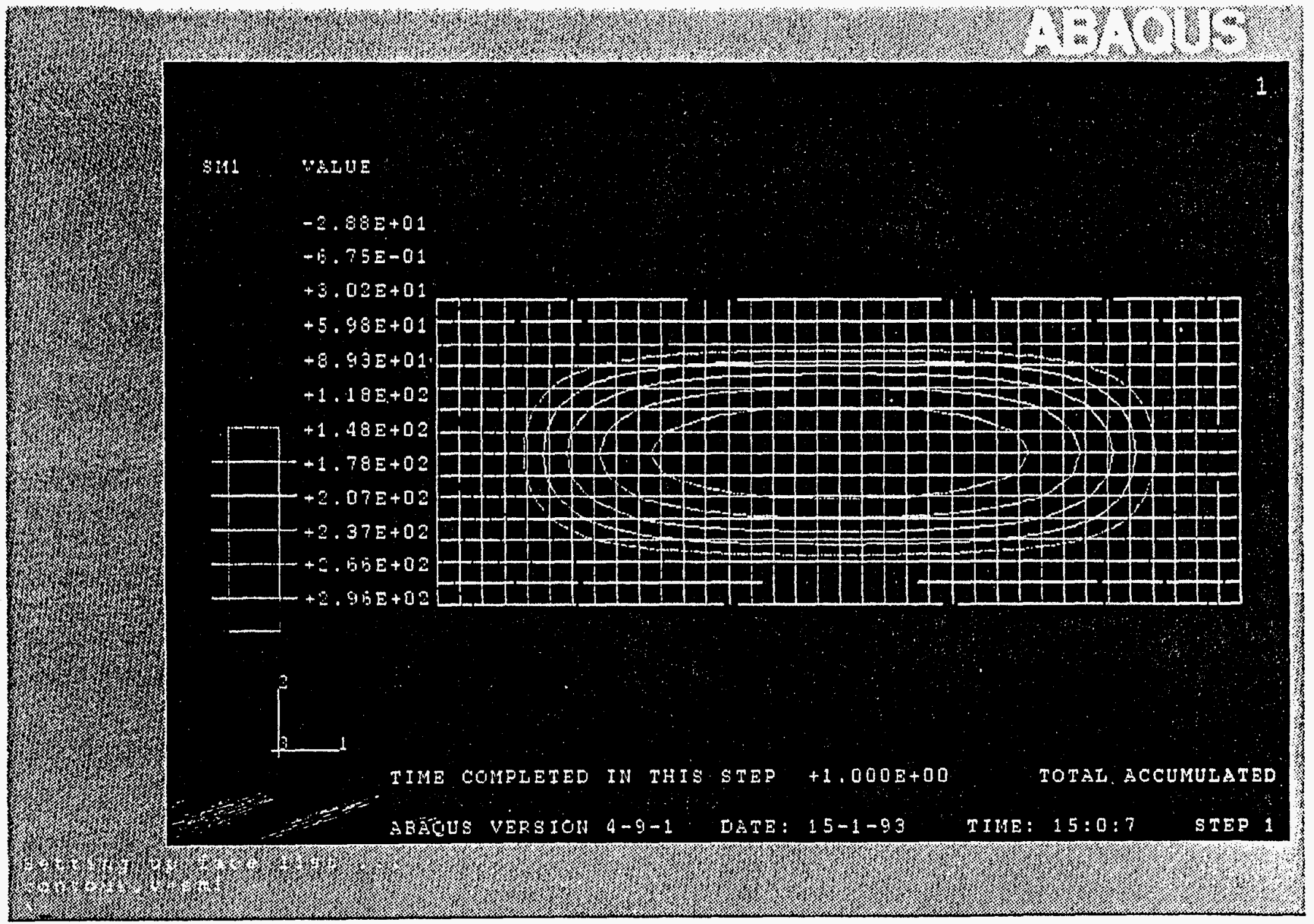

Calculated Bending Moment in The Length or Long Span Direction for The 3 Layer Configuration. 


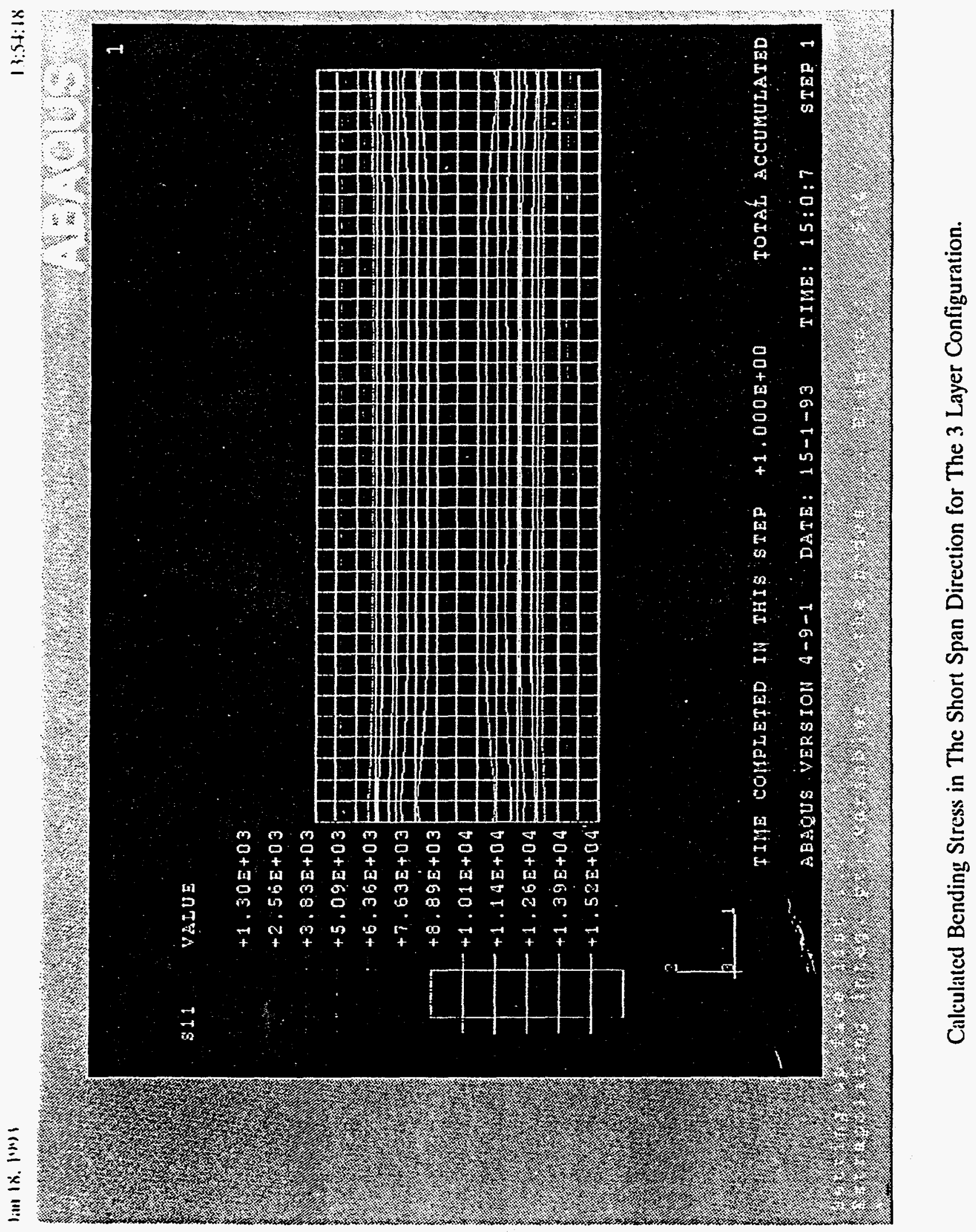




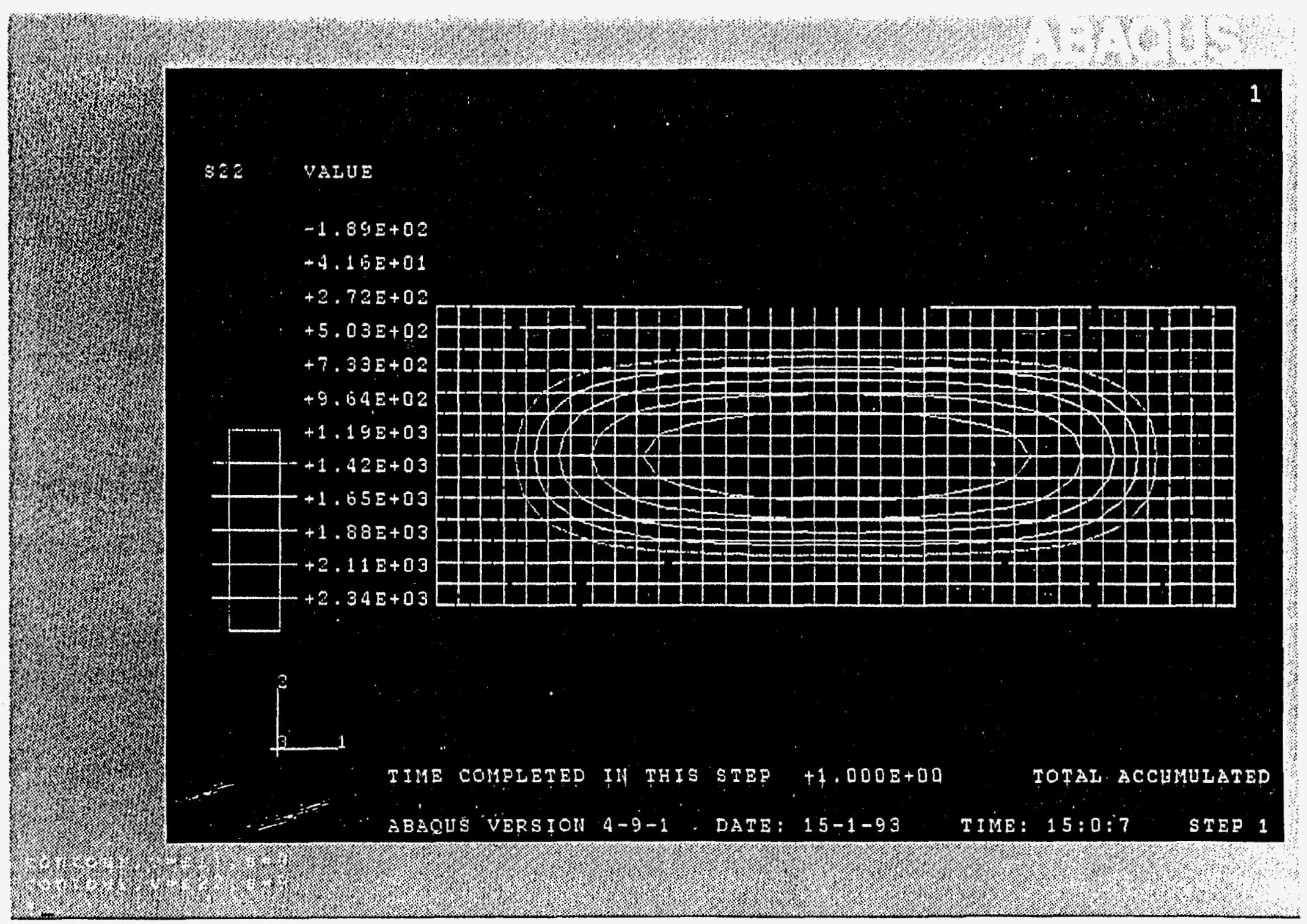

Calculated Bending Stress in The Long Span Direction for The 3 Layer Configuration. 


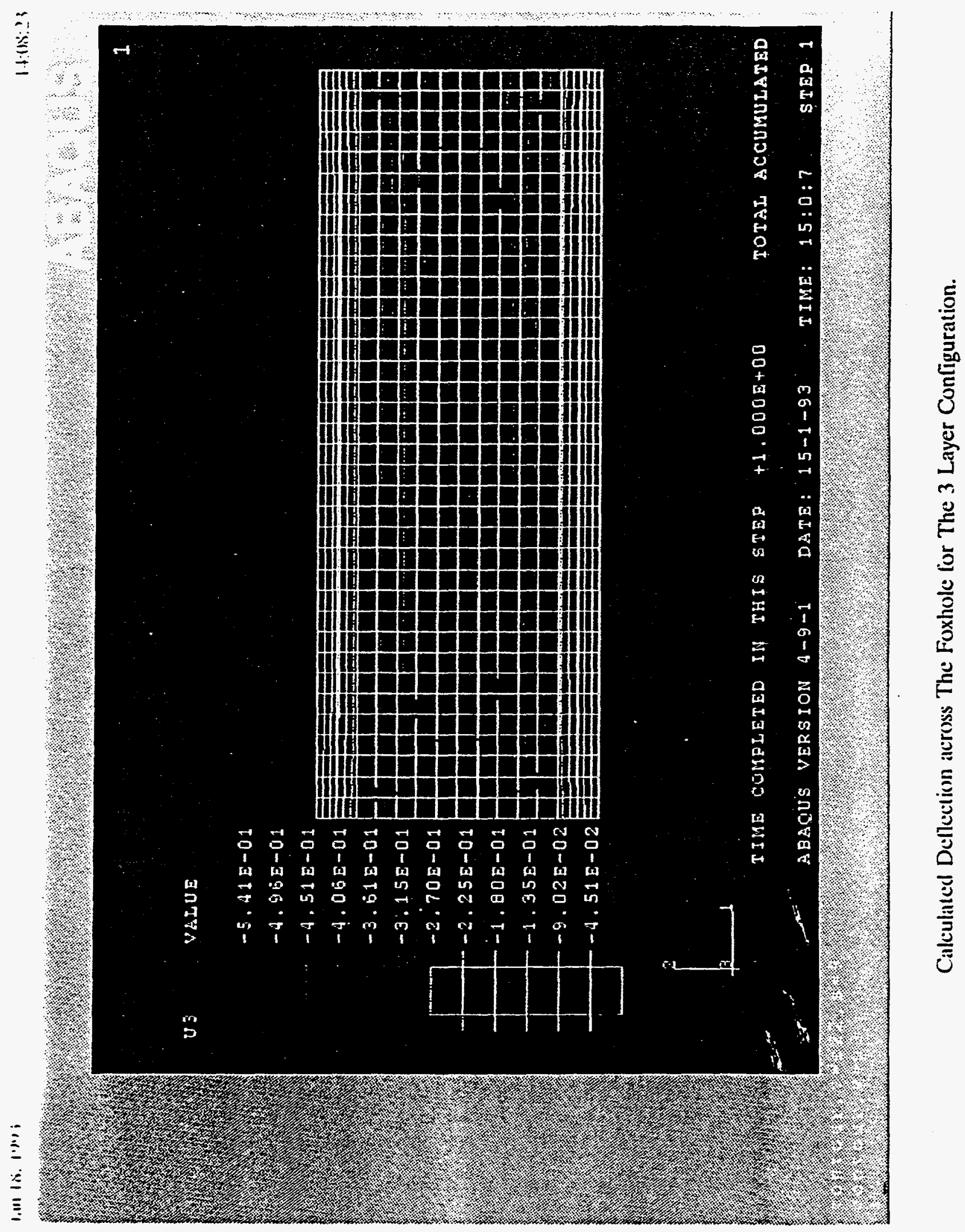




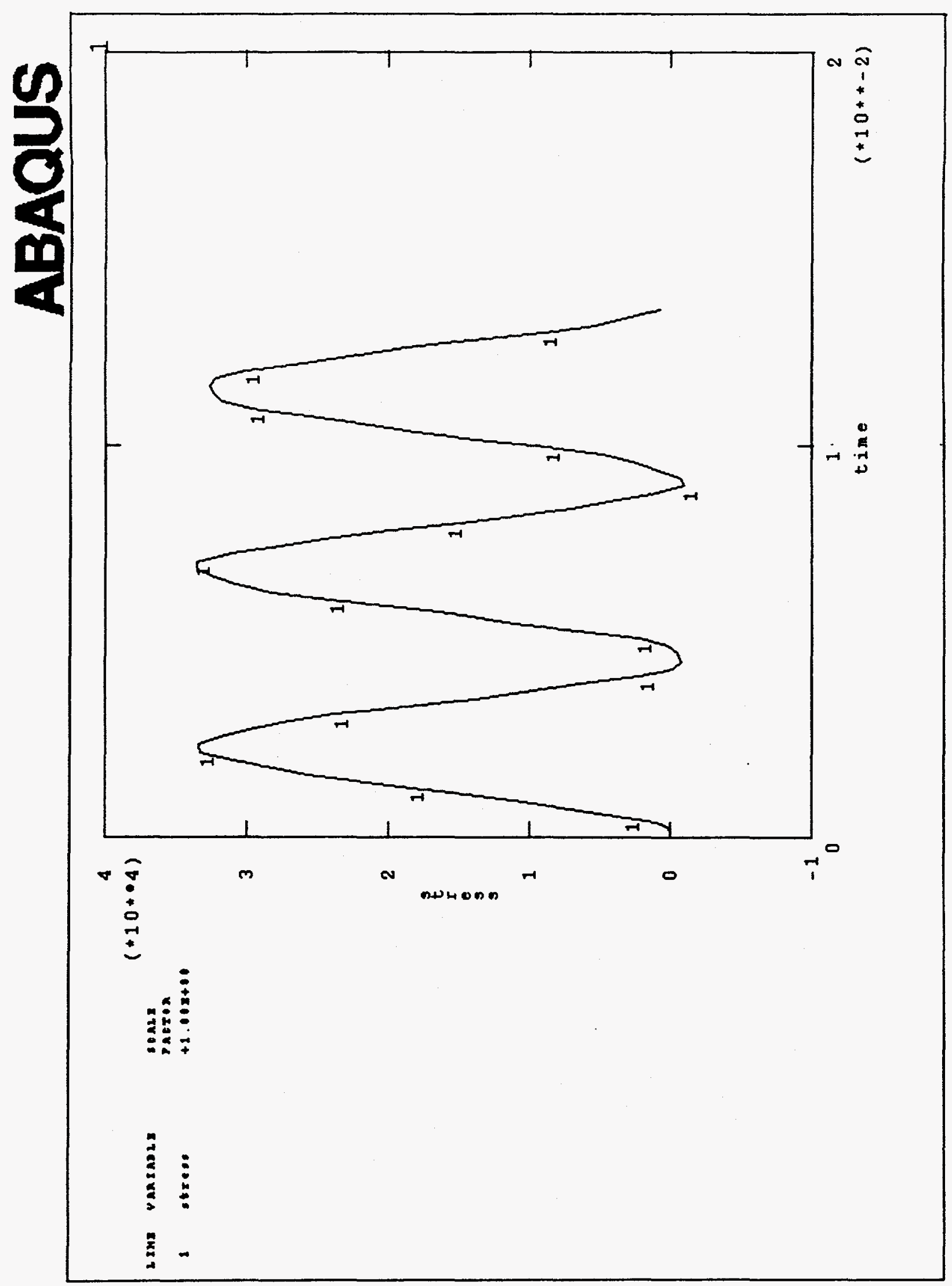

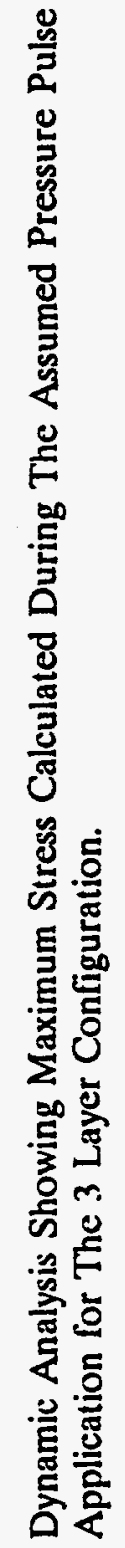


APPENDIX B. TECHNICAL DATA FOR

SOLDIER FIGHTING COVER MATERIALS

Carbon Fiber Prepreg

Aluminum Honeycomb

Structural Adhesive Film

Edge Sealing Compound

Neoprene-Coated Nylon Fabric

Structural Adhesive

B-1 


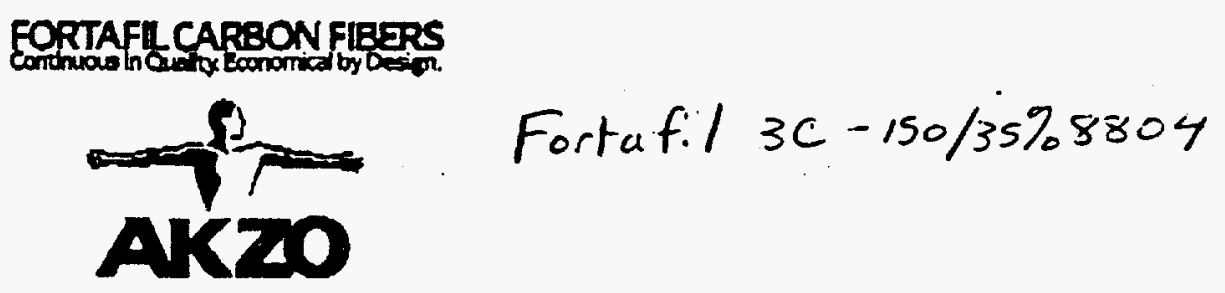

Technical Data Sheet 921C

\section{FORTAFIL 3(C) UNIDIRECTIONAL CARBON FIBER PREPREGS}

Fortafil 3(C) carbon tbers are avallable in anidirectlonal, pre-impregnated forms based on 250\% epoxy syotems. A wide range of combinations are offered with various resin contents, fiber areal weights, with or without glass serim bacidogs, and a seloction of widths. Product types are offered thst address differing resin tack requirements, resin flow, and resin gel time characteristics. Fortafl preprega are ideally suited for composito part thbication techniques such as vacuum bag/autociave molding, high and low pressure matched metal die compression molding and shrink tape consolidation of mandrel wrapped material.

Resln Systems

Type

Resin System Designations

Cure Conditions

Volatile Content

Shelf Life @ RT

Sheli Liso (c) Oo

Prepreg Characteristics

Width

Fiber Type

Fber Areal Weight (FAW) Range

Resin Content Range

Backings Avallable

Resin Designations

Gel Times 'F

250

275

300

Glass Transition Temperature $\left(T_{2}\right),{ }^{\text {, }}$ P

Resin Flow (w/bleeder) Avg. Wt.

Viscosity (during heat-up)

Tack
2S0\%

See below

1 bour Q $250^{\circ} \mathrm{F}$

Less than $0.2 \%$

30 Days (minimum)

12 Months (minimum) $12^{\prime \prime}$ or $24^{\prime \prime}$

F3(C) SOK

$120-190 \mathrm{~g} / \mathrm{m}^{2}$

$35-41 \%$

None or 108 glass serim

8601

125

6.0

3.1

310

$7.6 \%$

Figh

Intermediate
$9117 \quad 8804$

12.5

7.2

5.0

270

$10.3 \%$

Low

Intermedinte

$\uparrow$

Typical Laminate Properties (150 FAW, scrimless, unidirectional 60\% Dber volume)

Tensile Strength

Tensile Modulus

Flemiral Strength

Flexural Modulus

Shear Strength (short beam)

Cured Ply Thickness
290 bsi

$19 \mathrm{MSI}$

$280 \mathrm{ksi}$

$18 \mathrm{Mst}$

$13.5 \mathrm{kal}$
$290 \mathrm{lat}$

$19 \mathrm{Mri}$

$240 \mathrm{~kat}$

$18 \mathrm{MsI}$

125 ki

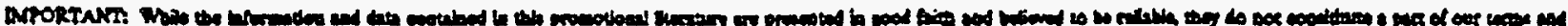

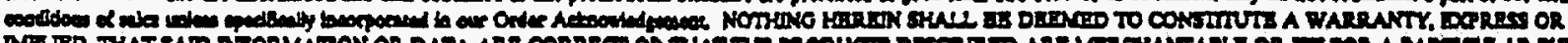

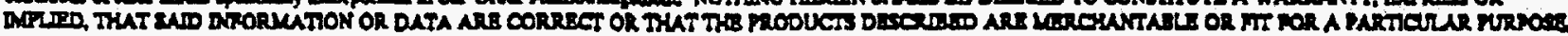

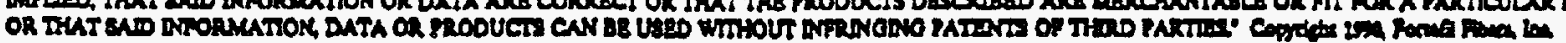

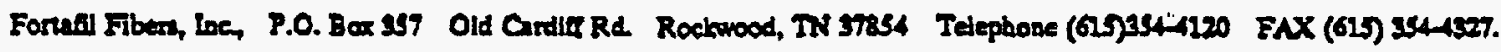




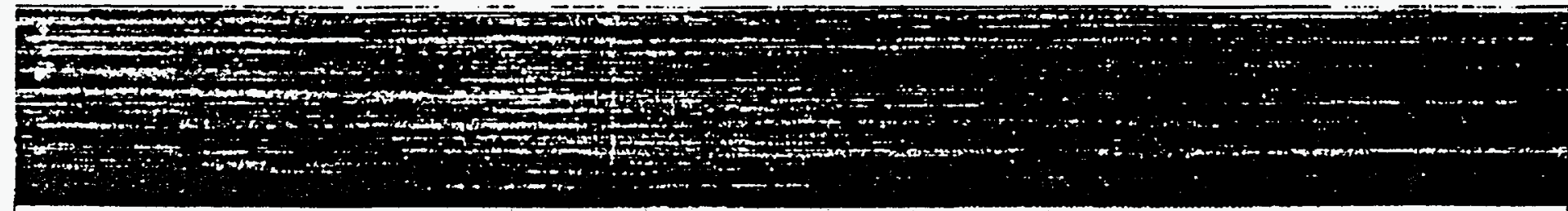

EORTAFILCAREONFERS

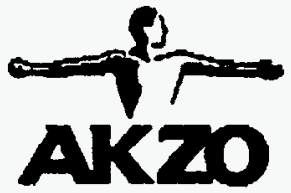

Technlcal Data Sheet $902 \mathrm{C3}$

FORTAFIL" 3(C) UNIDIRECTIONAL CARBON FIBER PREPREGS

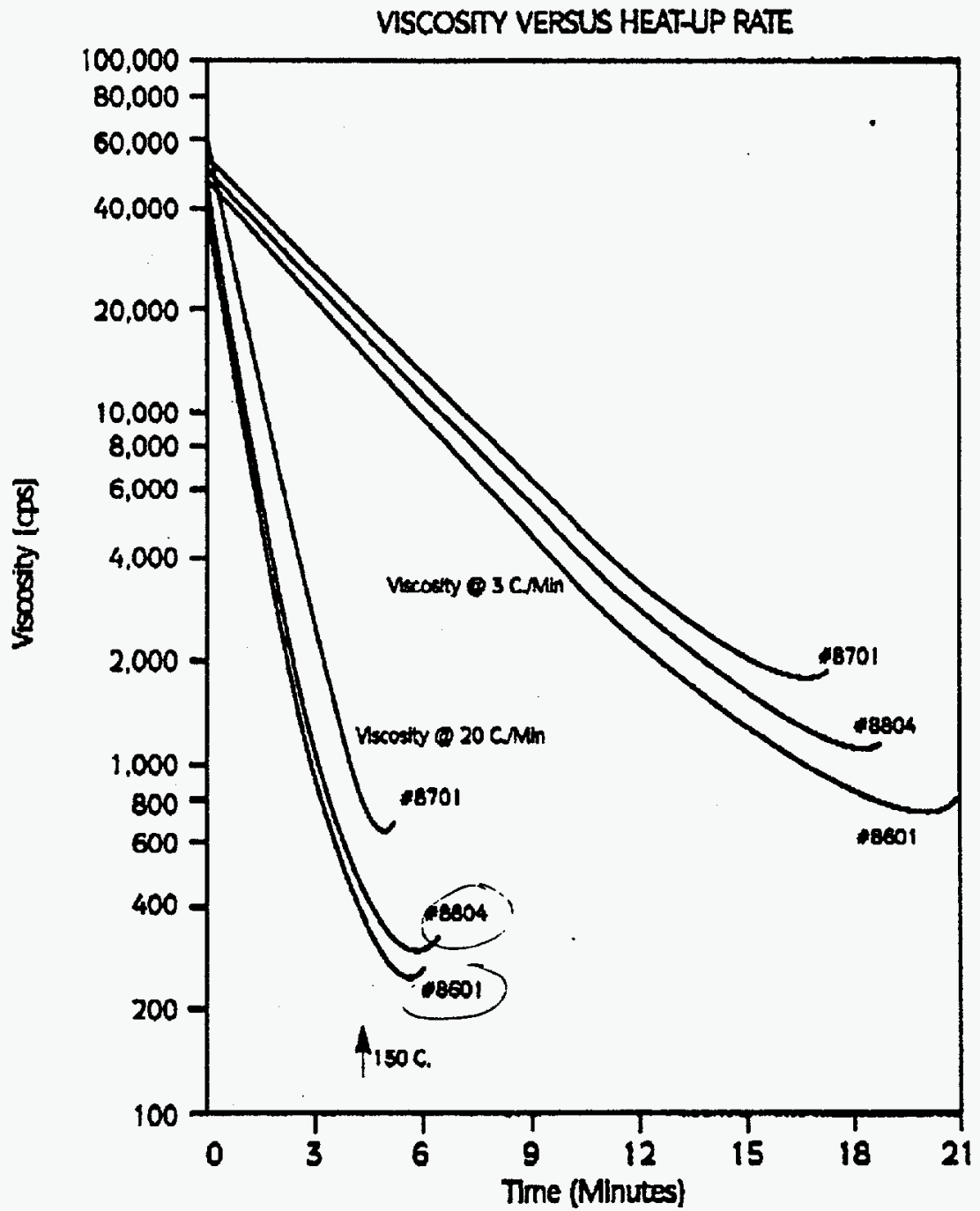

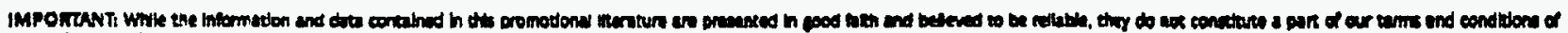

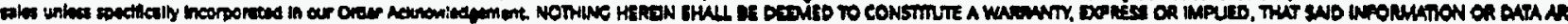

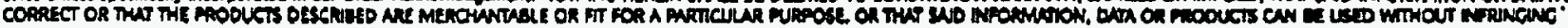

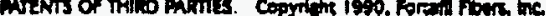

Fortafll Fibers, Inc. P.O. Box 357 Old Cardiff Rd. Rockwood, TN 37854 Telephone (615) 354-4120 FAX (615) 354-4327 


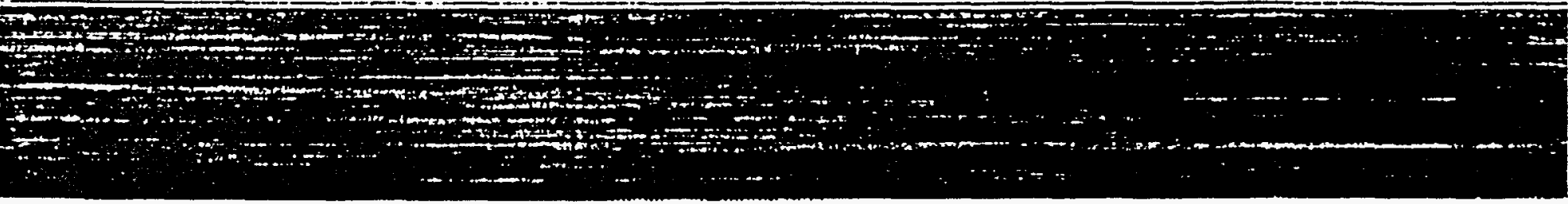

EORTAFLCARBON FRERS

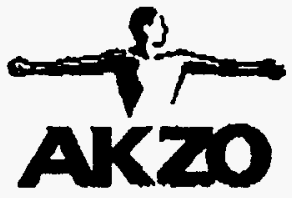

Technical Data Sheet $902 \mathrm{C} 1$

FORTAFIL PREPRECS - ALTERNATIVE CONDITIONS FOR COMPLETE CURING*

The 250\% epoxles are recommended to be cured at 250\%, for 1 hour. However, a complete cure can be effected for all Fortafif prepreg grades at reduced temperatures using extended tme periods as shown in the plot below. These are without regard to fiber and resin consolldation in the part or resin flow and loss. The use of temperatures higher than 250\%, with shortened cure tmes should be avolded.

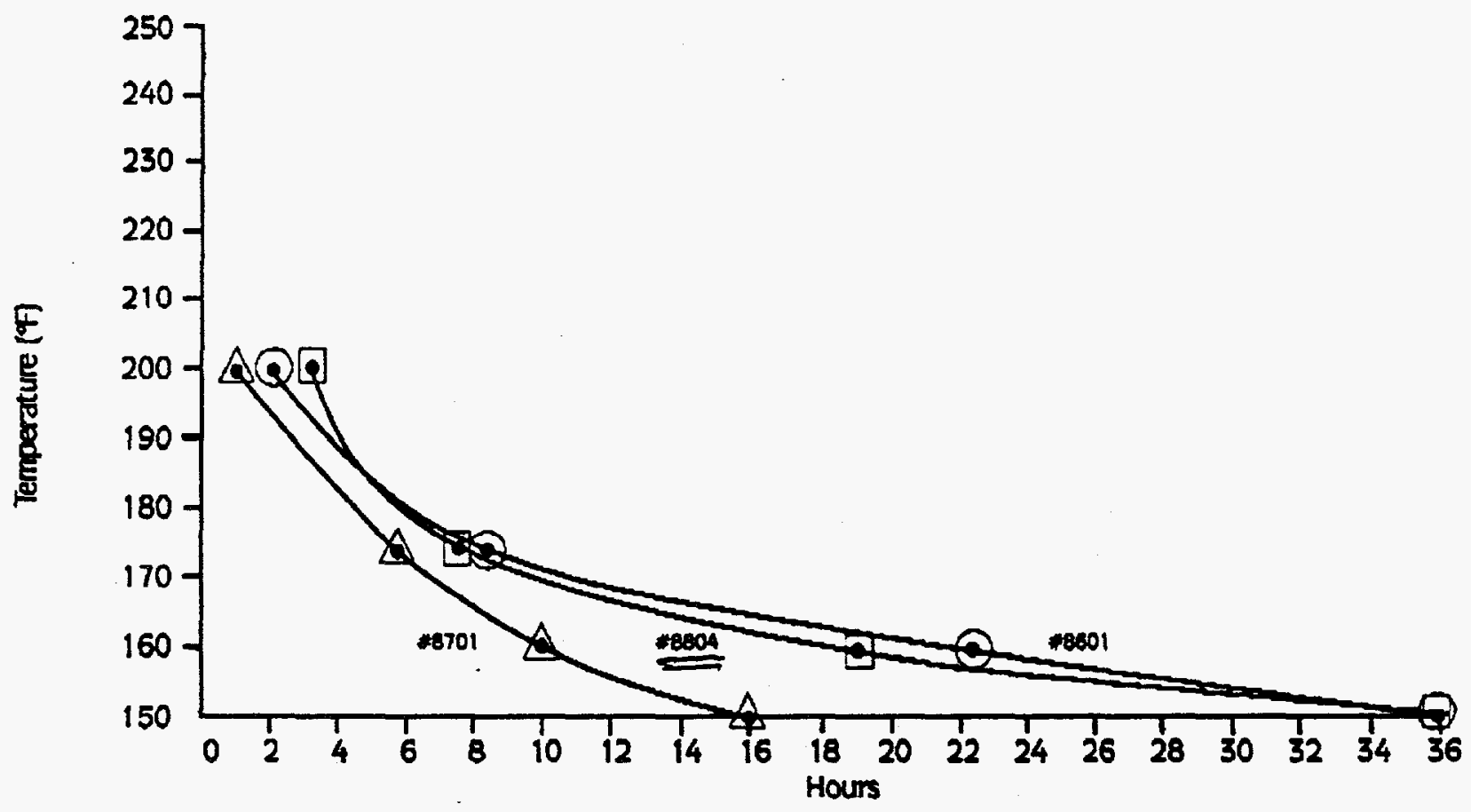

-Minimum times required at each temperature to achieve a Barcol hardness of 65 (typical after I hour at 250\%.).

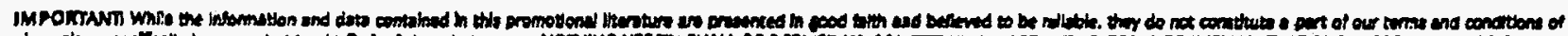

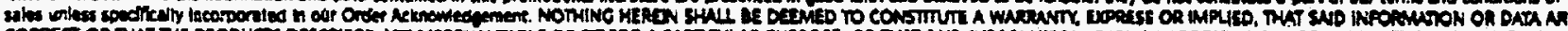

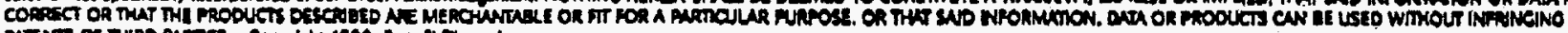

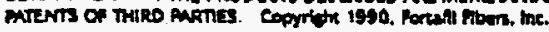

Fortafil Fibers, Ine. P.O. Box 357 Old Cardiff Rd. Rockwood. TN 37854 Telephone (615) 354-4120 FAX (615) 354-4327

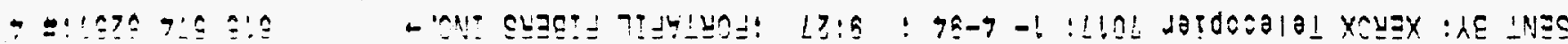




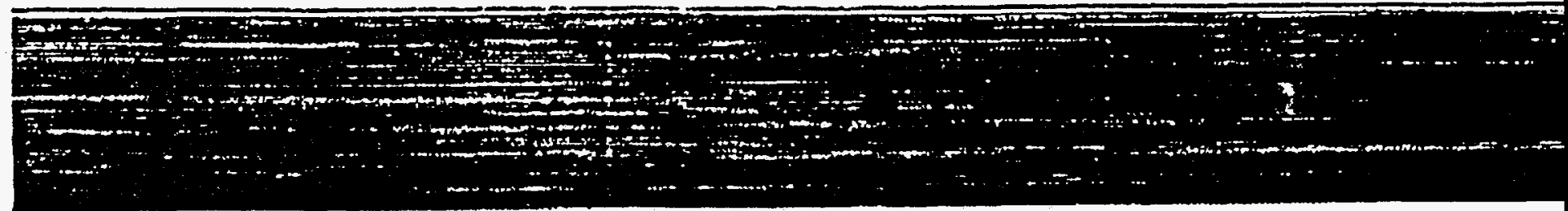

FORTAFILCARBON FIRERS

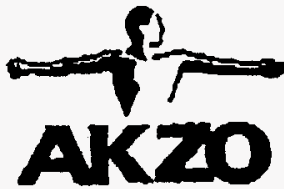

Technical Data Sheet $902 \mathrm{C} 2$

FORTAFIL 3(C) UNIDIRECTIONAL CARBON FIBER PREPREGS

PREPREC COMPONENT \& SUMMARY WEIGHTS/VIELDS

\begin{tabular}{|c|c|c|c|c|c|c|c|c|c|c|c|c|c|c|c|}
\hline & & & & & & & & & & & & & $N$ & & AW \\
\hline & *itit & $\begin{array}{l}\text { Total } \\
\mathrm{g} / \mathrm{m}^{2}\end{array}$ & Geld & $\begin{array}{l}\text { Total } \\
\mathrm{g} / \mathrm{m}^{2}\end{array}$ & $\begin{array}{l}\text { Yield } \\
\mathrm{t}^{2} / \mathrm{b} \text {. }\end{array}$ & & $\begin{array}{l}\text { Yeyd } \\
t^{2} / b^{2} .\end{array}$ & & $\begin{array}{l}\text { Yiejd } \\
f^{2} / j b .\end{array}$ & $\mathrm{g} / \mathrm{m}^{2}$ & e & $\begin{array}{l}\text { lot } \\
\text { g/n }\end{array}$ & $\begin{array}{l}\text { Yield } \\
\mathrm{t}^{2} / \mathrm{b} \text {. }\end{array}$ & $\begin{array}{l}\text { Total } \\
\mathrm{g} / \mathrm{m}^{2}\end{array}$ & $\begin{array}{l}\text { Yield } \\
\pi^{2} / 1 \mathbf{b} \text {. }\end{array}$ \\
\hline & $\begin{array}{l}32 \\
34 \\
36 \\
38 \\
40 \\
42\end{array}$ & $\begin{array}{l}181.8 \\
187.5 \\
193.5 \\
200.0 \\
206.9\end{array}$ & $\begin{array}{l}7.66 \\
5.86 \\
6.04 \\
5.23 \\
4.41 \\
3.60\end{array}$ & $\begin{array}{l}03.1 \\
09.7 \\
16.7 \\
24.1\end{array}$ & $\begin{array}{l}25.53 \\
24.78 \\
24.04 \\
23.28 \\
22.53 \\
21.79\end{array}$ & $\begin{array}{l}05.8 \\
12.1 \\
18.7 \\
25.8 \\
33.3 \\
41.4\end{array}$ & $\begin{array}{l}23.72 \\
23.02 \\
22.32 \\
21.62 \\
20.93 \\
20.23\end{array}$ & $\begin{array}{l}13.2 \\
19.7 \\
26.6 \\
33.9 \\
41.7 \\
50.0\end{array}$ & $\begin{array}{l}22.90 \\
22.22 \\
21.55 \\
20.87 \\
20.20 \\
19.53\end{array}$ & $\begin{array}{l}20.6 \\
27.3 \\
34.4 \\
41.9 \\
50.0 \\
58.6\end{array}$ & $\begin{array}{l}22.13 \\
21.48 \\
20.83 \\
20.18 \\
19.53 \\
18.88\end{array}$ & $\begin{array}{l}42.6 \\
50.0 \\
57.8 \\
66.1 \\
75.0 \\
84.5\end{array}$ & $\begin{array}{l}20.12 \\
19.53 \\
18.94 \\
18.35 \\
17.75 \\
17.16\end{array}$ & $\begin{array}{l}279.4 \\
287.9 \\
296.9 \\
306.4 \\
316.7 \\
327.6\end{array}$ & \begin{tabular}{|l|}
17.47 \\
16.96 \\
16.44 \\
15.94 \\
15.42 \\
14.90
\end{tabular} \\
\hline 04 & $\begin{array}{l}32 \\
34 \\
36 \\
38 \\
40 \\
42\end{array}$ & $\begin{array}{l}11.6 \\
18.2 \\
25.2 \\
32.8 \\
40.8\end{array}$ & $\begin{array}{l}23.07 \\
22.37 \\
21.68 \\
20.97 \\
20.28\end{array}$ & $\begin{array}{l}41.4 \\
49.4 \\
58.0\end{array}$ & $\begin{array}{l}22.18 \\
21.53 \\
20.88 \\
20.22 \\
19.58 \\
18.92\end{array}$ & $\begin{array}{l}34.8 \\
41.9 \\
49.5 \\
57.5 \\
66.1 \\
75.3\end{array}$ & $\begin{array}{l}20.79 \\
20.18 \\
19.57 \\
18.96 \\
18.35 \\
17.73\end{array}$ & $\begin{array}{l}42.1 \\
49.5 \\
57.3 \\
65.6 \\
74.4 \\
83.9\end{array}$ & $\begin{array}{l}20.17 \\
19.57 \\
18.98 \\
18.38 \\
17.79 \\
17.20\end{array}$ & $\begin{array}{l}49.5 \\
57.1 \\
65.1 \\
73.6 \\
32.8 \\
92.5\end{array}$ & $\begin{array}{l}18.99 \\
18.42 \\
17.84 \\
17.26 \\
16.69\end{array}$ & $\begin{array}{l}271.6 \\
279.8 \\
288.5 \\
297.8 \\
307.8 \\
318.4\end{array}$ & $\begin{array}{l}17.98 \\
17.45 \\
16.92 \\
16.39 \\
15.86 \\
15.33\end{array}$ & $\begin{array}{l}308.3 \\
317.7 \\
327.6 \\
338.2 \\
349.4 \\
361.5\end{array}$ & $\begin{array}{l}15.84 \\
15.37 \\
14.90 \\
14.44 \\
13.97 \\
13.51\end{array}$ \\
\hline 88 & $\begin{array}{l}32 \\
34 \\
36 \\
38 \\
40 \\
42\end{array}$ & $\begin{array}{l}47.8 \\
55.3 \\
53.2 \\
71.7 \\
30.8 \\
30.5\end{array}$ & $\begin{array}{l}19.70 \\
19.12 \\
18.55 \\
17.97 \\
17.39 \\
16.81\end{array}$ & $\begin{array}{l}62.5 \\
70.4 \\
78.9 \\
87.9 \\
97.5 \\
07.7\end{array}$ & $\begin{array}{l}18.60 \\
18.06 \\
17.51 \\
16.96 \\
16.41 \\
15.87\end{array}$ & $\begin{array}{l}77.2 \\
85.6 \\
94.5 \\
04.0 \\
14.1 \\
24.9\end{array}$ & $\begin{array}{l}17.61 \\
17.09 \\
16.58 \\
16.06 \\
15.54 \\
15.03\end{array}$ & $\begin{array}{l}284.5 \\
293.1 \\
302.3 \\
312.1 \\
322.5 \\
333.6\end{array}$ & $\begin{array}{l}17.16 \\
16.66 \\
16.15 \\
15.64 \\
15.14 \\
14.63\end{array}$ & $\begin{array}{l}291.9 \\
300.7 \\
310.1 \\
320.1 \\
330.8 \\
342.2\end{array}$ & $\begin{array}{l}16.24 \\
15.74 \\
15.25 \\
14.76 \\
14.27\end{array}$ & $\begin{array}{l}323.4 \\
333.6 \\
344.3 \\
355.8 \\
368.1\end{array}$ & $\begin{array}{l}15.55 \\
15.10 \\
14.64 \\
14.18 \\
13.72 \\
13.26\end{array}$ & $\begin{array}{l}350.7 \\
361.3 \\
372.6 \\
384.6 \\
397.5 \\
411.2\end{array}$ & $\begin{array}{l}13.51 \\
13.10 \\
12.70 \\
12.28 \\
11.87\end{array}$ \\
\hline
\end{tabular}

NOTES: $\quad \int$ Yield does not Indude paper welght.

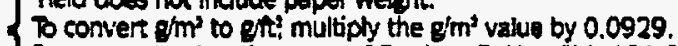

Paper areai weight (average of Daubert \& Avrosh) is $101.8 \mathrm{e} / \mathrm{m}^{2}$ (48.0 $\mathrm{t}^{2} / \mathrm{h}$ ).

\begin{tabular}{|c|c|c|c|c|}
\hline & \multicolumn{4}{|c|}{ GLASS SCRMM } \\
\hline & \multicolumn{2}{|c|}{ Welont } & \multicolumn{2}{|c|}{ Thidknes } \\
\hline Tpe & $0 e 1 d^{2}$ & $8 \mathrm{~m}^{2}$ & Incthes & $\mathrm{mm}$ \\
\hline 104 & 0.58 & 19.66 & 0.0012 & 0.0305 \\
\hline 106 & 0.73 & 24.75 & 0.0015 & 0.0381 \\
\hline 108 & 1.43 & 48.48 & 0.0023 & 0.0584 \\
\hline
\end{tabular}

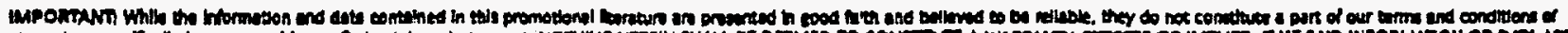

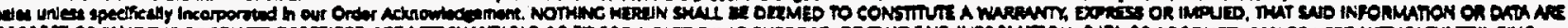

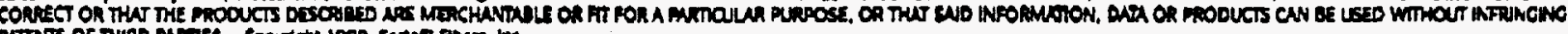

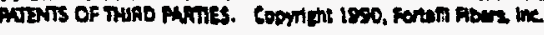

Fortafll Flbers, Inc. P.O. Box 357 Old Cardff Rd. Rockwood, TN 37854 Telephone (615) 354-4120 FAX (615) $354-4327$

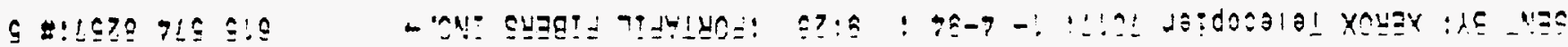




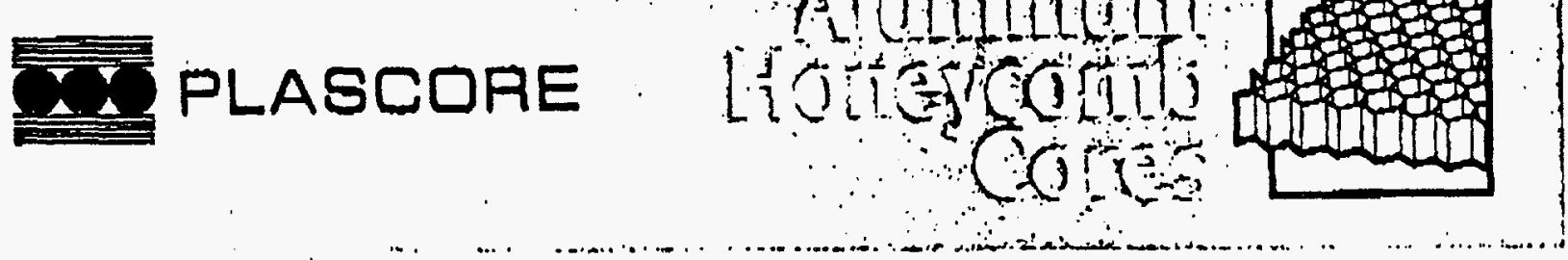

\section{PAMG 5052 Aluminum Honeycomb}

Description:

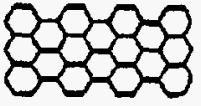

Features:

Appllcations:

Availability:
PAMG 5052 aluminum honeycomb is a lightweight core material which offers superior strenth and corrosion resistance over commerclal grade aluminum core. PAMG 3052 core Is made from 5052 aluminum alloy foll and meets all the requirements of MIL-C-7438.

- Elevated Use Temperatures

- High Thermal Conductivity

- Flame Resistant

- Excellent Molsture and Corrosion Resistance

- Fungl Resistant

- Low Welght / HIgh Strength

PAMG 5052 honeycomb uses include aireraft floors. sircraft leading and tralling edges. missile wings. tan casings, fuel cells, fuselage components. helicopter rotor blades, and navy bulkhead joiner panels. PAMG 5052 aluminum honeycomb is suitable for applicaJons where materials conforming to MIL-C-7438 are required.

PAMG 5052 honeycomb is available in four forms: unexpanded blocks. unexpanded block slices, untrimmed expanded sheets and cut to size expanded sheets. PAMG 3052 core is also avallable with or without cell perforations to faclititate cell venting for certain applications.

Sheer Length (W): 150" max

Sheet Width (L): $60^{\prime \prime} \max$

Tolerances:

$$
\begin{array}{ll}
\text { Length: } & \pm .032 * \\
\text { Width: } & \pm .032 * \\
\text { Thickness: } & \pm .005 \\
\text { Density: } & \pm 10 \% \\
\text { Cell size: } & \pm 10 \%
\end{array}
$$

-Varies with cell size

Special dimensions. cell sizes. tolerances and mechanical properties can be provided.

Structural data on reverse side. 
Typical Property Values:

\begin{tabular}{|c|c|c|c|c|c|c|c|c|}
\hline \multicolumn{3}{|c|}{ Plascore Honeycomb Designation } & \multicolumn{2}{|c|}{ Bare Compressive } & \multicolumn{4}{|c|}{ Plate Shear } \\
\hline $\begin{array}{l}\text { Cell } \\
\text { Size }\end{array}$ & $\begin{array}{l}\text { Foil } \\
\text { Gauge }\end{array}$ & $\begin{array}{c}\text { Nominal } \\
\text { Density PCF }\end{array}$ & $\begin{array}{l}\text { Strength } \\
\text { PSP }\end{array}$ & $\begin{array}{l}\text { Modulus } \\
\text { KSI }\end{array}$ & \multicolumn{2}{|c|}{ Strength PSI } & \multicolumn{2}{|c|}{ Modulus KSI } \\
\hline $1 / 8$ & .0007 & 3.1 & 270 & 75 & 210 & 130 & 45 & 22 \\
\hline $1 / 8$ & .001 & 4.5 & 520 & 150 & 340 & 220 & 70 & 31 \\
\hline $1 / 8$ & .0015 & 6.1 & 870 & 240 & 505 & 320 & 98 & 41 \\
\hline $1 / 8$ & .002 & 8.1 & 1400 & 350 & 725 & 455 & 135 & 54 \\
\hline $3 / 16$ & .001 & 3.1 & 270 & 75 & 210 & 130 & 45 & 22 \\
\hline $3 / 16$ & .0015 & 4.4 & 500 & 145 & 330 & 215 & 68 & 30 \\
\hline $3 / 16$ & .002 & 5.7 & 770 & 220 & 460 & 300 & 90 & 38 \\
\hline $3 / 16$ & .0025 & 6.9 & 1080 & 285 & 590 & 375 & 114 & 46 \\
\hline $3 / 16$ & .003 & 8.1 & 1400 & 350 & 725 & 455 & 135 & 54 \\
\hline $1 / 4$ & .0007 & 1.6 & 85 & 20 & 85 & 50 & 21 & 11 \\
\hline $1 / 4$ & .001 & 2.3 & 165 & 45 & 140 & 85 & 32 & 16 \\
\hline $1 / 4$ & .0015 & 3.4 & 320 & 90 & 235 & 150 & 50 & 24 \\
\hline $1 / 4$ & .002 & 4.3 & 480 & 140 & 320 & 210 & 66 & 29 \\
\hline $1 / 4$ & .0025 & 5.2 & 670 & 190 & 410 & 265 & 82 & 35 \\
\hline $1 / 4$ & .003 & 6.0 & 850 & 235 & 495 & 315 & 96 & 40 \\
\hline $1 / 4$ & .004 & 7.9 & 1360 & 340 & 700 & 440 & 130 & 52 \\
\hline $3 / 8$ & .0007 & 1.0 & 30 & 10 & 45 & 30 & 12 & 7 \\
\hline $3 / 8$ & .0015 & 2.3 & 165 & 45 & 140 & 85 & 32 & 16 \\
\hline $3 / 8$ & .002 & 3.0 & 260 & 70 & 200 & 125 & 43 & 21 \\
\hline 318 & .0025 & 3.7 & 370 & 105 & 260 & 170 & 55 & 26 \\
\hline $3 / 8$ & .003 & 4.2 & 460 & 135 & 310 & 200 & 65 & 29 \\
\hline $3 / 8$ & .004 & 5.4 & 720 & 200 & 430 & 280 & 86 & 36 \\
\hline
\end{tabular}

How to Specify Plascore Honeycomb Cores:

Plascore PAMG 5052 aluminum honeycomb is specified by using product parameters in the following manner:

PAMG-Density-Cell Size-Foil Thickness-Perforated-Alloy

Example: PAMG-3.0-3/8-.002-P-5052

- PAMG designates Aluminum Military Grade

- 3.0 is nominal density in pounds per cublic foot

- $3 / 8$ is the cell size in inches

- "P indicates that the cell walls are to be perforated. If no perforation is desired omit the "P".

- 5052 designates the alloy of the foil

-.002 designates the foil thickness in inches

IMPORTant Nomes: The information herein recarding our product. equipment and processes is believed to be retiable end to the best of aur knowledp. We do not warment the secursey and completanese of any such information, whether expresed or implied. including warrancies of fieness for a particular purpose. It is the user's or purcheser's responsibility to underake aufficient testing to verfy the suirebility of our producte for their own particuler purpose.

The informstion contained hersin shall not be conserued as induce. ment, parmission or recommendation to iniringe upoin amy patent rights or other rights of third partes.

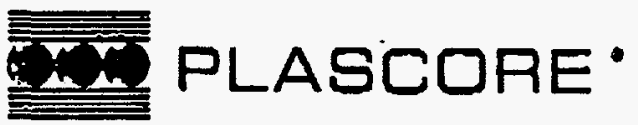

PLASCORE. INC. - B15 N. FAIFVIEW ST. • ZEELAND, MICHIGAN 48484 • PHONE (818) 772-1220 • FAX (616) 772.5508 


\section{Scotch-Weld}

\section{Structural Adhesive Film AF-163-2}

\section{Introduction:}

Scotch-Weld Brand AF-163-2 designates a family of thermosetting modified epoxy structural adhesives in film form which are available in a variety of weights with or without a supporting carrier. AF-163-2 films are designed for both solid panel and honeycomb sandwich constructions. These products offer the following advantageous properties.

1. High bond strengths from $-67^{\circ} \mathrm{F}$. to $250^{\circ} \mathrm{F}$.

2. High fracture toughness and peel strengths.

3. Excellent resistance to high moisture environments before and after curing.

4. Short cure times as low as $225^{\circ} \mathrm{F}$. (90 min).

5. Freedom from volatile by-products during cure which permits low pressure bonding.

6. Vacuum cure capability.

7. Bond line heat up rates as low as $1^{\circ} \mathrm{F}$./minute can be tolerated.

8. X-ray opaque resin system allows use of $x$-ray NDT methods.

9. Improved shop open time and long shelf life.

10. Limited self-extinguishing characteristics.

\section{Description:}

The following AF-163-2 products are included in this data sheet:

\begin{tabular}{|c|c|c|c|c|}
\hline Product & Weight Lbs./Ft." & Color & $\begin{array}{l}\text { Nominal } \\
\text { Thickness - mils }\end{array}$ & Base \\
\hline$A F-163-2 K$ & 0.045 & Yellow & 7.5 & Modified Epoxy \\
\hline AF-163-2K & 0.06 & Red & 9.5 & Modified Epoxy \\
\hline AF-163-2K & 0.085 & Blue & 13 & Modified Epoxy \\
\hline AF-163-2M & 0.045 & Yellow & 7.5 & Modified Epoxy \\
\hline AF-163-2M & 0.06 & Red & 9.5 & Modified Epoxy \\
\hline AF-163-2M & 0.085 & Blue & 13 & Modified Epoxy \\
\hline$A F-163-2 O S T$ & 0.03 & Green & 5.5 & Modified Epoxy \\
\hline$A F-163-2 O S T$ & 0.06 & Red & 9.5 & Modified Epoxy \\
\hline$A F-163-2 U$ & 0.03 & Red & 5.5 & Modified Epoxy \\
\hline$A F-163-2 U$ & 0.06 & Red & 9.5 & Modified Epoxy \\
\hline
\end{tabular}

Code: $\quad K=$ knit supporting carrier

$M=$ non-woven supporting carrier

OST = one side tacky with non-woven carrier on low tack surface

$U=$ unsupported film 


\section{Contents:}

\section{Product Performance}

Cured Free Film Properties $. . \ldots \ldots \ldots \ldots \ldots \ldots \ldots \ldots \ldots \ldots \ldots \ldots \ldots, \ldots \ldots \ldots$

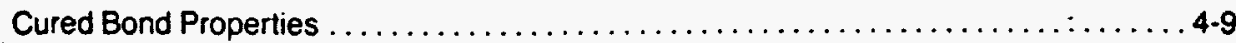

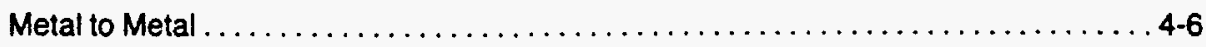

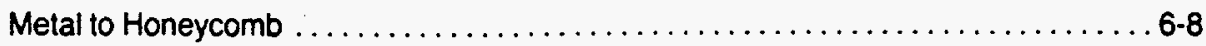

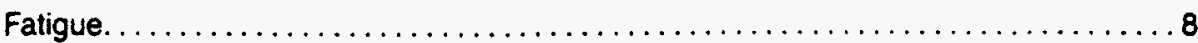

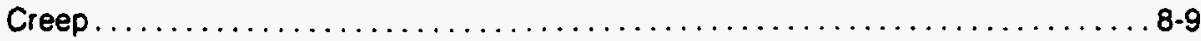

Performance on other Substrates .................................. 9

Environmental Exposure

Metal to Metal..............................................

Metal to Honeycomb .......................................... 11

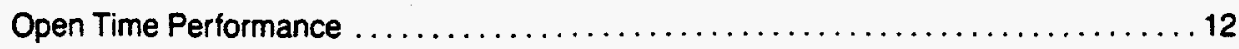

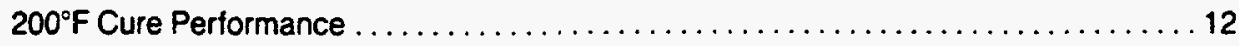

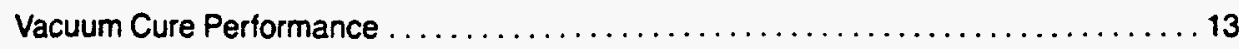

Effect of Rise Rate. . . . . . . . . . . . . . . . . . . . . . . . . . . . . . . . . 13

\section{Product Application}

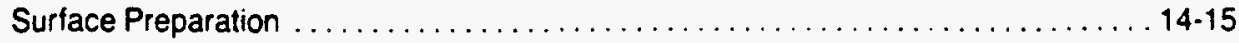

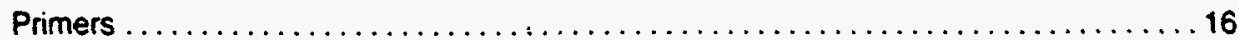

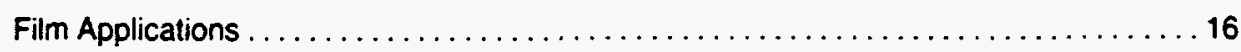

Cure Conditions Characteristics ................................ 16-17

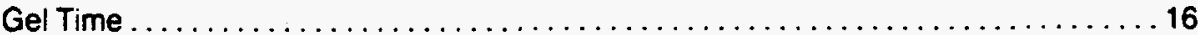

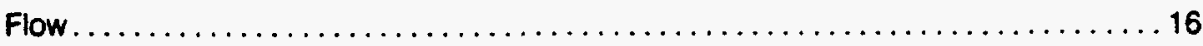

Storage................................................... 19

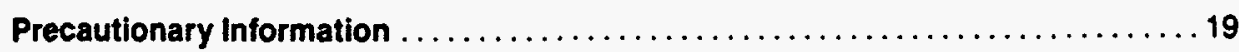




\section{Product Performance:}

The following results have been obtained by $3 M$ Laboratories under the conditions specified with test specimens prepared using the general methods described in the product application section.

I Typical Cured Free Film Properties:

A. Glass Transition Temperature - unsupported

Method: Dupont 1090 DMA at $5^{\circ} \mathrm{C} . /$ minute

Cure: 60 minutes at $250^{\circ} \mathrm{F}$.

dry: $108^{\circ} \mathrm{C}\left(226^{\circ} \mathrm{F}\right.$. $)$

'wet: $82^{\circ} \mathrm{C}\left(180^{\circ} \mathrm{F}\right)$

-after 14 day immersion in water at $70^{\circ} \mathrm{C}$.

B. Tensile Strength and Modulus - unsupported

Cured: Free Film Strips approx. $1 / 4^{\prime \prime} \times 3^{\prime \prime} \times .01^{\prime \prime}$ Thick

Cure: 90 minutes at $235^{\circ} \mathrm{F}$.

Temperature

Ultimate Strength - PSI

Modulus PSI

$\begin{array}{rrr}-67^{\circ} \mathrm{F} . & 11,000 & 2.3 \times 10^{5} \\ 75^{\circ} \mathrm{F} . & 7,000 & 1.6 \times 10^{5} \\ 180^{\circ} \mathrm{F} . & 3.000 & 6 \times 10^{\circ}\end{array}$

C. $75^{\circ}$ F. Bulk Modulus, Shear Modulus, and Poisson's Ratio - knit supported

17 ply laminate -0.1 inches thick (ASTM D-3039) cure -60 minutes at $250^{\circ} \mathrm{F}$.

Modulus of Elasticity $\quad 161 \times 10^{3} \mathrm{psi}$

Poisson's Ratio $\quad 0.34$

Shear Modulus $\quad 60 \times 10^{3} \mathrm{psi}$

D. Self-extinguishing Characteristics: knit supported.

Method: FAR 25.853 - Sample: $1 / 4^{\prime \prime} \times 1 / 2 " \times 4^{\prime \prime}$

Cure: 60 minutes at $250^{\circ} \mathrm{F}$.

\begin{tabular}{lll}
$\begin{array}{l}\text { Sample } \\
\text { Orientation }\end{array}$ & $\begin{array}{l}\text { Flame } \\
\text { Exposure } \\
\text { Time } \\
\text { (Seconds) }\end{array}$ & $\begin{array}{l}\text { Self- } \\
\text { Extinguishing } \\
\text { Time } \\
\text { (Seconds) }\end{array}$ \\
\hline $\begin{array}{l}\text { 4" length horizontal } \\
\text { and 1/2" dimension vertical }\end{array}$ & 15 & 0.5 \\
Same as (1) & 60 & 3.7 \\
4" length vertical & 15 & 6.3 \\
Same as (3) & 60 & 70
\end{tabular}




\section{Product Performance (cont):}

II Typical Cured Bond Properties

A. $75^{\circ}$ F. Fracture Toughness - (AC \& S method C-295)

Cure Cycle: $235^{\circ} \mathrm{F} .-90$ minutes $-35 \mathrm{psi}-5^{\circ} \mathrm{F} / \mathrm{min}$.

Primer: EC-3960

Metal: 2024 T-3 Bare 1/2" thick aluminum Phosphoric Acid Anodize

\begin{tabular}{|c|c|c|c|c|}
\hline & & AF-163-2K .06 & AF-163-2OST.03 & AF-163-20ST.06 \\
\hline & IN LBS & & & \\
\hline Gic & $\frac{1 N^{2}}{10}$ & 25 & 22 & 21 \\
\hline$G_{I A}$ & IN LBS & 15 & 13 & 13 \\
\hline
\end{tabular}

B. Thick Adherend Shear Properties - (AC \& S method C-288)

Cure Cycle: $270^{\circ} \mathrm{F}$. -60 minutes $-40 \mathrm{psi}-1^{\circ} \mathrm{F} . \mathrm{min}$.

Adherends: 2024 T-3 Bare 0.25 inch thick aluminum - FPL etched

Primer: EC.3924B

\begin{tabular}{clllll}
$\begin{array}{l}\text { Test } \\
\text { Temp. }\end{array}$ & $\begin{array}{l}\text { Ultimate } \\
\text { Shear-PSI }\end{array}$ & $\begin{array}{l}\text { Ultimate } \\
\text { Elong. In. }\end{array}$ & $\begin{array}{l}\text { Yield } \\
\text { Stress - PSI }\end{array}$ & $\begin{array}{l}\text { Yield } \\
\text { Elong. In. }\end{array}$ & $\begin{array}{l}\text { Shear } \\
\text { Modulus - PSI }\end{array}$ \\
\hline $75^{\circ} \mathrm{F}$. & 6950 & .0052 & 5255 & .00074 & 63,685 \\
$180^{\circ} \mathrm{F}$. & 5780 & .0114 & 3075 & .00079 & 26,495
\end{tabular}

C. Metal to Metal Wide Area Blister Detection Shear Strength - PSI (AC \& S method C-2232)

Cure: $235^{\circ} \mathrm{F} .-90$ minutes $-35 \mathrm{psi}-5^{\circ} \mathrm{F} . / \mathrm{min}$.

Primer: EC-3960 Metal: 2024 T-3 Bare .063" thick - FPL etched

\begin{tabular}{|c|c|c|c|c|c|}
\hline & \multicolumn{2}{|c|}{ AF-163-2OST } & \multirow{2}{*}{$\frac{\text { AF-163-2M }}{W t .06}$} & \multicolumn{2}{|c|}{ AF-163-2K } \\
\hline & Wt. .03 & Wt. .06 & & Wt. .06 & Wt. .085 \\
\hline$-67^{\circ} \mathrm{F}$ & 5500 & 4800 & 5200 & 5400 & 5100 \\
\hline $75^{\circ} \mathrm{F}$. & 5400 & 5400 & 5100 & 5100 & 5000 \\
\hline $180^{\circ} \mathrm{F}$ & 3700 & 3800 & 3700 & 3500 & 3400 \\
\hline $250^{\circ} \mathrm{F}$. & 2400 & 2400 & 2400 & 2400 & 2200 \\
\hline
\end{tabular}

D. Metal to Metal Overlap Shear Strength - PSI (AC \& S method C-244)

Cure Cycle: $250^{\circ} \mathrm{F},-60$ minutes $-20 \mathrm{psi}-1^{\circ} \mathrm{F}$./minute

Primer: EC-3917 Metal: 2024 T.3 ALCLAD .063" thick - unsealed Chromic Acid Anodized

\begin{tabular}{|c|c|c|c|c|}
\hline & \multirow{2}{*}{$\frac{\text { AF-163-20ST }}{W t . .03}$} & \multirow{2}{*}{$\frac{\text { AF-163-2M }}{W t .06}$} & \multicolumn{2}{|c|}{ AF-163-2K: } \\
\hline & & & Wt. .06 & Wt. .085 \\
\hline$-67^{\circ} \mathrm{F}$. & 5400 & 6400 & 6200 & 5100 \\
\hline $75^{\circ} \mathrm{F}$. & 5200 & 5700 & 5800 & 5400 \\
\hline $180^{\circ} \mathrm{F}$. & 3200 & 3600 & 3800 & 3800 \\
\hline
\end{tabular}

4 


\section{Product Performance (cont):}

E. Metal to Metal Blister Detection Shear (AC \& S method C-265)

Cure Cycle: $270^{\circ} \mathrm{F} .-60$ minutes $-40 \mathrm{psi}-1^{\circ} \mathrm{F}$./minute rise rate

Primer: EC-3924B

Metal: 2024 T-3 Bare 0.063 inches thick - FPL etched

Test Temperature

AF-163-2K Wt. .06

AF-163-2M Wt. .06

$-67^{\circ} \mathrm{F}$ :

6900

7000 psi

$75^{\circ} \mathrm{F}$.

5100

5000 psi

$180^{\circ} \mathrm{F}$.

3600

$3600 \mathrm{psi}$

Used $1 / 4$ inch overlap instead of $1 / 2$ inch overlap used for $75^{\circ} \mathrm{F}$. and $180^{\circ} \mathrm{F}$. testing.

F. Metal to Metal T-Peel Strength - PIW (AC \& S method C-252)

Cure Cycle: $250^{\circ} \mathrm{F} .60$ minutes $-20 \mathrm{psig}-1^{\circ} \mathrm{F}$. minute rise rate

Primer: EC-3917 Metal: 2024 T-3 clad .020" thick aluminum unsealed Chromic Acid Anodized

Peel Rate: 20 inches/minute

\begin{tabular}{|c|c|c|c|c|}
\hline \multirow[b]{2}{*}{ Test Temperature } & \multirow{2}{*}{$\frac{\text { AF-163-2OST }}{\text { Wt. .03 }}$} & \multirow{2}{*}{$\frac{\text { AF. } 163-2 M}{\text { Wt. } .06}$} & \multicolumn{2}{|c|}{ AF-163-2K } \\
\hline & & & Wt. .06 & Wt. .085 \\
\hline$-67^{\circ} \mathrm{F}$ & 25 & 25 & 33 & 29 \\
\hline $75^{\circ} \mathrm{F}$ & 29 & 44 & 45 & 41 \\
\hline $180^{\circ} \mathrm{F}$. & 24 & 40 & 38 & 35 \\
\hline $250^{\circ} \mathrm{F}$. & 20 & 30 & 28 & 20 \\
\hline
\end{tabular}

G. Metal to Metal Floating Roller (Bell) Peel Strength - PIW (AC \& S method C-260)

1. Cure Cycle: $270^{\circ} \mathrm{F} .-60$ minutes $-50 \mathrm{psi}-1^{\mathrm{P}} \mathrm{F}$. minute rise rate

Primer: EC-3924B

Metal: 2024T-3 Bare FPL etched .025" to .063" aluminum

Peel Rate: 6 inchesiminute

\begin{tabular}{rll} 
Test Temperature & AF-163-2K .06 & AF-163-2M.06 \\
\hline$-67^{\circ} \mathrm{F}$. & 78 piw & 58 piw \\
$75^{\circ} \mathrm{F}$. & 78 piw & 79 piw \\
$180^{\circ} \mathrm{F}$. & 76 piw & 76 piw
\end{tabular}

2. Cure: $250^{\circ} \mathrm{F} .-60 \mathrm{~min} .-30 \mathrm{psig}-5^{\circ} \mathrm{F}$.minute rise rate

Primer: EC-39248

Metal: 7075 T6 CLAD Chromic Acid Anodize $.025^{\prime \prime}$ to $.063^{\prime \prime}$ Aluminum

Peel Rate: 6 inches/minute

\begin{tabular}{|c|c|c|c|}
\hline \multirow[b]{2}{*}{ Test Temperature } & \multicolumn{2}{|c|}{ AF-163-2M } & \multirow{2}{*}{$\frac{\text { AF-163-2K }}{W t .045}$} \\
\hline & Wt. .045 & Wt. .085 & \\
\hline$-67^{\circ} \mathrm{F}$ & 57 & 55 & - \\
\hline $75^{\circ} \mathrm{F}$. & 55 & 63 & 55 \\
\hline $160^{\circ} \mathrm{F}$. & 46 & 45 & - \\
\hline
\end{tabular}


H. Metal to Metal Climbing Drum Peel Strength-In. Lbs./In. - (AC \& S method C-2222)

Cure Cycle: $235^{\circ} \mathrm{F}$ - 90 minutes $-35 \mathrm{psig}-5^{\circ} \mathrm{F}$.minute rise rate

Primer: EC-3960 Metal: 2024 T-3 Clad aluminum 020 inch to 040 inch FPL etched

Peel Rate: 3 inches'minute (cross head travel)

Test Temperature: $75 \pm 5^{\circ} \mathrm{F}$.

Adhesive

Peel Strength-In. Lbs./In.

AF-163-2OST.03 70

AF-163-20ST.06 75

AF-163-2K.06 80

AF-163-2M.06 80

I. Metal to Honeycomb Climbing Drum Peel Strength - (AC \& S method C-245)

1. Cure Cycle: $250^{\circ} \mathrm{F} .60$ minutes $-20 \mathrm{psi}-1^{\circ} \mathrm{F} / \mathrm{min}$

Primer for Skins: EC-3917

Skins: 2024 T3 0.020 inches thick aluminum - Chromic Acid Anodized

Core: $1 / 4^{\prime \prime}$ cell $-1 / 2^{\prime \prime}$ thick -4 mil foil -5052 alloy - non perforated

Test Rate: 1.0 inches/minute (cross head)

Strength-In. Lbs./in.

\begin{tabular}{cll} 
Test Temperature & AF-163-2K & AF-163-2M \\
\hline$-67^{\circ} \mathrm{F}$. & Wt. .06 & Wt. .06 \\
$75^{\circ} \mathrm{F}$. & 20 & 17 \\
$180^{\circ} \mathrm{F}$. & 23 & 26 \\
$250^{\circ} \mathrm{F}$. & 18 & 19 \\
& 9 & 9
\end{tabular}

2. Cure Cycle: $250^{\circ} \mathrm{F} .-60$ minutes $-30 \mathrm{psi}-5^{\circ} \mathrm{F}$./minute

Primer: EC-39248

Skins and Core: as per (1) above

Test Rate: 1.0 Inches/minute (cross head)

\begin{tabular}{|c|c|c|c|}
\hline Test Temperature & $\begin{array}{l}\text { AF-163-2K } \\
\text { Wt. .045 }\end{array}$ & $\begin{array}{l}\text { Strength-In. Lbs./In. } \\
\text { AF-163-2M } \\
\text { Wt. .045 }\end{array}$ & $\begin{array}{l}\text { AF-163-2M } \\
\text { Wt. } 085\end{array}$ \\
\hline$-67^{\circ} F$ & - & 15 & 33 \\
\hline $75^{\circ} \mathrm{F}$ & 15 & 15 & 39 \\
\hline $160^{\circ} \mathrm{F}$ & - & 12 & 34 \\
\hline
\end{tabular}

3. Cure Cycle: $235^{\circ} \mathrm{F} .-90 \mathrm{~min} .-35 \mathrm{psi}-5^{\circ} \mathrm{F}$./minute

Primer: EC-3960

Skins: 2024 T-3 0.020 inch aluminum - FPL etched

Core: as per (1) above

Test Rate: 3 inches/minute (cross head)

Adhesive 75F. Peel Strength-In. Lbs./nn.

$\begin{array}{ll}\text { AF-163-2K .06 } & 22 \\ \text { AF-163-2K .085 } & 35 \\ \text { AF-163-2M .06 } & 24 \\ \text { AF-163-2M .085 } & 35 \\ \text { AF-163-2OST .06 } & 20\end{array}$




\section{Product Performance (cont):}

4. Cure Cycle: $270^{\circ} \mathrm{F} .-60 \mathrm{~min} .-50 \mathrm{psi}-1^{\circ} \mathrm{F} . \mathrm{min}$.

Primer: EC-3924B

Skins: as (3) above

Core: $3 / 16^{\prime \prime}$ cell $-1 / 2$ " thick -5052 alloy - non perforated

Test Rate: 1.0 inches/minute (cross head)

Strength-In. Lbs./In.

\begin{tabular}{cllll} 
& \multicolumn{2}{c}{ AF-163-2U } & & AF-163-2K \\
Test Temperature & Wt. .03 & Wt. .06 & & Wt. .06 \\
\hline$-67^{\circ} \mathrm{F}$. & - & - & 33 \\
$75^{\circ} \mathrm{F}$. & 15 & 36 & 31 \\
$180^{\circ} \mathrm{F}$. & - & - & & 24
\end{tabular}

J. Metal to Honeycomb Flatwise Tensile - (AC \& S method C-251)

1. Cure Cycle: $250^{\circ} \mathrm{F}$. -60 minutes $-20 \mathrm{psig}-1^{\circ} \mathrm{F} / \mathrm{min}$. rise rate Primer for Skins: EC-3917

Metal: Skins: 2024 T-3 aluminum - Chromic Acid Anodized

Core: $1 / 4^{\prime \prime}$ cell $-1 / 2$ " thick -4 mil foil -5052 alloy - non perforated

$$
\text { Strength - PSI }
$$

\begin{tabular}{ccc} 
& \multicolumn{2}{c}{ AF-163-2K } \\
\cline { 2 - 3 } Test Temperature & Wt. .06 & Wt. .085 \\
\hline$-67^{\circ} \mathrm{F}$. & 1700 & 1800 \\
$75^{\circ} \mathrm{F}$. & 1200 & 1400 \\
$180^{\circ} \mathrm{F}$. & 700 & 825 \\
$250^{\circ} \mathrm{F}$. & 260 & 290
\end{tabular}

2. Cure cycle: $250^{\circ} \mathrm{F}$. -60 minutes $-30 \mathrm{psig}-5^{\circ} \mathrm{F}$./minute rise rate

Primer for Skins: EC-3924B

Metal \& Core: same as (1) above

\begin{tabular}{cccc} 
& \multicolumn{3}{c}{$\begin{array}{c}\text { Strength - PSI } \\
\text { Af-163-2M }\end{array}$} \\
\cline { 2 - 4 } Test Temperature & Wt. .045 & Wt. .06 & Wt. .085 \\
\hline$-67^{\circ} \mathrm{F}$. & 1400 & - & 1900 \\
$75^{\circ} \mathrm{F}$. & 935 & 1150 & 1500 \\
$160^{\circ} \mathrm{F}$. & 625 & 750 & 990
\end{tabular}

3. Cure Cycle: $235^{\circ} \mathrm{F} .-90$ minutes $-35 \mathrm{psi}-5^{\circ} \mathrm{F} / \mathrm{min}$. rise rate

Primer for Skins: EC-3960

Metal: Skins; 2024 T-3 aluminum - FPL etched

Core: same as (1) above

\begin{tabular}{|c|c|c|c|c|c|}
\hline \multirow[b]{2}{*}{ Test Temperature } & \multicolumn{2}{|c|}{$A F-163-2 U$} & \multicolumn{2}{|c|}{$\begin{array}{c}\text { Strength - PSI } \\
\text { AF-163-2K }\end{array}$} & \multirow{2}{*}{$\frac{\text { AF-163-2OST }}{\text { Wt. } .06}$} \\
\hline & $\overline{\text { Wi. } .03}$ & Wt. 06 & Wt. .06 & Wt. .085 & \\
\hline $75^{\circ} \mathrm{F}$ & 800 & 1200 & 1150 & 1350 & 1150 \\
\hline $180^{\circ} \mathrm{F}$. & 500 & 700 & 650 & 800 & 625 \\
\hline $250^{\circ} \mathrm{F}$ & - & - & 250 & 275 & 250 \\
\hline
\end{tabular}


K. Metal to Honeycomb Beam Flexure Strength - LBS. - (AC \& S method C-250)

Cure Cycle: $250^{\circ} \mathrm{F} .-60$ minules $-30 \mathrm{psi}-5^{\circ} \mathrm{F}$./minute rise rate

Primer: EC-3924B

Metal: 2024 T-3 Bare 0.063 inch thick aluminum - Chromic Acid Anodized

Core: $1 / 4$ inch cell $-1 / 2$ inch thick -5052 Alloy -4 mil foil - non perforated

\begin{tabular}{clcl} 
& \multicolumn{3}{c}{ AF-163-2M } \\
\cline { 2 - 4 } Test Temperature & Wt. 045 & Wt. .06 & Wt. .085 \\
\hline$-67^{\circ} \mathrm{F}$. & 3050 & 3150 & 3200 \\
$75^{\circ} \mathrm{F}$. & 2850 & 3160 & 3200 \\
$160^{\circ} \mathrm{F}$. & 2100 & 2600 & 2860
\end{tabular}

L. Typical Metal to Metal Fatigue Resistance:

1. Wide Area Blister Shear Type Specimens - C-2232 Type

Cure Cycle: $235^{\circ} \mathrm{F}$ - 90 minutes $-35 \mathrm{psi}-5^{\circ} \mathrm{F}$./minute rise rate

Primer: EC-3960 Metal: 2024 T-3 Bare .063 inch thick aluminum - FPL etched

Max. Stress: 1500 psi Stress Ratio: 0.1 Rate: 1800 cycles/minute

Test Temperature: $75 \pm 5^{\circ} \mathrm{F}$.

Results: Under these conditions AF-163-2 films have yielded greater than $10^{\prime}$ cycles without adhesive failure

2. Double Lap Strap 6, 4 Titanium Specimens

Cure Cycle: $250^{\circ} \mathrm{F},-60$ minutes $-20 \mathrm{psig}-1^{\circ} \mathrm{F}$.minute rise rate

Primer: EC-3917 Adhesive: AF-163-2K Wt. 06

Metal: 6, 4 Titanium alloy - phosphate fluoride etched

Center Adherends 1 inch $\times 4 \%$ inches $\times 0.125$ inches

Straps 1 inch $\times 1 \%$ inches $\times .063$ inches

Stress Ratio $=0.1$ Rate $=1800$ cycles $/$ minute $\quad$ Test temp. $=75^{\circ} \mathrm{F}, \pm 5^{\circ} \mathrm{F}$.

Shear Area -1.5 square inches

Max. Stress (PSI)

Avg. Lite (Cycles)

4500

$1.58 \times 10^{4}$

4000

$5.28 \times 10^{4}$

3500

$4.75 \times 10^{5}$

3000

$2.67 \times 10^{6}$

2200

NF $-1.03 \times 10^{\prime}$

$\mathrm{NF}=$ No failure, test discontinued.

M. Typical Creep Resistance

1. Metal to Metal Wide Area Shear Specimens - C-2232 Type

Cure Cycle: $235^{\circ} \mathrm{F}$. -90 minutes $-35 \mathrm{psig}-5^{\circ} \mathrm{F} /$ minute rise rate

Primer: EC-3960

Metal: 2024 T-3 Bare .063" thick aluminum - FPL etched

\begin{tabular}{rll} 
Adhesive & \multicolumn{2}{c}{$\begin{array}{c}\text { Creep after } 192 \text { hours in inches } \\
\mathbf{1 8 0} \text { F. }-800 \text { psi }\end{array}$} \\
\hline AF-163-2K .06 & Less than 0.0003 & $\leqslant .0012$ \\
.085 & Less than 0.0003 & $\leqslant .0015$ \\
AF-163-2OST .03 & Less than 0.0003 & Less than 0.0003 \\
.06 & Less than 0.0003 & Less than 0.0003
\end{tabular}

8 
2. Metal to Metal Overlap Shear Specimens - C-245 Type

Cure Cycle: $250^{\circ} \mathrm{F} .-60$ minutes $-30 \mathrm{psi}-5^{\circ} \mathrm{F} . / \mathrm{min}$ rise rate

Primer: EC-3924B

Metal: 7075 T.6 Clad .063" thick aluminum - Chromic Acid Anodized

\begin{tabular}{lll} 
Adhesive & \multicolumn{2}{c}{ Creep after 192 hours in inches } \\
AF-163-2M .085 & Less than 0.0003 & Less than 0.0003
\end{tabular}

3. Metal to Honeycomb Creep Deflection in Flexure - (Mil-A-25463 method)

Cure Cycle: $250^{\circ} \mathrm{F},-60$ minutes $-30 \mathrm{psig}-5^{\circ} \mathrm{F}$./minute rise rate

Primer: EC-3924B

Metal: 2024 T-3 Bare 0.063 inch thick aluminum - Chromic Acid Anodized

Core: $1 / 4$ inch cell $-1 / 2$ inch thick -5052 Alloy -4 mil foil - non perforated

Deflection after 192 hours in inches

\begin{tabular}{|c|c|c|c|c|c|c|c|}
\hline \multirow[b]{2}{*}{ Adhesive } & \multirow[b]{2}{*}{ (Stress) } & \multicolumn{2}{|c|}{$75^{\circ} \mathrm{F}$. Test } & \multicolumn{2}{|c|}{$160^{\circ} \mathrm{F}$. Test } & \multicolumn{2}{|c|}{$180^{\circ} \mathrm{F}$. Test } \\
\hline & & 970 Lbs. & 1500 Lbs. & 970 Lbs. & 1500 Lbs. & 970 Lbs. & 1500 Lbs. \\
\hline \multicolumn{8}{|l|}{ AF-163-2M } \\
\hline Wt. .045 & & .0005 & - & .003 & - & .005 & - \\
\hline Wt. .085 & & - & 0.0011 & - & .006 & - & .017 \\
\hline
\end{tabular}

N. Typical Bond Strengths on Other Substrates

Adhesive: AF-163-2M Wt. 045

Primer: EC-39248

Cure Cycle: $250^{\circ} \mathrm{F} .-60$ minutes $-30 \mathrm{psig}-5^{\circ} \mathrm{F}$.minute

\begin{tabular}{|c|c|c|}
\hline Substrate & 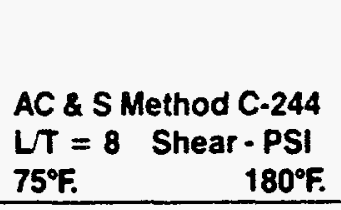 & $\begin{array}{l}\text { AC \& S Method C-260 } \\
6 \text { inches per minute } \\
\text { Floating Roller } \\
\text { Bell Peel - PIW } \\
75^{\circ} \text { F. } \\
\end{array}$ \\
\hline $\begin{array}{l}7075 \text { T6 Clad } \\
\text { FPL-Elch }\end{array}$ & $\begin{array}{l}.063^{\prime \prime} \text { Thick Metal } \\
6050 \quad 3500\end{array}$ & $\begin{array}{l}.025^{\prime \prime} \text { Thick Metal Peel Skin } \\
65\end{array}$ \\
\hline $\begin{array}{l}\text { 6, } 4 \text { Titanium } \\
\text { Phosphate Fluoride Elch }\end{array}$ & $\begin{array}{l}0.063^{\prime \prime} \text { Thick Metal } \\
6825 \quad 3650\end{array}$ & $\begin{array}{l}.014 " \text { Thick Metal Peel Skin } \\
45\end{array}$ \\
\hline $\begin{array}{l}301 \text { Stainless Steel } \\
\mathrm{HNO}_{3}-\mathrm{HF} \text { Etch }\end{array}$ & $\begin{array}{l}0.060^{\prime \prime} \text { Thick Metal } \\
6260 \quad 3750\end{array}$ & $\begin{array}{l}0.020 " \text { Thick Metal Peel Skin } \\
60\end{array}$ \\
\hline $\begin{array}{l}\text { Epoxy FRP } \\
\text { ("Scotchply" Brand Type 116) } \\
\text { Abrade \& degrease : } \\
\text { unprimed }\end{array}$ & $\begin{array}{l}0.150 \text { Thick Skin } \\
=4300 \quad=2300\end{array}$ & - \\
\hline
\end{tabular}

III Typical Performance after Environmental Exposure

A. Metal to Metal Overlap Shear Strength - PSI - (AC \& S method C-244)

Cure Cycle: $250^{\circ} \mathrm{F} .-60$ minutes $-30 \mathrm{psig}-5^{\circ} \mathrm{F}$. $/$ minute rise rate

Primer: EC-3924B

Metal: 7075 T-6 Clad 0.063" thick - Chromic Acid Anodized 


\section{Product Performance (cont):}

Adhesive: AF-163-2M Wt. 085

Specimens: Precut to 1 inch width prior to exposure

Environmental Exposure

75․ Lap Shear Strength (PSI)

1. Control (No Exposure) 6345

2. 7 day immersion in JP.4

6570

3. 7 day immersion in Mil-F-5566

6365

4. 7 day immersion in Mil-H-5606

6465

5. 7 day immersion in Type III Hydrocarbon

6510

6. 30 day water immersion

5860

7. 30 day $5 \%$ Salt Spray Exposure

8. "Cyclic Humidity Exposure a) 15 Cycles

6245

b) 30 Cycles

5510

c) 45 Cycles

5655

-Each Cycle: 16 hours @ 125 $5^{\circ}$. at $95-100 \%$ RH followed by 8 hours at $-67^{\circ} \mathrm{F}$.

B. Metal to Metal Blister Detection Shear - (AC \& S method C-265)

Cure Cycle: $270^{\circ} \mathrm{F}-40 \mathrm{psi}-60$ minutes $-1^{\circ} \mathrm{F}$./minute rise rate

Primer: EC-3924B

Metal: 2024 T-3 Base $.063^{\prime \prime}$ thick aluminum - FPL etch

Adhesive: AF-163-2K Wt. 06

Specimens: Precut to 1.0 inch width and notched prior 10 exposure

Environmental Exposure $7^{\circ} \mathrm{F}$. Shear Strength (PSI)

1. Control (No Exposure) 5095

2. 7 day immersion in JP-4 5065

3. 7 day immersion in Mil-4-5606 5050

4. 7 day immersion in Mil-L-7808

5005

5. 30 day Exp. $120^{\circ}$ F. -95 to $100 \%$ RH

4980

6. 30 day Exp. to $5 \%$ Salt Spray

5030

C. Metal to Metal Floating Roller (Bell) Peel - (AC \& S method C-260)

Cure Cycle: (same as above)

Primer: EC-3924B

Metal: 2024 T-3 Bare .025" Thick to .063" thick aluminum - FPL etched

Adhesive: AF-163-2K WI. 06

Specimens: Precut to 1 inch wide belore exposure

Peel Rate: 6 inches/minute

Environmental Exposure

75․ Peel Strength (PIW)

1. Contral (No Exposure) 82

2. 7 day immersion in JP-4

83

3. 7 day immersion in Mil-H-5606

85

4. 7 day immersion in Mil-L. 7808

84

5. 30 day Exposure $120^{\circ} \mathrm{F}$, and 95 to $100 \% \mathrm{RH}$

80

6. 30 day $5 \%$ Salt Spray Exposure

82

10 
D. Metal to Metal Wide Area Blister Detection Shear - PSI - (AC \& S method C-2232)

Cure Cycle: $235^{\circ} \mathrm{F} .-90$ minutes $-35 \mathrm{psi}-5^{\circ} \mathrm{F}$. minute rise rate

Primer: EC-3960

Metal: 2024 T-3 Bare 0.063 inches thick - FPL etched

Specimens: Precut to 1.0 inch width and notched prior to exposure

\begin{tabular}{|c|c|c|c|c|}
\hline \multirow{3}{*}{$\begin{array}{l}\text { Environmental } \\
\text { Exposure }\end{array}$} & \multicolumn{4}{|c|}{ 75'F. Shear Strength - PSI } \\
\hline & \multicolumn{2}{|c|}{ AF-163-20ST } & \multicolumn{2}{|c|}{ AF-163-2K } \\
\hline & Wt. .03 & Wt. .06 & Wt. .06 & Wt. .085 \\
\hline 1. Control (No Exposure) & 5405 & 5280 & 5105 & 5115 \\
\hline 2. 7 day JP-4 minimum $\left(75^{\circ} \mathrm{F}\right.$.) & 5345 & 5255 & 5225 & 5079 \\
\hline $\begin{array}{l}\text { 3. } 7 \text { day Type III Hydrocarbon immersion } \\
\left(75^{\circ} \mathrm{F} .\right)\end{array}$ & 5340 & 5315 & 5255 & 5160 \\
\hline 4. 7 day Skydrol $500 \mathrm{~B}$ immersion ( $150^{\circ} \mathrm{F}$.) & 5400 & 5470 & 5214 & 5135 \\
\hline 5. 30 day $5 \%$ Salt Spray & 5330 & 5105 & 4865 & 4635 \\
\hline 6. 30 day $120^{\circ} \mathrm{F} .-95-100 \% \mathrm{RH}$ & 5360 & 5200 & 4940 & 4735 \\
\hline
\end{tabular}

E. Metal to Metal Giscc - Crack Extension at $140^{\circ} \mathrm{F}$. and $95-100 \%$ RH - (AC \& S method C-295)

Cure Cycle: $235^{\circ} \mathrm{F} .-90 \mathrm{~min} .-35 \mathrm{psig}-5^{\circ} \mathrm{F} / \mathrm{min}$. rise rate

Primer: EC-3960

Metal: 2024 T-3 Bare 0.5 inch thick aluminum - phosphoric acid anodized

Specimen: DCB specimen precut to 1.0 inch width prior to exposure

$$
\text { Giscc - In. Lbs./In.' }
$$

\begin{tabular}{lllll} 
Exposure & \multicolumn{3}{c}{ AF-163-20ST } & \multicolumn{3}{c}{ AF-163-2K } \\
\hline Time (hours) & Wt. 03 & Wt. 06 & Wt. .06 & Wt. 085 \\
2500 hours & 6.4 & 7.5 & 7.2 & 8.5
\end{tabular}

F. Metal to Honeycomb Beam Flexure Strength (Lbs) - (AC \& S method C-250)

Cure Cycle: $250^{\circ} \mathrm{F}$ - -60 minutes $-30 \mathrm{psi}-5^{\circ} \mathrm{F} / \mathrm{min}$

Primer for Skins: EC-3924B

Metal Skins: 2024 T-3 Bare 0.063 inches thick aluminum - Chromic Acid Anodized

Core: $1 / 4$ inch cell $-1 / 2$ inch thick -4 mil foil -5052 Alloy - non perforated

Adhesive: AF-163-2M Wt. 045

Environmental Exposure

$75^{\circ}$ F. Flexural Strength - Lbs.

1. Control (No Exposure)

2850

2. 30 day immersion in Type III Hydrocarbon 2800

3. 30 day $5 \%$ Salt Spray 2800

4. 'Cyclic Exposure - 45 Cycles 2900

G. Metal to Honeycomb Flatwise Tensile Strength - PSI - (AC \& S method C-251) conditions as per (F) above Environmental Exposure $75^{\circ}$ F. Flatwise Tensile Strength - PSI

1. Control (No Exposure) 935

2. "Cyclic Exposure: 15 Cycles 865

45 Cycles 870

"Each Cycle: 16 hours at $125^{\circ} \mathrm{F}$. and $95-100 \% \mathrm{RH}$ followed by 8 hours at $-67^{\circ} \mathrm{F}$. 


\section{Product Performance (cont):}

IV Typical Performance after Open Time at $90^{\circ} \mathrm{F}$. and $75 \% \mathrm{RH}$

Cure Cycle: $250^{\circ} \mathrm{F} .-60$ minutes $-30 \mathrm{psig}-5^{\circ} \mathrm{F}$. $\mathrm{min}$. rise rate

Primer: EC-3924B Metal Skin Prep: Chromic Acid Anodize

Core: $1 / 4^{\prime \prime}$ cell $-1 / 2^{\prime \prime}$ thick - 4 mil foil - 5052 Alloy - non-perforated

Exposure Method: Adhesive applied to Primed Skin with liners removed and exposed open face

A. $75^{\circ}$ F. Overlap Shear on 7075 T-6 Clad .063 inch thick aluminum - (AC \& S method C-244)

\begin{tabular}{ll} 
Exposure Time & AF-163-2M Wt. 045 \\
\hline 0 & $6300 \mathrm{psi}$ \\
7 days & $6400 \mathrm{psi}$ \\
15 days & $6500 \mathrm{psi}$
\end{tabular}

B. Floating Roller (Bell) Peel on 7075 T-6 Clad .025" to .063" aluminum - (AC \& S method C-260)

AF-163-2M Wt. 045

\begin{tabular}{llll}
\cline { 2 - 4 } Exposure Time & $-67^{\circ} \mathrm{F}$. Test & $75^{\circ} \mathrm{F}$. Test & $160^{\circ} \mathrm{F}$. Test \\
\hline 0 & $57 \mathrm{piw}$ & $55 \mathrm{piw}$ & $46 \mathrm{piw}$ \\
7 days & $55 \mathrm{piw}$ & $61 \mathrm{piw}$ & $50 \mathrm{piw}$ \\
15 days & $59 \mathrm{piw}$ & $55 \mathrm{piw}$ & $44 \mathrm{piw}$
\end{tabular}

C. $75^{\circ}$ F. Honeycomb Peel 2024 T-3 Bare .020 Aluminum Skins - (AC \& S method C-245)

\begin{tabular}{|c|c|c|}
\hline \multirow[b]{2}{*}{ Exposure Time } & \multicolumn{2}{|c|}{ AF-163-2M } \\
\hline & Wt. 045 & Wt. 085 \\
\hline 0 & 15 ln. Lbs.//n. & 39 ln. Lbs.'In. \\
\hline 7 days & 15 ln. Lbs.//n. & 31 ln. Lbs./In. \\
\hline 15 days & $11 \mathrm{ln}$. Lbs./in. & 26 In. Lbs.. In. \\
\hline
\end{tabular}

D. $75^{\circ}$ F. Honeycomb Flatwise Tensile 2024 T-3 Bare Aluminum Skins - (AC \& S method C-251)

\begin{tabular}{lcc} 
& \multicolumn{2}{c}{ Af-163-2M } \\
\cline { 2 - 3 } Exposure Time & Wt. .045 & Wt. .085 \\
\hline 0 & $935 \mathrm{psi}$ & $1500 \mathrm{psi}$ \\
7 days & $1050 \mathrm{psi}$ & $1600 \mathrm{psi}$ \\
15 days & $1000 \mathrm{psi}$ & $1570 \mathrm{psi}$
\end{tabular}

$\checkmark$ Typical Metal to Metal 200 ${ }^{\circ}$. Cure Performance:

Cure Cycle: $200^{\circ} \mathrm{F}, \pm 5^{\circ} \mathrm{F} .-50 \mathrm{psi}-1^{\circ} \mathrm{F} / \mathrm{min}$ rise rate

Primer: EC-3924B

AF-163-2K Wt. .06

\begin{tabular}{llll} 
Cure Time & \multicolumn{2}{c}{$\begin{array}{l}\text { Blister Detection Shear } \\
\text { (AC \& S method C-265) }\end{array}$} & $\begin{array}{l}\text { Fioating Roller (Bell) Peel } \\
\text { (AC \& S method C-260) }\end{array}$ \\
\hline & $75^{\circ} \mathrm{F}$. Test & $180^{\circ} \mathrm{F}$. Test & $75^{\circ} \mathrm{F}$. Test \\
A. 2 hours & $4120 \mathrm{psi}$ & $1750 \mathrm{psi}$ & $68 \mathrm{piw}$ \\
B. 4 hours & $4580 \mathrm{psi}$ & $2880 \mathrm{psi}$ & $76 \mathrm{piw}$ \\
C. 6 hours & $4700 \mathrm{psi}$ & $3280 \mathrm{psi}$ & $77 \mathrm{piw}$
\end{tabular}

12 


\section{Product Performance (cont):}

\section{Typical Vacuum Cure Performance}

Cure: $250^{\circ} \mathrm{F} .-60$ minutes $-5^{\circ} \mathrm{F} . / \mathrm{min}$ rise rate

Primer: EC-3960

Overlap Shear: (AC \& S method C-244) - 2024 T-3 .063" thick aluminum

Honeycomb Peel: (AC \& S method C-245) - 1/4" cell Core - 2024 T-3 .020" thick aluminum skins

Peel Rate: 3 inchesiminute (cross head travel)

\begin{tabular}{|c|c|c|c|c|c|}
\hline \multirow[b]{2}{*}{$\begin{array}{l}\text { Pressure } \\
\text { (Vacuum) }\end{array}$} & \multicolumn{2}{|c|}{ AF-163-2K.06 } & \multicolumn{2}{|c|}{ AF-163-2M .06 } & \multirow{2}{*}{$\begin{array}{l}\text { AF-163-2OST.03 } \\
\text { Overlap } \\
\text { Shear } \\
\text { of. } \\
\text { PSI }\end{array}$} \\
\hline & $\begin{array}{l}\text { Overlap } \\
\text { Shear } \\
75^{\circ} \mathrm{F} \text {. } \\
\text { PSI }\end{array}$ & $\begin{array}{l}\text { Honeycomb } \\
\text { Peel } \\
75^{\circ} \text { F. } \\
\text { In Lbs/3 in. }\end{array}$ & $\begin{array}{l}\text { Overlap } \\
\text { Shear } \\
75^{\circ} \mathrm{F} \text {. } \\
\text { PSI }\end{array}$ & $\begin{array}{l}\text { Honeycomb } \\
\text { Peel } \\
75^{\circ} \mathrm{F} \text {. } \\
\text { in Lbs } / 3 \text { In. }\end{array}$ & \\
\hline A. 25 psig positive pressure & 5700 & 77 & 6200 & 74 & 5600 \\
\hline B. 9.11 inches $\mathrm{Hg}$ & 5700 & 65 & 6000 & 75 & 5200 \\
\hline C. $16-18$ Inches $\mathrm{Hg}$ & 3800 & 54 & 6000 & 67 & 5500 \\
\hline D. $24-26$ Inches $\mathrm{Hg}$ & 3300 & 45 & 4800 & 59 & 5200 \\
\hline
\end{tabular}

VII Effect of rise rate on Typical Metal to Metal Properties

Primer: EC-3917 Metal Prep: Chromic Acid Anodize

Metal: (AC \& S method C-252) T-Peel 2024 T-3 Clad 0.020 inch aluminum

(AC \& S method C-244) OL Shear $2024 \mathrm{~T} .3 \mathrm{Clad} 0.063$ inch aluminum

T-Peel Rate: 20 inches/minute

Adhesive: AF-163-2K Wt. 06

\begin{tabular}{llll} 
Cure Temp. & $250^{\circ} \mathrm{F}$. & $250^{\circ} \mathrm{F}$. & $250^{\circ} \mathrm{F}$. \\
Cure Time & $60 \mathrm{~min}$. & $60 \mathrm{~min}$. & $60 \mathrm{~min}$. \\
Cure Pressure & $20 \mathrm{psig}$ & $20 \mathrm{psig}$ & $50 \mathrm{psig}$ \\
Rise Rate & $1^{\circ} \mathrm{F} . \mathrm{min}$. & $8^{\circ} \mathrm{F} . \mathrm{min}$. & $20^{\circ} \mathrm{F} . / \mathrm{min}$. \\
\hline $75^{\circ} \mathrm{F}$. Overlap Shear & $5760 \mathrm{psi}$ & $5840 \mathrm{psi}$ & $5640 \mathrm{psi}$ \\
$75^{\circ} \mathrm{F}$. T-Peel & $45 \mathrm{piw}$ & $46 \mathrm{piw}$ & $45 \mathrm{piw}$
\end{tabular}




\section{Product Application:}

Note: While this information is provided as a general application guideline based upon typical conditions, it is recognized that no two applications are identical due to differing assemblies, methods of heat and pressure application, production equipment and other limitations. It is therefore suggested that experiments be run, within the actual constraints imposed, to determine optimum conditions for your specific application and to determine suitability of product for particular intended use.

\section{Surface Preparation}

A thoroughly cleaned, dry, grease-free surface is essential for maximum performance. Cleaning methods which will produce a break free water film on metal surfaces are generally satisfactory.

A. Aluminum: Phosphoric acid anodize (AC \& S method C-2780), Chromic acid anodize with or without a chromate seal (AC \& S methods C-2801 or C-2782) are preferred for maximum joint durability in moist environments. Optimized FPL Etch has also demonstrated improved durability performance.

Optimized FPL Etch - 3M Company (AC \& S method C-2803)

1. Vapor degrease - perchloroethylene condensing vapors for 5-10 minutes

2. Alkaline degrease - Oakite 164 solution $9-11 \mathrm{oz}$. gallon of water at $190^{\circ} \mathrm{F} . \pm 10^{\circ} \mathrm{F}$. for 10 to 20 minutes. Rinse immediately in large quantities of cold running water (AC \& S method C-2802)

3. Acid Etch - Immerse panels in the following solution for 10 minutes at $150 \pm 5^{\circ} \mathrm{F}$.:

Sodium dichromate $\left(\mathrm{Na}_{2} \mathrm{Cr}_{2} \mathrm{O}, 2 \mathrm{H}_{2} \mathrm{O}\right)$

Sulfuric Acid $66^{3} \mathrm{Be}$

2024 T-3 aluminum (dissolved)

Tap Water

38.5-41.5 oz. gailon

$0.2 \mathrm{oz} / \mathrm{gal}$. minimum

Balance

4. Rinse immediately in large quantities of clear running tap water.

5. Dry - Air dry approximately 15 minutes followed by a force dry at $150^{\circ} \mathrm{F} . \pm 10^{\circ} \mathrm{F}$. for 10 minutes

6. Current theory suggests that both surface structure and chemistry play a significant role in determining the strength and permanence of bonded structure. It is therefore advisable to bond or prime freshly cleaned surfaces as early as possible after preparing to avoid contamination and/or mechanical damage.

\section{B. Aluminum Honeycomb Core}

1. Vapor degrease in condensing vapors of perchloroethylene or soak in clean aliphatic naphtha (conforming to TT$\mathrm{N}-95 \mathrm{~A}$ ) for five minutes at room temperature. Dry 10 minutes at $150^{\circ} \mathrm{F} . \pm 5^{\circ} \mathrm{F}$.

2. Optional - Immerse in etching solution above for 2 minutes at $150^{\circ} \mathrm{F} . \pm 5^{\circ} \mathrm{F}$. Rinse, air dry and force dry in a similar manner to skins. 


\section{Product Application:(cont.)}

C. Titanium CP or $6 \mathrm{Al} 4 \mathrm{~V}$ Both "Turco 5578 and improved phosphate fluoride processing have been used successfully with AF-163-2 Systems.

"Turco 5578 process

1. Vapor hone 140 grit in water - rinse thoroughly with clear running tap water.

2. Degrease - solvent or alkaline process.

3. Immerse for 15 minutes at $185 \pm 5^{\circ} \mathrm{F}$. in the following bath:

"Turco 5578 - 420 grams

Distilled water - Balance to make 1 liter

4. Immerse for 1 minute in $170^{\circ} \mathrm{F} . \pm 5^{\circ} \mathrm{F}$. distilled water.

5. Spray rinse for 5 minutes in hot tap water $\sim 130^{\circ} \mathrm{F}$.

6. Air dry for 10 to 20 minutes.

7. Force dry for 15 minutes at $150^{\circ} \mathrm{F}$.

8. It is advisable to bond or prime freshly cleaned surfaces within four hours.

-Turco Products division of Purex.

D. Stainless Steel - 301 Type

1. Vapor hone 140 grit in water.

2. Rinse thoroughly in clear running tap water.

3. Alkaline degrease - see A2 procedure above.

4. Rinse thoroughly in clear running tap water.

5. Immerse for 10 minutes at $75^{\circ} F . \pm 5^{\circ} F$. in the following bath:

Nitric Acid $42^{\circ}$ Be

Hydrofluoric Acid $70 \%$

Distilled Water

30-50 0z./gallon

3.5 02./gallon

Balance

6. Rinse thoroughly in clear running tap water.

7. Air dry for 10-20 minutes.

8. Force dry for 15 minutes at $150^{\circ} \mathrm{F}$.

9. Bond or prime within four hours after preparing.

E. Cured fiberglass or carbon fiber reinforced epoxy resin based reinforced plastic.

1. Abrade with 180 grit paper or "Scotch-Brite" Brand scrub pad (do not cut through resin into reinforcing fibers).

2. Degrease using acetone or methylethyl ketone using an unsized cheezecloth pad.

3. Air dry for two hours minimum. 


\section{" Primers}

For most applications, use of a corrosion inhibiting primer is suggested to obtain maximum bond durability in moist, corrosive environments. 3M corrosion inhibiting primers EC-3924B, EC-3960, EC-3980 and EC-3917 have all been successfully used with AF-163-2 films. Because of its characteristics which allow both spray and brush application methods, EC-3924B is normally suggested for use with AF-163-2 films. For suggested application techniques, refer to the respective primer data sheets.

\section{Primer Coverage}

For the primers noted above, the optimum mechanical property test performance with AF-163-2 will normally be found with a uniform primer coverage in the $1000-3000 \mathrm{mg} / \mathrm{m}^{2}$ range (dry weight). This is approximately 0.1 mils as measured by an isometer*. As the primer weight is increased a gradual decrease in low temperature peel strength will be found along with increasing levels of cohesive fracture in the primer layer (exception: properly controlled $180^{\circ} \mathrm{T}$.Peel does not normally show this effect). Where specific tests and required strength levels are involved, a few simple experiments with varied primer coverage will be required to establish an allowable primer coverage range. Further applications can then be controlled by correlating color or thickness standards for the acceptable range.

*Foerster Instruments Inc.

\section{iv Primer Dry}

The following cycle is suggested for these primers when used with AF-163-2 films:

Air dry: 60 minutes followed by a

Force dry: 60 minutes at 250 to $300^{\circ} \mathrm{F}$.

Normally optimum performances will be found at the higher end of the force dry temperature range when used with AF. 163-2 films.

Note: Use of these primers without a force dry is not recommended in conjunction with AF-163-2 films and is subject to very strict limitations. Consult with your $3 \mathrm{M}$ representative if further information is required.

\section{$\checkmark$ Adhesive Film Application}

Care should be taken during application to avoid contamination of the adhesive and substrates by any substance which will interfere with the wetting action of the adhesive.

\section{Layup:}

\section{A. AF-163-2U, $M$, or K Films}

1. Cut a portion of film sufficient for the assembly from the stock roll with protective liner(s) in place.

2. If the film has one protective liner, place the exposed adhesive against the substrate using the liner as a protective cover. If two liners are present, remove one and follow as above.

3. Position film and rub out all air between the adhesive and the substrate. Use of a rubber roller will facilitate this process.

4. Remove protective liner.

5. Complete assembly being careful to avoid trapping air and cure.

\section{B. AF-163-20ST Films}

OST films are designed to facilitate the removal of air from large area solid panel construction. Application of vacuum to the assembly prior to and during the initial heat cycle is normally required (see cure conditions below).

1. Cut a portion of film sufficient for the application with the liner in place.

2. Remove the protective liner and apply the high tack side of the film against the substrate (high tack side is adjacent to the liner).

3. Position the film and rub out all air between the adhesive and the substrate (use of a rubber roller will facilitate this process).

4. Complete assembly and cure. 
Product Application: (cont.)

\section{Cure Conditions \& Characteristics}

AF-163-2 films are designed to provide short cure times in the $225^{\circ} \mathrm{F}$. to $300^{\circ} \mathrm{F}$. temperature range. While performance outside this cure temperature range has not been fully investigated, limited results suggest that cure temperatures as high as $350^{\circ} \mathrm{F}$. may be used as well as longer cure times at $200^{\circ} \mathrm{F}$. $(6 \mathrm{hrs}$.) to obtain useful performance.

A. Weight Loss During Cure: Less than 1\% (AC \& S method C-273)

$\left(60 \mathrm{~min}\right.$. at $250^{\circ} \mathrm{F}$.)

B. Gel Time: The following times are typically required to convert the AF-163-2 resin system to a low strength, rubbery solid on a pre-heated stage.

\begin{tabular}{ll} 
Temperature & Gel Time \\
\hline $200^{\circ} \mathrm{F}$. & 103 minutes \\
$225^{\circ} \mathrm{F}$. & 47.5 minutes \\
$250^{\circ} \mathrm{F}$. & 20.5 minutes \\
$275^{\circ} \mathrm{F}$. & 10 minutes \\
$300^{\circ} \mathrm{F}$. & 5.5 minutes
\end{tabular}

C. Flow During Cure: (AC \& S method C-261)

The following levels are typical averages for AF-163-2 films using a cure of $235^{\circ} \mathrm{F} .-30$ minutes $-35 \mathrm{psi}-5^{\circ} \mathrm{F}$. minute.

Adhesive $\%$ Flow (area increase)

AF-163-20ST Wt. $03 \quad 225 \%$

AF-163-2K Wt. $06 \quad 350 \%$

AF-163-2M Wt. $06 \quad 400 \%$

AF-163-2K Wt. $.085 \quad 450 \%$

D. Cure Time and Temperature

1. For temperatures from $250^{\circ} \mathrm{F}$. to $300^{\circ} \mathrm{F}$, a cure time of 60 minutes at temperature is suggested.

2. For temperatures between $225^{\circ} \mathrm{F}$. and $250^{\circ} \mathrm{F}$, a cure time of 90 minutes at temperature is suggested.

Following cure, it is suggested that pressure be maintained until the assembly has been cooled to $150^{\circ} \mathrm{F}$. or below.

\section{E. Heat up rate}

Bond line temperature rise rates between $1^{\circ} \mathrm{F} . /$ minute and $20^{\circ} \mathrm{F}$./minute have been used successfully with AF-163-2 films. It must be noted that hot entry cures at $300^{\circ} \mathrm{F}$. and above can be expected to produce reduced performance due to the presence of resultant bond line porosity. 
Product Application: (cont.)

\section{F. Cure Pressure}

\section{Positive Pressure Cures}

During cure. pressure is required to keep parts in alignment and to overcome distortions and thermal expansion of the adherends. When bonding honeycomb assemblies with non-perforated core, pressure is required to overcome the thermal expansion of air in the honeycomb cells. Positive pressures between 20 and 80 psi have been used successfully with AF-163-2 film. For very small area bonds, however, pressures at the higher end of this range may produce excessive squeeze out and adhesive bond line starvation. For large solid panel constructions which are autoclave cured, application of vacuum for 15 to 20 minutes prior to application of heat and pressure is suggested to assist in removing any residual air trapped in the assembly. Normally, the vacuum is released following application of positive pressure. For problem assemblies, maintain the vacuum during the heatup cycle to about $130^{\circ} \mathrm{F}$. to further assist in providing void free bonds.

Note: When using AF-163-2OST films it is essential that these suggested vacuum application steps be included to gain the full effect of the air removal potential of the OST construction.

\section{Vacuum Curing}

AF-163-2 films can be successfully cured using vacuum cure techniques. For performance comparable to positive pressure cures, AF-163-2K films should be cured using a vacuum level in the range of 8-12 inches of mercury. Higher vacuum levels yield excessive porosity and corresponding strength reductions. AF-163-2M and OST versions have shown a high level of performance retention across the 10-25 inches of mercury vacuum level range. 


\section{Storage:}

Storage Stability - Storage at $0^{\circ} \mathrm{F}$, or below is recommended for Scotch-Weld Brand Adhesive AF-163-2 films to obtain maximum storage life.

Caution: AF-163-2 films should be permitted to thoroughly warm to room temperature before being used in order to prevent moisture condensation. (Do not open protective container prior to reaching ambient conditions).

\section{Precautionary Information:}

See Material Safety Data Sheet for precautions during use.

\section{Important Notice to Purchaser:}

All statements, technical information and recommendations contained herein are based on tests we believe to be reliable, but the accuracy or completeness thereof is not guaranteed, and the following is made in lieu of all warranties, express or implied:

Seller's and manufacturer's only obligation shall be to replace such quantity of the product proved to be defective. Neither seller nor manufacturer shall be liable for any injury, loss or damage, direct or consequential, arising out of the use or the inability to use the product. Before using, user shall determine the suitability of the product for his intended use, and user assumes all risk and liability whatsoever in connection therewith.

No statement or recommendation not contained herein shall have any force or effect unless in an agreement signed by officers of seller and manufacturer. 

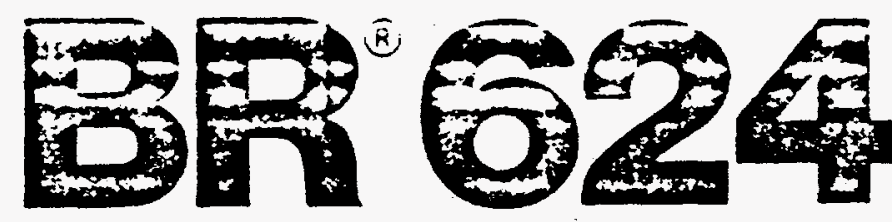

Potting Compound

BR 624 potting compound is a one-part, low.density material formulated for use in insert or edge filling of honeycomb sandwich construction. It is a thermosetting. modified epoxy system. serviceable over a temperature range of $-70^{\circ} \mathrm{F} 10350^{\circ} \mathrm{F}$ $\left(-57^{\circ} \mathrm{C}\right.$ to $\left.175^{\circ} \mathrm{C}\right)$.

8R 624 potting compound is thixotropic and cure cycles may be varied over a broad range: cure lemperatures as low as $225^{\circ} \mathrm{F}\left(105^{\circ} \mathrm{C}\right)$ and as high as $350^{\circ} \mathrm{F}\left(175^{\circ} \mathrm{C}\right)$ have been used successfully Multiple cure cycles at temperatures up to $350^{\circ} \mathrm{C}$ $\left(175^{\circ} \mathrm{C}\right)$ will not impair its use as a structural materıal.

\section{Product Description}

\section{Form}

Color

Specific gravity

Shelf life
Thixolrodic paste

Dark maroon

Approximately 0.65

Six months from date of shipment at recommended storage
Storage

Density range

(cured)

Shop ite
Store at or below $0^{\circ} \mathrm{F}\left(-18^{\circ} \mathrm{C}\right)$

37 to $47 \mathrm{ib}^{\mathrm{fift} \mathrm{f}^{2}}$

(.592 to $.752 \mathrm{gmicc})$

30 days below $75^{\circ} \mathrm{F}\left(24^{\circ} \mathrm{C}\right)$

\section{Curing Procedure}

BR 624 potting compound may be applied with caulking guns or spatula-like tools Warming to temperatures up to $110^{\circ} \mathrm{F}\left(43^{\circ} \mathrm{C}\right)$ will tacilitate filling of honevcomb cells

The recommericec cure cyce is 30 :0 60 minutes

heat-up to $250^{\circ} \mathrm{F}\left(120^{\circ} \mathrm{C}\right) ; 60$ minutes hold at $250^{\circ}$ $\pm 5^{\circ} \mathrm{F}\left(120^{\circ} \pm 3^{\circ} \mathrm{C}\right)$. If slight expansion is objectionable, restraint during cure is suggested. After cure. BR 624 can be sanded or machined. as シニ゙こ 
Table I

Typical Strength Properties of

BR 624 Potting Compound

\begin{tabular}{|c|c|c|}
\hline $\begin{array}{c}\text { Density } \\
\text { lb/cu ft }(g \mathrm{~m} / \mathrm{cc})\end{array}$ & $\begin{array}{c}\text { Compressive Strength } \\
\text { at } 0.2 \% \text { offset } \\
\text { psi (MPa) }\end{array}$ & $\begin{array}{c}\text { Testing Temperature } \\
{ }^{\circ} \mathrm{F}\left({ }^{\circ} \mathrm{C}\right)\end{array}$ \\
\hline $\begin{array}{l}43.12(.69) \\
47.00(.75) \\
45.65(73) \\
42.27(.68) \\
46.31(.74) \\
46.80(.75)\end{array}$ & $\begin{array}{r}10.463(73.16) \\
10.800(7448) \\
9.850(6793) \\
5.428(3743) \\
3.800(2621) \\
4.435(30.59)\end{array}$ & $\begin{array}{r}75(24) \\
75(24) \\
75(24) \\
180(82) \\
180(82) \\
180(82)\end{array}$ \\
\hline
\end{tabular}

Material

Core-8.1.1/8.002.5052N, $1^{*} \mathrm{t}(3.175 \mathrm{~mm} \cdot .050 \mathrm{~mm} \cdot 5052 \mathrm{~N}, 25.4 \mathrm{mmt})$

Cure Cycle

BR 624 potting compound troweled into core. takıng care not to entrap air bubbles

Press rate to $250^{\circ} \mathrm{F}\left(120^{\circ} \mathrm{C}\right)$ : 60 minutes at $250^{\circ} \mathrm{F}\left(120^{\circ} \mathrm{C}\right)$ :

Restrained under 40 psı ( $276 \mathrm{MPa}$ ).

Specimens machined to $1.1 / 2$ inches $(38.10 \mathrm{~mm})$ diameler

Table II

Core Shear as a Function of Splicing Core with BR 624 Potting Compound

\begin{tabular}{|l|c|cc|}
\hline \multicolumn{1}{|c|}{ Splice Material } & Variable & $\begin{array}{c}\text { R.T. Flexure } \\
\text { Load.ib (Load.N) }\end{array}$ & Type Failure \\
\hline None & Control & $3050(13.567)$ & Core shear \\
& & $3020(13.434)$ & Core shear \\
BR 624 potting compound & Core spliced & $3030(13.480)$ & Core shear \\
& & $2940(13.078)$ & Core shear \\
\hline
\end{tabular}

Materiais Faces- $064^{*}(1.63 \mathrm{~mm}) 2024 . T 3$ Alclad

Core-7.9-1/4.004.5052N. 1/2" I (6.25 mm-102 mm-5052N. $12.7 \mathrm{mmt})$

Cure Cycle $\quad 60$ minutes to $225^{\circ} \mathrm{F}\left(105^{\circ} \mathrm{C}\right)$ : 90 minutes at $225^{\circ} \mathrm{F}\left(105^{\circ} \mathrm{C}\right)$ :

40 psi (.276 MPa)

Table III

Compressive Strength vs. Heat Aging at $350^{\circ} \mathrm{F}\left(175^{\circ} \mathrm{C}\right)$

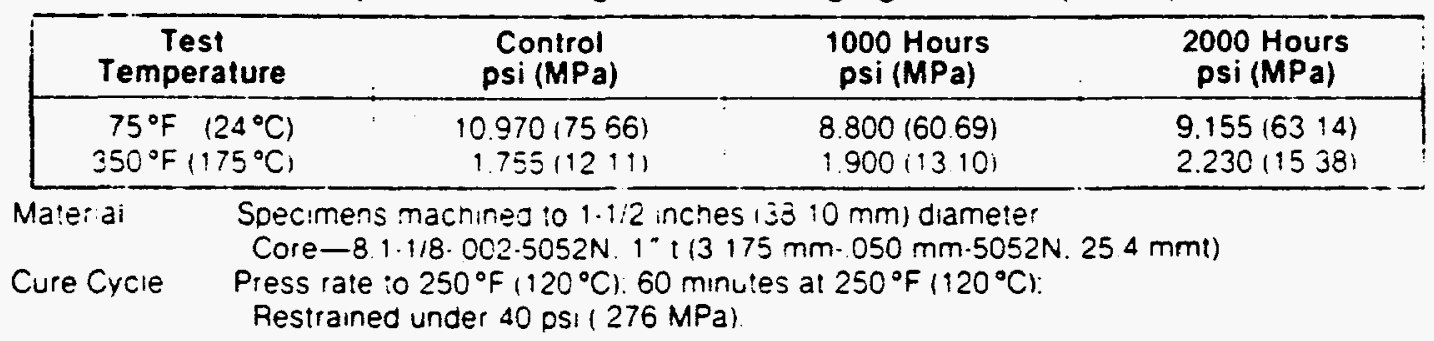

\section{Warning}

Contains an epoxy resin. May cause allergic skin reaction. Avoid prolonged or repeated contact with skin.

Wash thoroughly after handling.

\section{First Aid}

In case of contact, immediately wash skin with soap and plenty of water.

\section{Ventilation Required}

Use mechanical exhaust ventilation when heat curing resin system.

\section{Detailed Handling Instructions}

Refer to Material Safety Data Sheets and product labels.

\section{Important Notice}

The in'ormat:on and statements neren are believed to be re'able but are not to be construed as a wareantv or representation ior which we ajsume ega: esponsibury. Ujers srou durdertake suificier: ventica: on and tesing to determ!ne the suitab!ly 'or the'r own particular OurDose of any information or products reierred to nerein. NO WARRANTY OF FITNESS FOR A PARTICULAR PURPOSE IS MADE. Nothing here in is to be taken as permission, inducement or recommendation to practice any patented invention without a license. 
Nylon

\section{COLOREO POL VUAETHANE COATED NYON FABRIC}

Tear-resistant nylon with tough polyurethane coating makes great truck covers, outdoor curtains, equtpment covers, and canoples. Fabric is lightweight. flexibie in cold temperatures. and has high resistance to abrasion. Resists oils solvents. chemicals, mildew, and rot. Will not stretch or shrink. Weight is 13 ounces per square yard. Thickness is $.025^{\circ}$

Width is $8114^{\circ}$ and maximum continuous length ls $150 \mathrm{yds}$

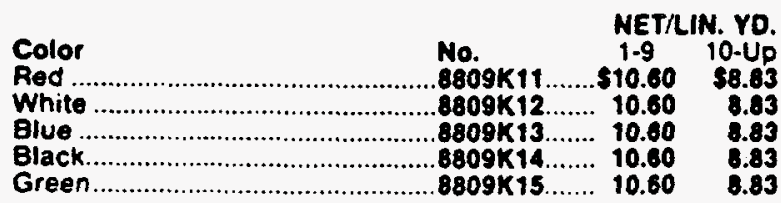

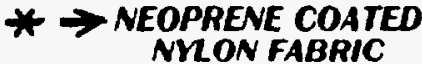

A good, strong, all-apound fabple for asphalt covers, equipment covers, and truck covers. Also makes a good tiexible duct connector. The neoprene coating gives excellent resistance to deterioration caused by exposure to asphalt. oils. solvents, gases, grease. mildew. and ultraviolet rays. The heavy fabric resists tearing and punching

Fabric is easy to handle at low lemperatures. Furnished with black neoprene coating on both sides or with black neoprene on one side and alu. minum on the other side.

Weight is 16 ounces per square yard. Thickness is $025^{\circ}$

Width le $60^{\circ}$ and maximum continuous length is $100 \mathrm{yds}$.

Description

Neoprene Both Sides

Neoprene/Aluminum
NET/LIN. YD.

$\begin{array}{lrr}\text { No. } & 1.9 & 10 . \text { Up } \\ \text { 881tK11......\$12.94 } & \$ 10.83\end{array}$

(8)11K12 $13.72 \quad 11.43$

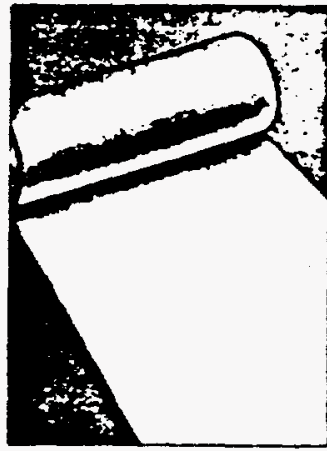

\section{LGGHT WEIGHT COLORED}

VNY LAMINATED NMON FABRIC

flexible fabric is excellent for llght duty tarpeulins. windscreens, bags, sir structure liners, oprons, and vests. Fabric resists abrasion. weather, water, and rot Has high tensile strength and resists tearing

Fabric conforms to MIL-C-43006F Type 2 and is fire retardant. Weight is 10 ounces per square yard. Thickness is $.012^{*}$. Width is $54^{*}$ and maximum continuous longth is 100 yds.

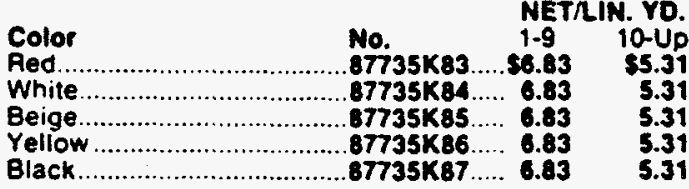

\section{MEDICM WEIGHT COLORED}

VNY LAMINATED NYLON FABRIC

Oll-resiatant fabric is ideal for indoor and outdoor curtains. quipment and lloor covers, spray booth curtains, draft protection, and privacy barsiers.

Fabric resists acids alkalies. and mildew and is tear and abrasion resistant. Nol recommended for use as truck covers. Fabric is flame retardant. Weight is 13 ounces per square yard. Thickness is $.022^{*}$. Width is $60^{\circ}$ and maximum continuous length is 100 yords.

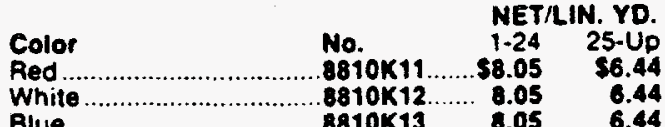

\section{Polyester}

\section{MEDIUM WEIGHT COLORED VINYL LAMINATEO POLVESTER FABRIC}

Whether it's inside or out. side, you've got it covered with this vinyl laminated polyester tabric. Ideal lor tarpaulins. windscreens, and drop clolns. Excellent as outdoor prolective covers for equipment and vehi. cles Fabric nas nigh tear and tensile strength. Resists abrasion and rot. Material is fire retardant.

Olive drab tebric is a little heavier. with a camoullage pattern. Use for equipment bags. windscreens. and coverings.

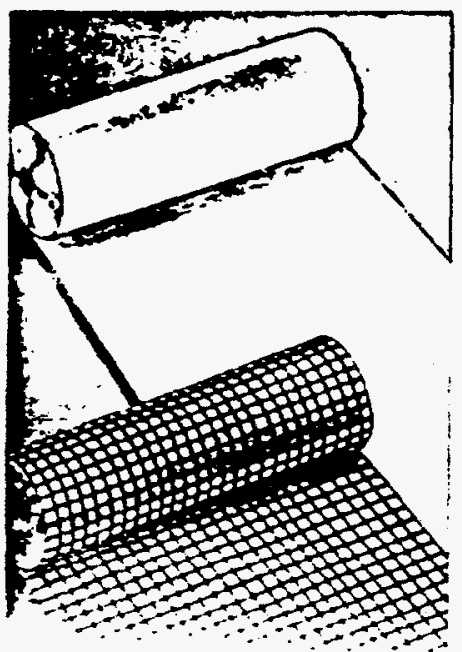

Color

No.

NET/LIN. YD.

14 OZ/SO. YO. $-62 \%$ WIOE ANO $017^{\circ}$ THICK

Maximum continuous length is 75 yards

Red ............................87615K73 ....\$8.03

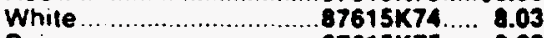

Beige ………..............87615K75.... 8.03

Yellow $87615 \times 76.8 .03$

Black ...............................87615K77..... 8.03

Orange ............................87615K78.... 8.03

18 0Z/SO. YD. - 54" WIDE ANO .021" THICK Maximum continuous length is 50 yards Olive Drab Camoutlage ...87615K88....\$9.90

$\$ 7.92$

6.24

6.24

6.24

6.24
Cloth roflects heat to whore it's needed... saves on energy costs.

Use this unique fabric for insulating curtains. orop ceilings. thermal barriers. reflective covers and tarpaulins.

Fabric is made of aluminum toil lamirated to polyester. inen laminated to vinyl Fabric is waterproof
Here's a super lightwoight. ses-ihrough mosh fabric that still has plenty of strength for outdoor use. Excellent for pedestrian Iralfic bartiers. divider curtains. truck covers. wind. screens. safety apparel. utility bags. and landscaping tie-downs The material has good dimensional stabilty and is abrasion resistant It 5 ? 20 es:

\section{HEAW WESHT COLORED VNYL COATED POLYESTER FABRIC}

This excellent general purpose outdoor covering is ideal tor tarps, curtains, and equipment covers. Waterprool material will nol rot. Fabric is not flame retarcant. Weight is 18 oz. per square yard. Thickness is $024^{2}$

Widh is $61^{\circ}$ and moximum continuous length is 100 yerds.

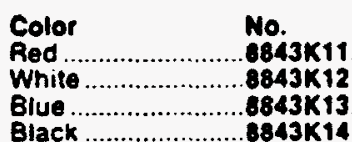

NET LIN NOP.

$1.9 \quad 10.4 p$

$\$ 9.98 \quad \$ 8.32$

$9.98 \quad 8.32$

$9.98-8.32$

\section{A. ALCIMINIZED VINYL LAMINATED POLYESTER FABRIC}

and resistant to abrasion and rot.

Use indoors as well as outdoors in humid and damp environments. Color of non-aluminum side is white. Width is $54^{\circ}$.

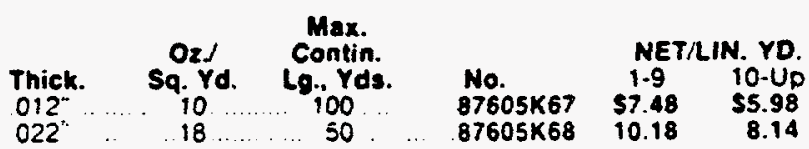

\section{B. OPEN MESH COLOREO VINYL COATED POLVESTER FABRIC}

Thickness is $020^{\circ}$, except camouflage. which is $.014^{\prime \prime}$ thick. Width is $62^{\circ}$ and maximum continuous length is 100 yards.

\begin{tabular}{|c|c|c|c|}
\hline & & NET & IN. YO \\
\hline $\begin{array}{l}\text { Colors } \\
\text { Red } \\
\text { Write } \\
=\end{array}$ & $\begin{array}{l}\text { No. } \\
87655 \mathrm{Kg3} \\
87655 \mathrm{~K} 94 \\
87 E==\times 05\end{array}$ & $\begin{array}{r}1.9 \\
55.31 \\
5.31 \\
531\end{array}$ & $\begin{array}{r}10-40 \\
54.13 \\
4.13 \\
4.1 ?\end{array}$ \\
\hline
\end{tabular}




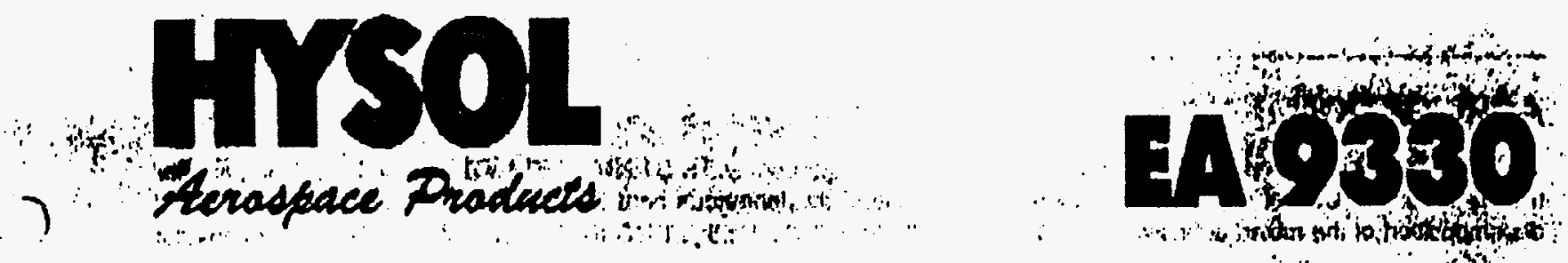

\section{STRUGURAL ADHESIVES}

\section{DESCRIPTION}

Hyeof EA 2380 is a two component pasto adhodive which is easily mixed and has high poel strength. This room femporature oure syetem has pood environmental realstance and bonds to a varioty of substratea.

\section{FEATURES}

- Two Component

- Room Temperalure Cure
- Tolerant of Bondline Thickness Varlations

- High Peol Strongth

- Excollent Environmental Resistanco

\section{UNCURED ADHESIVE PROPERTIES}

\begin{tabular}{|c|c|c|c|}
\hline & Part A & Part B & Mixed \\
\hline Color & Cruam & Anber & Crean \\
\hline $\begin{array}{l}\text { Visconlity } 77^{\circ} \mathrm{F} \\
\text { Brooldiold, HBT }\end{array}$ & $\begin{array}{c}2000 \text { Polve } \\
\text { Spoll } 8010 \text { RPM }\end{array}$ & $\begin{array}{c}\text { 15 Polse } \\
\text { Epdl } 1 \text { O } 20 \text { RPM }\end{array}$ & \\
\hline $\begin{array}{l}\text { Vacoity, } 28^{\circ} \mathrm{O} \\
\text { Brooldidd, HBT }\end{array}$ & $\begin{array}{c}200 \text { Pas } \\
\text { Spdl } 6 \text { \& } 1.08 \mathrm{rad} / \mathrm{cec}\end{array}$ & $\begin{array}{l}1.5 \text { Par } \\
\text { Spdl } 1 \text { C } 2.09 \text { radrece }\end{array}$ & \\
\hline Density (g/mi) & 1.30 & 1.03 & 1.18 \\
\hline 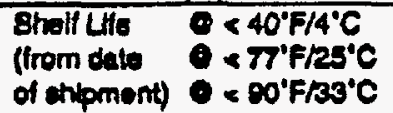 & $\begin{array}{l}1 \text { yesp } \\
1 \text { year } \\
1 \text { year }\end{array}$ & $\begin{array}{l}1 \text { year } \\
1 \text { yoar } \\
1 \text { yoar }\end{array}$ & \\
\hline
\end{tabular}

\section{HANDLING}

Mixing - This produst requires mixing two components together juat prlor to appllcatton to the parts to be bonded. Complete mixing beceseary. The temperature of the ceparate components prior to mixing is not critical, but should be clone to room tomporawn ( $7^{\circ}$ Frst $\left.\mathrm{C}\right)$.

$\frac{\text { Mix Retlo }}{\text { By Weloht }} \quad \frac{\text { Part A }}{100} \quad \frac{\text { Part }}{83}$

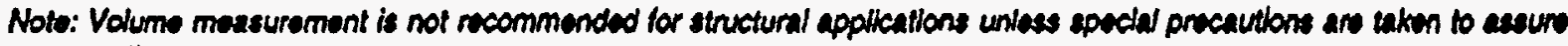
propor ration.

Pot Lito (100 gm maes) Method . A5TM 02471 in water bath. 


\section{APPLICATION}

Mixing - Combine Pan A and Part 8 in the correct ratto and mbx thoroughly. THIS IS IMPORTANTI Hant buldup during or atlor

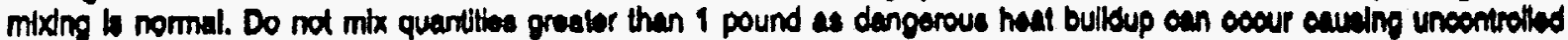
decompostion of the mixed adhestw. TOXIC FUME8 CAN OCCUR, RESULTING IN PERSONAL INUURY. MIXIn. Emaller quantives will minimize the hoal bulldup.

Applying - Bonding surtuces chould be clean, dry and properly prepared. For optimum surtace preparatlon consult ths Hyal Surface Preparation Gubde. The bonded parts should be held in conted until the achestve is eet. Handing elrength lor this adhestve wit occur in 20 hours at $77^{\circ} \mathrm{F} / 25^{\circ} \mathrm{C}$, efter which the suppont looling or preseure used during cure may be removed. 81 nce full bond strength has not yot been atlained, load application atould be small at this time.

Curing - Hysol EA 9330 may be cured for 5.7 days at T7F/25'C to schleve normal performance. Accelorated cures up to

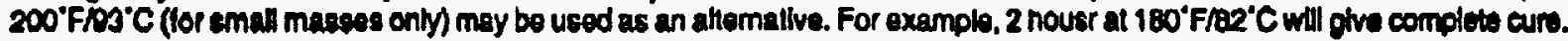

Cleanup - it is important to nomove excess adhestve from the work area and applicatton equipment botore thrardenw. Denatured acohol and muny common industrial solvents are cultable for removing unoured adhestre. Consult with your wpplior's information pertulning to the exte and proper use of colvents.

\section{BOND STRENGTH PERFORMANCE}

Tensil Lap shear Otrongth

Tenslle lap shear strength lested per ASTM D 1002 after curing as shown bolow. Adherends are 2024-TS ded aluminum ineated with chromlo nold toh.

Tent Tampenture, "Fre

Typleal Rosult (PEMAPo)

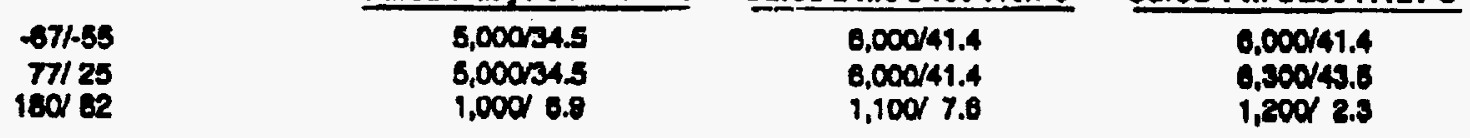

Effect of surfac Praparation on Tenslle Lap Shoar at T7F/25'C. Substrates are 2024-T3 clad aluminum:

Ourtace Proparation

MEK MPOS

Gand Elasted

Wire Buahed

Aftor Expoeure to tho

followine cenditlone:

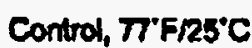

77FRs'C Water-30 dayo

$120^{\circ} \mathrm{F} / 40^{\circ} \mathrm{C}-100 \times \mathrm{KAH}-30$ days

Antitloing F1.7 daye

Hydraullo Oll-7 deye

JPa Puol-7 days

8alt 8pray-105'F/41'C-30 daye

Bkydrol $300-7$ daye

TT-8735-7 day
$4,100 \mathrm{pB} 3$

Cursd 7 daysertrpro'c

$5,500 \times 37.9$

$3,70025.5$

$4,300 / 29.7$

$5,500 / 37.0$

$5,80038.6$

$5,800 / 40.0$

$3,50024.1$

$5,700 / 39.9$

$6,300 / 80.6$

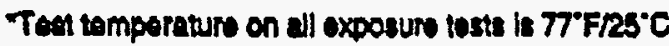

Curnd 2 hrse $180^{\circ} / 142^{\circ} \mathrm{C}$

$4,300 / 29.7$
$5.100 / 35.2$
$4,500 / 31.0$

Cured 1 hre2s0"Fn21"C

$5,60038.0$

$6,200 / 25.0$

$6,30038.6$

Cured 2 hree 180'F/82'C Cured I hre2s0'F/21'C

$6,300443.5$

$4,400130.4$

$4.100 / 28.3$

$6,200 \times 42.8$

$0,400144.1$

0.100142 .1

$3,50024.1$

$6,100142.1$

$5,500 / 40.7$
$0,600 \times 44.8$

$3,00028.0$

$8,000 / 41.4$

$0.000 \times 4.8$

6,000145.8

$3,700 \mathrm{ps} .5$

$6.300 / 45.8$

8.000140 .0
$4,400150.3$

Effect of Primer on Tenallo Lap Bhear propertios:

Textemporcturo, "Fre

\begin{tabular}{rc}
$-07 / .53$ & Non \\
$77 / 25$ & $5,300 / 36.6$ \\
$180 / 82$ & $5,300 / 37.9$ \\
\hline & $1,000 / 6.9$
\end{tabular}

Prtmee

EA $8202(A)$

5.60038 .6

$5,100336.2$

$1,500 / 10.3$
A eave)

5,4001372

$8,600 / 38.6$

$1,000 / 13,1$

Primer Thlekness: $\quad 0.3 \mathrm{mill} / .008 \mathrm{~mm}$

Primer Flach: $\quad 1 \mathrm{hreT} / \mathrm{F} / 26^{\prime} \mathrm{C}$

Pimer Buka: (A) 1 hre250'F/121' C

(B) 1 hre328. $/ 1703^{\circ} \mathrm{C}$

Adheulve Cure: 7 daye $17^{\circ} \mathrm{P} / 2 \mathrm{~s}^{\circ} \mathrm{C}$ 
NOU-13-'94 FRI 13:B7 ID:DEXTER RERO PITTS TEL NO:5:0 458 8030

\section{EA $93303 \% 4$}

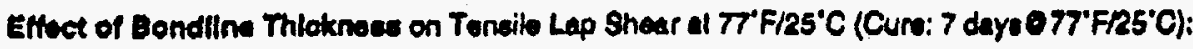

\begin{tabular}{|c|c|}
\hline Bondlin Thieknows (Mile/mm) & Typloal Rooult (PsMNPa) \\
\hline $\begin{array}{r}10.10 \\
100.25 \\
2010.81 \\
3010.78 \\
10 / 1.02 \\
80 / 1.27\end{array}$ & $\begin{array}{l}5,20035.9 \\
5,00034.5 \\
4,600131.0 \\
4,60031.0 \\
4,40030.3 \\
4,10028.3\end{array}$ \\
\hline
\end{tabular}

Peel Strenoth

T Pael atrangth tagted per ASTM 01876 after cunng as shown bolow. Adhorends are 2024 T3 clad aluminum trattod with chromke add otoh.

Tost Temporature, PrC

$77 / 25$

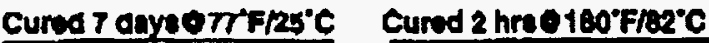
$35 / 155$

48204
Typleal Reculto (PLWLM)

Cured 1 hre2so'rhz1'C 4.804

Bell Poel Strength

Teet Temporazune, "FFO

7725

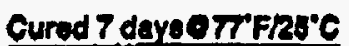
$92 / 407$
Typleal Howulis (PLWLN)

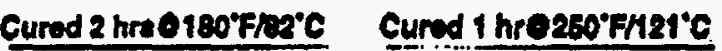
87/428 10.4409

Motal to Motal Climbing Drum Peal

Test Tomperature, Fre

Typlad Rowults (PLWLM)

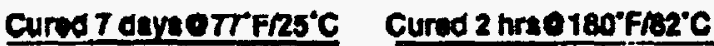

77/26 58/257

90/43:

Cured 1 hre 260"Fn21'C 92/407

Eorvice Temporature

Sorvice temperature is defined as that femperature at which this adhastve stll retalins 1000 PSV6.8 MPa using teat mathod ASTM D 1002 and is $180^{\circ} \mathrm{F} / 22^{\circ} \mathrm{C}$.

\section{Bulk Resin Propertlea}

Tenslle Propertes - teated using 0.126 Inctv0.317an castings per ASTM D 838. Specimens were cured 7 ouye ar $77^{\circ} \mathrm{F} / 25^{\circ} \mathrm{C}$.

Tenalie Strungth, PSA $77^{\circ} \mathrm{F} / 25^{\circ} \mathrm{C}$

Tenalle Modulue, PSI $97^{\circ}$ FR'S'C

Elongaton at Break, $\% \neq T^{\circ} F B^{\circ} \mathrm{C}$

Barcol Hardness $97^{\prime \prime}$ FRE $^{\circ} \mathrm{C}$, 1935 impreseor

T.

Shour Modulus KSIMPe

Polseon's Ratio

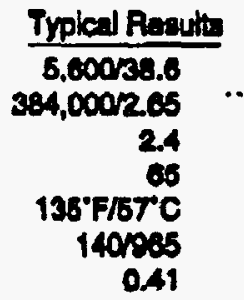

Comproashy Propertied - tosted Ueing 0.6 Inoh/ $27 \mathrm{~cm}$ castings per ASTM 0695.

Compresstve Strongth, PSI 9 TTFMPa $02^{\circ} \mathrm{C}$

Compressive Modulus, PSI TTFKPa $\odot$ 25'C

$7,700158.1$

$253,000 / 1.74$

Electrical Properties - tested per ASTM D 148, D 150.

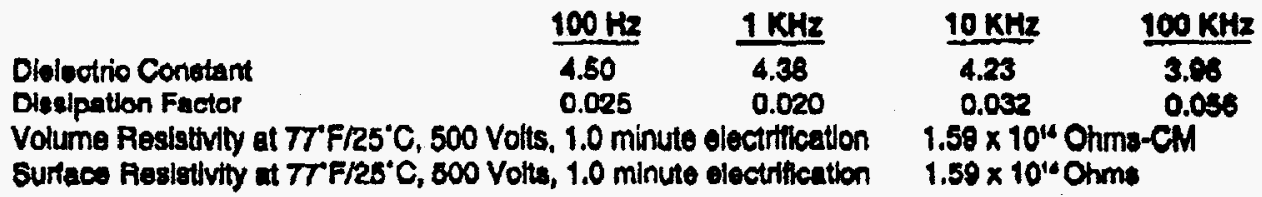




\section{EA $9330 \quad 4 \% 4$}

\section{HANDLING PRECAUTIONS}

Eotore uaing this product, read tho Material Safety Data Sheots carstully.

For inductital use only.

Coneral:

Use these products with adequate ventliation. Do not get in eyes of on skin. Avold brealhing the vapors. Wash theroughly with soap and wator ather handing. Emply contalners retaln product raslous and vapors so obey all precautions when handling ompty containur.

PART A

WARNINGI The uncursdachesive causes eye intlation and maycauns ekin Imitation or allorglo dermattis. Containa epoxy ratine.

PART D

DANteral Causes severs skin and eye bumo. Vapors may be iritating to the respiratory tract.

\section{AVAILABILITY}

This Hyeol Aerospaco Product ls avallable from Dexter Aerospace Matertals Division, 2850 Wilow Pase Roed, P.O. Box 312. Pitlabuit, CA 24585-0031. Tolephone 510/468-6000. FAX 510/458-8050. 